\title{
CESIUM IN THE SAVANNAH RIVER SITE ENVIRONMENT ${ }^{(U)}$
}

W. H. Carlton

L. R. Bauer

A. G. Evans

L. A. Geary

C. E. Murphy, Jr.

J. E. Pinder

R. N. Strom

Approved by: $\quad$ A. L. Boni, Manager

Environmental Technology Section

Savannah River Laboratory

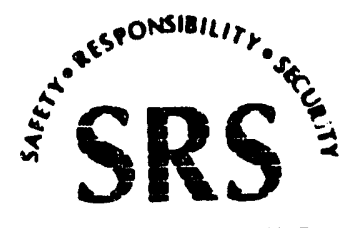




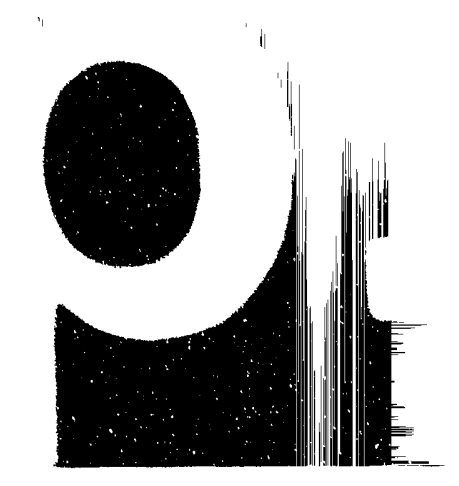

\section{Contents}

Executive Summary

Chapter 1.

Introduction

Radiocesium in the Global Environment 1-1

Radiocesium in Regional Environments 1-2

Radiocesium in the SRS Environment 1-3

References 1-4

Chapter 2.

SRS Operations Involving Radiocesium

Origin of Radiocesium at SRS 2-1

Irradiation In Production Reactors 2-1

Other Sources Because of SRS Operations 2-1

SRS Test Reactors 2.1

Spontaneous Fission $\quad \mathbf{2 . 2}$

Neutron Activation Analysis $\quad 2.3$

Materials Originating Offsite $\quad \mathbf{2 - 3}$

\section{Disposition of Radiocesium at SRS 2-4}

Radiocesium in Fuel and Targets Irradiated in Production Reactors $2-4$

Radiocesium in Certain Fuels Irradiated Offsite 2-5

Radiocesium in Fuel and Targets Irradiated in Test Reactors 2-5

Radiocesium From Spontaneous Fission 2-5

Neutron Activation Analysis Samples 2-5

Commercially Purchased Radiocesium 2-6

Global Fallout Radiocesium 2-6 
References 2-7

Chapter 3.

Releases and Stored Inventories of Radiocesium at $S R S$

Reactor Facilities 3-1

Facility Operations 3-1

Pathways for Release 3-2

Emission Control 3-3

Release Monitoring 3-3

History of Measured Releases 3-4
C Reactor 3-4
K Reactor 3-4
L Reactor 3-5
P Reactor 3.6
R Reactor $3-6$
Summary of Reactor Releases $\quad 3.7$

Separations and Liquid Waste Facilities 3-8

Facility Operations 3-8

Pathways for Release 3-8

Release Monitoring 3-9

History of Measured Releases 3-9

F-Area Separations 3-9

H-Area Separations 3-10

Waste Tank Farms 3-12

Summary of Separations and Liquid Waste Facilities $3-13$

Solid Waste Disposal Facility 3-14

Savannah River Laboratory 3-15

Other Facilities 3-16

Summary 3-17

References 3-18 
Chapter 4. Radiocesium Concentration and Transport Mechanisms

Atmospheric Concentrations and Transport 4-1

Concentration of ${ }^{137} \mathrm{Cs}$ in Air $\quad 4-1$

Deposition of ${ }^{137} \mathrm{Cs}$ in Rainwater 4-3

Surface Water Transport 4-4

Surface Waters on the Savannah River Site 4-4

Lower Three Runs Creek 4-4

Upper Three Runs Creek 45

Steel Creek 45

Four Mile Creek 46

Pen Branch 46

Site Stream Summary 46

Savannah River 4-6

Groundwater Concentrations and Transport 4-7

SRS Groundwater System 4-7

Geochemistry of Cesium 4-10

Isotopes ${ }^{134} \mathrm{Cs}$ and ${ }^{137} \mathrm{Cs}$ in SRS Groundwater 4-10

Solid Waste Disposal Facility 410

General Separations Area Seepage Basins 410

The H-Area Seepage Basins 411

SRL Seepage Basins 411

CMX/TNX Seepage Basins 412

Reactor Areas Seepage Basins 412

Ford Building Seepage Basin 413

General Observations 4-13

Cesium in Wildlife 4-14

References 4-19

Chapter 5.

Environmental Research on ${ }^{137} \mathrm{Cs}$ by Savannah

River Ecology Laboratory 5-0

SREL Research in Steel Creek 5-1 
Uptake of ${ }^{137} \mathrm{Cs}$ by Plants 5-1

Concentrations of ${ }^{137} \mathrm{Cs}$ in Animals 5-2

Declining ${ }^{137} \mathrm{Cs}$ Concentrations in Steel Creek Biota 5-2

SREL Research in the PAR Pond/Pond B System 5-3

Remobilization of ${ }^{137} \mathrm{Cs}$ from Sediments 5-3

Behavior of ${ }^{137} \mathrm{Cs}$ in Pond Foodchains $5-3$

Summary 5-5

References 5-6

Chapter 6.

Assessment of Dose/Risk from SRS Radiocesium Releases 6-0

Relationship of Dose to Risk and Health Effects 6-1

lonizing Radiation 6-1

Cancer Risk Estimates 6-1

Radiocesium Exposure and Dose to Man 6-2

Distribution and Retention of Cesium in the Human Body 6-2

Cesium Dosimetry 6-2

Models of Radiocesium Transport and Dose 6-3

Modeling Atmospheric Dispersion of Radioactive Releases 6-3 MAXIGASP $6-4$ POPGASP 6-4

Modeling Doses from Liquid Releases 6-5

Validation of Transport Models Using Monitoring Data 6-6

Atmospheric Releases 6-6

Liquid Releases 6-6

Impact of SRS Radiocesium Releases on the Offsite Population 6-7

Doses from Atmospheric Releases 6-7

Doses from Liquid Releases $\quad 6-7$ 
Comparisons of Radiocesium Doses Near SRS with Applicable Regulations 6-9

Atmospheric Releases 6-9

Liquid Releases 6-9

Summary of Dosimetric Impacts 6-10

References 6-16

Appendix 1.

Physical Properties of Cesium A1-1

Appendix 2.

Environmental Monitoring A2-0

Air $\mathbf{A 2 - 1}$

Rainwater A2-3

Surface Water A2-4

Effluent Outfalls A2-4

Site Streams A2-4

Savannah River A2-4

Groundwater A2-6

Other Environmental Matrices A2-7

Soil A2-7

Food A2-7

Vegetation A2-7

Wildlife A2-7

Fish A2.7

Deer A2-8

Ducks A2-8

Fur Bearers A2-8 


\section{Executive Summary}

Cesium in the Savannah River Site Environment is published as a part of the Radiological Assessment Program (RAP). It is the fourth in a series of eight documents on individual radioisotopes released to the environment as a result of Savannah River Site (SRS) operations. The earlier documents describe the environmental consequences of tritium, iodine, and uranium. Documents on plutonium, strontium, carbon, and technetium will be published in the future. These are dynamic documents and current plans call for revising and updating each one on a two-year schedule.

Radiocesium exists in the environment as a result of above-ground nuclear weapons tests, the Chernobyl accident, the destruction of satellite Cosmos 954, small releases from reactors and reprocessing plants, and the operation of industrial, medical, and educational facilities.

Radiocesium has been produced at SRS during the operation of five production reactors. Several hundred curies of ${ }^{137} \mathrm{Cs}$ was released into streams in the late 50 s and 60 s from leaking fuel elements. Smaller quantities were released from the fuel reprocessing operations. About $1400 \mathrm{Ci} \mathrm{of}{ }^{17} \mathrm{Cs}$ was released to seepage basins where it was tightly bound by clay in the soil. A much smaller quantity, about four $\mathrm{Ci}$, was released to the atmosphere.

Radiocesium concentration and transport mechanisms for atmospheric, surface water, and groundwater have been extensively studied by Savannah River Technology Center (SRTC) and ecological mechanisms have been studied by Savannah River Ecology Laboratory (SREL).

The overall radiological impact of SRS releases on the offsite maximum individual can be characterized by total doses of $0.33 \mathrm{mrem}$ (atmospheric) and $60 \mathrm{mrem}$ (liquid), compared with a dose of 12,960 mrem from non-SRS sources during the same period of time. Isotope ${ }^{17} \mathrm{Cs}$ releases have resulted in a negligible risk to the environment and the population it supports. 


\section{Chapter 1.}

Cesium is an essential element in human nutrition. Manmade radioactive isotopes of cesium, if introduced into the global and regional environments, will eventually reach humans via the food chain. Thus, manmade radioactive isotopes of cesium may contribute to the radiation dose that humans receive from all sources. 


\section{Radiocesium in the Global Environment}

Radioactive isotopes of cesium exist in nature at minute levels and are collectively known as radiocesium. A natural mechanism for radiocesium production is fission of naturally occurring uranium and thorium. Such fission occurs either by spontaneous fission decay or by neutrons in nature inducing fission. Radiocesium produced by this mechanism is primarily localized to the ore deposits containing uranium and thorium.

Manmade sources that contribute radiocesium to the global environment are nuclear reactor operations and aboveground nuclear weapons tests. Nuclear weapons testing has been the most significant manmade source of radiocesium in the global environment. Above-ground testing has introduced about $3.5 \times 10^{7}$ curies of ${ }^{137} \mathrm{Cs}$ to the atmosphere, much of which has deposited on the earth as fallout, both on a regional scale and a global scale (Eisenbud, 1987a). Since the mid sixties, when the USA and USSR stopped aboveground testing, radiocesium concentrations in the atmosphere have decreased dramatically because of fallout.
The other manmade source that contributes radiocesium to the global environment is nuclear reactor operations. Ideally, all of the radiocesium produced in nuclear power reactors is contained in the fuel until reprocessing occurs. However, under accident conditions, radiocesium can be released to the global environment, as exemplified by twr. widely publicized accidents, the satellite Cosmos 954 in 1978 and the Chemobyl nuclear reactor accident in 1986. USSR's satellite Cosmos 954 was powered by a nuclear reactor and estimated to contain 86 curies of ${ }^{137} \mathrm{Cs}$ at reentry into the atmosphere where it disintegrated (Eisenbud, 1987b).

The Chernobyl accident in the USSR released $1 \times 10^{6}$ curies of ${ }^{13} \mathrm{Cs}$ and $5 \times 10^{5}$ curies of ${ }^{134} \mathrm{Cs}$ to the environment (Legasov et al., 1987). Accident conditions were severe enough to inject some radiocesium into high altitudes and distribute globally. However, most of the radiocesium was deposited as regional fallout in Europe. 


\section{Radiocesium in Regional Environments}

Manmade sources that contribute radiocesium to regional environments are nuclear weapons tests, nuclear reactor operations, industrial/medical/educational facilities, and nuclear fuel reprocessing operations.

Above-ground nuclear weapons tests produce regional and global fallout. Radiocesium could enter the atmosphere and regional environments if an underground test were to vent.

The routine operation of experimental, research, power, and production nuclear reactors has released small quantities of radiocesium to regional environments. Under accident conditions, radiocesium has been released to regional environments at times.

The least significant releases of radiocesium to local environments are from industrial/medical/educational facilities that produce, transport, or use specific cesium radioisotopes for testing purposes.
Nuclear fuel reprocessing operations have been the most significant localized source of radiocesium. Reprocessing facilities are located in several countries worldwide. Reprocessing consists of chemical separation of materials that have been irradiated in experimental, research, power, and production reactors. As a result of the chemical separations process, the radiocesium content of irradiated materials can be released to the environment through aqueous waste streams or stack gases.

An unusual and distressing release of ${ }^{17} \mathrm{Cs}$ occurred in 1987 in Goiania, Brazil. Junk dealers dismantled an abandoned teletherapy unit, and broke open the sealed sovirce containing $1375 \mathrm{Ci}$ of soluble cesium chloride (Brandao-Mello, 1991). An area of less than one square kilometer was highly contaminated (Lipsztein, 1991). Approximately 50 individuals showed symptoms of extemal and internal irradiation and 4 died. 


\section{Radiocesium in the SRS Environment}

Numerous radioactive isotopes of cesium are made in the fuel and targets of the production reactors at SRS. Most of the isotopes are short-lived and decay to insignificant activity levels during the time interval between end of irradiation and commencement of reprocessing by chemical separations at SRS.

The radiological properties of the 14 radioactive isotopes of cesium, which are in use or produced at SRS, are tabulated in
Appendix 1, Table A1-1. Only two isotopes, ${ }^{137} \mathrm{Cs}$ with a half-life of 30 years, and ${ }^{134} \mathrm{Cs}$ with a half-life of two years, are significant for purposes of radiation exposure in the environment at SRS and the vicinity. Over the 34-year operating history of SRS, about 1900 curies of ${ }^{137} \mathrm{Cs}$ and 12 curies of ${ }^{134} \mathrm{Cs}$ have been released to the environment (Cummins, 1991). Most has remained on the Savannah River Site. 


\section{References}

Brandao-Mello, C. E., et al., "Clinical and Hematological As, ects of Cs-137: The Goiania Radiation Accident", Health Physics 60:31.

Cummins, C. L., C. S. Hetrick, and D. K. Martin, 1991, "Radioactive Releases at the Savannah River Site 1954-1989", WSRC-RP-91-684, Westinghouse Savannah River Company, Aiken, SC.

Eisenbud, M., 1987a. "Environmental Radioactivity", Academic Press, pp 272 and 280.
Eisenbud, M., 1987b, "Environmental Radioactivity", Academic Press, p 367.

Legasov, V. A., et al., 1987, "Information on the Accident at the Chernobyl Nuclear Power Station and its Consequences Prepared for LAEA", Soviet Atomic Energy (English Translation) 61: 845-868.

Lipsztein, J. L., P. G. Cunha, and C. A. N. Olivera, "The Goiania Accident: Behind the Scenes", Health Physics 60: 5. 


\section{Chapter 2.}

This chapter gives a general overview of the origin, uses, and disposition of radiocesium at Savannah River Site (SRS) under normal operating conditions. The greatest releases of ${ }^{137} \mathrm{Cs}$ occurred during the early years of site operations and originated in the chemical separations facilities and the reactor facilities, which were located near the center of the 800-square-kilometer site. The history of actual releases from specific SRS facilities is presented in Chapter 3. 


\section{Origin of Radiocesium at SRS}

Radiocesium at SRS predominantly originated in the fuel and targets that were irradiated in the nuclear materials production reactors. Other site operations and offsite sources contributed to the inventory of radiocesium at SRS.

\section{Irradiation In Production Reactors}

Most of the radiocesium at SRS was formed as a byproduct in the nuclear fuel and targets during operation of the five production reactors. The role of the production reactors is to produce nuclear materials-principally tritium and plutonium-for national defense purposes. Additional radionuclides, such as ${ }^{28} \mathrm{Pu}$, which is a power source for certain deep-space missions, were occasionally produced for other government purposes.

The reactors became operational between 1953 and 1955 , but have not operated continuously. They have alternated between production operating periods and shutdowns for maintenance or fuel and targets replacement. As of 1988. one reactor was inactive and another was on standby. The three remaining reactors were shut down in 1988 for maintenance and safety upgrades. The history of individual reactor operations is discussed in Chapter 3.

The principal mechanism for radiocesium production in the reactors is neutron-induced fission. When a reactor operates, neutron-induced fission reactions occur in the ${ }^{25} U$ fuel of the reactor core. Fission reactions form a variety of fission products that includes isotopes of cesium. Additional radiocesium is formed in a reactor as the result of neutron activation of stable cesium generated by neutron fission.

In addition to fission products, each neutron-induced fission reaction in the fuel produces several neutrons, some of which induce additional fission reactions and sustain a chain reaction. Some of the remaining neutrons interact with target materials in the reactor. (Fuel and targets are encapsulated separately and referred to as elements.) One such interaction, neutron capture in a $200 \mathrm{U}$ target, results in the production of a speciai nuclear material, ${ }^{20} \mathrm{Pu}$.

In certain target materials, such as ${ }^{20} \mathrm{U}$, neutron-induced fission is a competing reaction. In the case of ${ }^{25} \mathrm{U}$ targets, fission also occurs in the minor constituents such as ${ }^{25} U$ and ${ }^{239} \mathrm{Pu}$.
The abundances of the radioactive fission-product isotopes of cesium that were produced in nuclear fuel and targets at SRS are shown in Table 2-1. The producion of each fission-product isotope was calculated with the SHIELD computer code for "representative" irradiated material. This irradiated material represents the variety of operational parameters that were used from 1953 10 1988. These include composition of fuel and targets, irradiation time, and reactor power level.

The radiocesium activities in Table 2-1 are shown as a function of time after the end of irradiation in order to demonstrate that radiocesium activity levels are significant even after two years of decay. One isotope, ${ }^{134} \mathrm{Cs}$, is included in Table 2-1 even though it is not a fission product. The isotope ${ }^{134} \mathrm{Cs}$ is produced by the $(\mathrm{n}, \mathrm{g})$ nuclear reaction from the stable isotope ${ }^{133} \mathrm{Cs}$ as this fission product accumulates in fuel and target materials.

\section{Other Sources Because of SRS Operations}

Small quantities of radiocesium were produced at SRS by test reactors, spontaneous fission, and neutron activation analysis. The activity levels of radiocesium from these sources are insignificant when compared to the activity levels in irradiated nuclear fuel and targets. However, these sources are discussed in the following subsections to provide a complete overview of potential radiocesium releases.

\section{SRS Test Reactors}

Several small nuclear reactors were in use at two SRS locations from the 1950s through the 1970s. The Heavy Water Components Test Reactor (HWCTR), located in B Area, was used in the early 1960 s to test prototype fuels for a proposed heavy water power reactor. The other test reactors were located in M Area and were used from the mid 1950s to the late 1970s. The Process Development Pile and the Lattice Test Reactor were used as zero-power mock-up facilities to test components for the production reactors. The Subcritical Experimental Pile also was used to test component designs. The Standard Pile provided neutrons for experiments such as neutron radiography and neutron activation. 


\section{Spontaneous Fission}

Spontaneous fission is a radioactive decay mode that occurs in heavy elements such as uranium, and produces neutrons and fission-product radiocesicm. Spontaneous fission is one of the mechanisms for the production of radiocesium in nature. The occurrence of spontaneous fission ranges from rare to frequent. Isotope ${ }^{20} U$ is an example of a radionuclide in which spontaneous fission rarely occurs.

Uranium of various isotopic compositions was chemically purified in preparation for use at SRS. Because of their relatively long half-lives, ${ }^{135} \mathrm{Cs}$ and ${ }^{137} \mathrm{Cs}$ do not reach equilibrium concentration with the ${ }^{20} \mathrm{U}$ in SRS uranium after chemical purification. Approximately 10 half-lives are required to reach $99.9 \%$ equilibrium. For 30 year ${ }^{17} \mathrm{Cs}$, this would require about 300 years ingrowth, and about 23 million years for ${ }^{135} \mathrm{Cs}$. As a result, ${ }^{17} \mathrm{Cs}$ was present in inconsequental quantities, and ${ }^{135} \mathrm{Cs}$ was virtually nonexistent in unirradiated SRS uranium. But, because of the age of the earth, ${ }^{135} \mathrm{Cs}$ and ${ }^{13} \mathrm{Cs}$ do exist in minute quanitities in uranium in nature.
Radiocesium is produced during the spontaneous fission of ${ }^{252} \mathrm{Cf}$. Isotope ${ }^{252} \mathrm{Cf}$ is a valuable neutron source because it frequently undergoes spontaneous fission. Isotope ${ }^{252} \mathrm{Cf}$ was produced in SRS reactors by the irradiation of ${ }^{24} \mathrm{Cm}$ targets. From the mid 1960s until 1987, the Savannah River Laboratory (SRL) fabricated industrial and medical ${ }^{25} \mathrm{Cf}$ sources for offsite use. Some of the sources were retained at SRS for neutron calibrations in the ${ }^{252} \mathrm{Cf}$ fabrication facility and for two neutron activation facilities at SRS. In the 1970 s, one ${ }^{252} \mathrm{Cf}$ neutron activation facility was operated in M Area. The other has been operational at SRL since the mid 1970s.

Other isotopes of uranium and isotopes of thorium, plutonium, and curium also fission spontaneously. One or more of the materials discussed in this subsection was used in $M$ Area, the reactor areas, the chemical separations areas, the Naval Fuels Facility, TNX Semi-Works, or SRL.

Table 2-1. Inventory of Radiocesium Produced in "Representative" Material Irradiated in SRS Production Reactors

\begin{tabular}{|c|c|c|c|c|c|c|}
\hline \multirow[b]{2}{*}{ Isotope* } & \multirow[b]{2}{*}{ Half-Life } & \multicolumn{5}{|c|}{ Curies remaining at various times after end of irradiation } \\
\hline & & $0 \mathrm{sec}$ & $24 \mathrm{hrs}$ & 100 days & 200 days & 2 years \\
\hline${ }^{134} \mathrm{Cs}$ & $2.065 \mathrm{y}$ & $1.104 E+05$ & $1.103 E+05$ & $1.007 E+05$ & $9.185 \mathrm{E}+04$ & $5.642 E+04$ \\
\hline${ }^{134 m} \mathrm{Cs}$ & $2.91 \mathrm{~h}$ & $1.154 E+03$ & $3.722 E+00$ & - & - & - \\
\hline${ }^{135} \mathrm{Cs}$ & $2.30 E+06 y$ & $3.847 E+00$ & $3.847 E+\infty 0$ & $3.847 E+00$ & $3.847 \mathrm{E}+00$ & $3.847 \mathrm{E}+00$ \\
\hline${ }^{135 \mathrm{~m}} \mathrm{Cs}$ & $53 \mathrm{~m}$ & $2.297 E+04$ & - & - & - & - \\
\hline${ }^{136} \mathrm{Cs}$ & $13.1 \mathrm{~d}$ & 4.427E+05 & 4.197E+05 & $2.228 E+03$ & $1.122 \mathrm{E}+01$ & - \\
\hline${ }^{137} \mathrm{Cs}$ & $30.17 y$ & $1.154 E+06$ & $1.154 E+06$ & $1.147 E+06$ & $1.140 E+06$ & $1.102 E+06$ \\
\hline${ }^{138} \mathrm{Cs}$ & $32.2 \mathrm{~m}$ & $1.660 \mathrm{E}+08$ & - & - & - & - \\
\hline${ }^{139} \mathrm{Cs}$ & $9.3 \mathrm{~m}$ & $1.619 E+08$ & - & - & - & - \\
\hline${ }^{140} \mathrm{Cs}$ & $1.06 \mathrm{~m}$ & $1.486 E+08$ & - & - & - & - \\
\hline${ }^{141} \mathrm{Cs}$ & $24.9 \mathrm{~s}$ & $1.125 E+08$ & - & - & - & - \\
\hline${ }^{142} \mathrm{Cs}$ & $1.8 \mathrm{~s}$ & $7.151 E+07$ & - & - & - & - \\
\hline${ }^{143} \mathrm{Cs}$ & $1.78 \mathrm{~s}$ & $3.838 E+07$ & - & - & - & - \\
\hline${ }^{144} \mathrm{Cs}$ & $1.01 \mathrm{~s}$ & $8.274 E+06$ & - & - & - & - \\
\hline${ }^{145} \mathrm{Cs}$ & $0.593 \mathrm{~s}$ & $2.016 E+06$ & - & - & - & - \\
\hline${ }^{146} \mathrm{Cs}$ & $0.322 \mathrm{~s}$ & $2.682 E+05$ & - & - & - & - \\
\hline${ }^{147} \mathrm{Cs}$ & $0.227 \mathrm{~s}$ & $4.466 \mathrm{E}+04$ & - & - & - & - \\
\hline${ }^{148} \mathrm{Cs}$ & $0.15 \mathrm{~s}$ & $2.646 E+03$ & - & - & - & - \\
\hline Totals & & $6.654 E+08$ & $1.684 E+06$ & $1.250 \mathrm{E}+06$ & $1.232 E+06$ & $1.158 \mathrm{E}+06$ \\
\hline
\end{tabular}

* The " $\mathrm{m}$ " designates a metastable energy state greater than the ground state of a particular isotope. 
Neutron Activation Analysis

Neutron activation analysis is an analytical technique for measurement of elemental compositions in materials. The ${ }^{252} \mathrm{Cf}$ neutron activation facilities and the $\mathrm{C}$ and $\mathrm{K}$ production reactors were used for the analysis of low levels of ${ }^{129} \mathrm{I}$ and uranium. For example, from the late 1970s to mid 1980s, environmental samples were activated in C Reactor to determine uranium content. Traces of fission-product radiocesium were produced in the irradiated samples.

\section{Materials Originating Offsite}

Certain fuels that were irradiated at offsite non-commercial facilities were shipped to SRS for reprocessing. While awaiting reproc's sing, the fuel was stored in the Receiving Basin for Offsite Fuel (RBOF) located in H Area.

Additional ${ }^{17} \mathrm{Cs}$ was purchased from commercial vendors. The isotopes were used at SRS for experimental purposes, such as chemical yield determination, and for instrument calibration. SREL also used a multicurie array of encapsulated ${ }^{17} \mathrm{Cs}$ in a series of radiation effects studies. While curie quantities of radiocesium are present at SRS due to commercial purchases, the amount is insignificant when compared to that produced in fuel and targets in SRS production reactors or produced in fuel offsite but stored in RBOF.

SRS and surrounding areas have been subjected to global fallout of manmade radiocesium since the 1940s. During the era of extensive atmospheric nuclear weapons testing in the 1950 s and early 1960s, fallout was often found to be the predominant source of radiocesium in the vicinity of SRS. Additional radiocesium was deposited in the SRS environment as the result of the Chernobyl reactor accident in Russia in 1986. Environmental radiocesium is discussed in Chapter 4. 


\section{Disposition of Radiocesium at SRS}

The principal means for disposing of radiocesium are containment and time, which allows radioactive deciay to occur. Table 2-1 shows that very short-lived isotopes of cesium produced in SRS reactors decayed to insignificant activity levels shortly after the end of irradiation. To describe the disposition of the longer-lived isotopes, the sources of radiocesium are categorized as follows:

\section{Major sources}

- fuel and targets irradiated in production reactors

- certain fuels irradiated offsite

\section{Minor sources}

- fuel and targets irradiated in SRS test reactors

- spontaneous fission

- neutron activation samples

- commercially purchased radiocesium

- global fallout

\section{Radiocesium in Fuel and Targets Irradiated in Production Reactors}

Under ideal operating conditions, radiocesium is contained within the cladding of fuel and target elements during both irradiation and cooling. $C$ oling is the interval between the end of irradiation and the beginning of chemical separations. Irradiated materials are stored underwater in reactor basins for most of this time. Beginning in the 1970s, the cooling time was at least $\mathbf{2 0 0}$ days for most irradiated materials for control of radioiodine emissions. This cooling time had relatively litule effect on the inventory of the cesium isotopes 134, 135, and 137, however.

Under normal operating conditions, it was possible for radiocesium to escape from irradiated fuel and target elements to the reactor moderator or to the water in the cooling basins through small defects in the cladding. Accordingly, air and water at reactors were monitored for such possible releases of radiocesium. Actual releases are described in greater detail in Chapter 3.

Occasionally, the small defects developed into holes or splits in the cladding, causing a failure of the element. When a failure occurred, the reactor "Nas shut down and the failed element was transferred into a container called a "harp". The harp was stored underwater in the reactor basin and vented to the reactor stack. Failures occurred more frequently in the early years of operation than in later years.

A failed element had the potential to contaminate the moderator with radiocesium - SRS reactors used heavy water as a moderator. When the moderator and miscellaneous waters were purified using the treatment systems at reactors or the Heavy Water Rework Facility in D Area, there was a potential for very small quantities of ${ }^{134} \mathrm{Cs},{ }^{133} \mathrm{Cs}$, and ${ }^{137} \mathrm{Cs}$ to be released. These small quantities were generally not measurable by routine methods.

Water in the reactor cooling basins also had the potential to become contaminated with radiczesium. Beginning in the 1960 s, basin water was routinely decontaminated by passing the water through ion exchange resins to remove most of the radionuclides. Spent resins were reworked in the Resin Regeneration Facility in $\mathrm{H}$ Area or buried in the Burial Grounds (in 1990 the Burial Grounds were renamed as Solid Waste Disposal Facility).

During the cooling period, short-lived radionuclides decayed $\omega$ insignificant levels. Table 2-1 shows this for isotopes of cesium. After 200 days of cooling, the cesium isotopes 134, 135, 136, and 137 constituted the only radiocesium remaining in measurable quantities.

After the cooling period, fuel and targets were treated in the chemical separations areas. During the chemical separations process, targets were treated by the Purex process in $F$ Area to recover ${ }^{239} \mathrm{Pu},{ }^{27} \mathrm{~Np}$, and ${ }^{200} \mathrm{U}$ from irradiated ${ }^{28} \mathrm{U}$. The Purex process extracted plutonium and uranium into an organic solvent for separation and purification from waste products.

Fuel was treated by the HM process in H Area to recover ${ }^{20} \mathrm{U}$ and ${ }^{27} \mathrm{~Np}$ from irradiated ${ }^{25} \mathrm{U}$. Until 1959 the Purex process was used in $\mathrm{H}$ Area. The principal difference between the HM process and the Purex Process is that the HM process uses mercuric nitrate as a catalyst to enhance the dissolution of the irradiated fuel. Isotope ${ }^{20} \mathrm{Pu}$ was occasionally recovered from ${ }^{27} \mathrm{~Np}$ targets by the Frames process in H Area.

During chemical separations, small quantities of cesium were volatilized during the evaporation of aqueous wastes and were subsequently discharged to seepage basins. Small quantities of cesium have gotten into the process cooling 
water streams in both $\mathrm{F}$ and $\mathrm{H}$ Areas as the result of heating and cooling coil leaks. While the bulk of this activity was collected in retention basins and subsequently transferred to the seepage basins, some leakage into Four Mile Creek did occur. Additional small quantities of radiosesium seeped through small cracks that developed in some of the high activity waste tanks and subsequently spilled into the soil underneath the tanks.

Aqueous wastes from the chemical separations processes were evaporated and then sent to underground storage tanks for radioactive waste. The condensate from evaporation was sent to the separations area seepage basins until November 1988 when use of the seepage basins was terminated. Miscellaneous aqueous wastes were periodically treated by the evaporation process.

Beginning in November 1988, condensate was sent to the Effluent Treatment Facility where it was treated to remove radionuclides (except tritium) and chemicals before being discharged to Upper Three Runs Creek.

High-level liquid wastes generated in the SRL operations were stored in temporary waste tanks where short-lived radionuclides decayed to insignificant levels. Periodically, the contents of the waste tanks were shipped to F Area and processed through the waste system. Solid wastes generated in the SRL handling operations were allowed to decay to low levels and then buried in the Solid Waste Disposal Facility.

Most of the atmospheric and aqueous effluents in the chemical separations areas and SRL have been monitored for possible radiocesium releases. Monitoring techniques and measured releases from the chemical separations areas are described in Chapter 3.

The distributions to the atmosphere, seepage basins, and plant streams had a direct impact on the environment. Radiocesium released through stacks was small enough so that offsite cesium transported through the atmosphere has not been detected. Waterborne cesium was measurable in the Savannah River water and silt in the tidal estuary at Savannah, Georgia, in the early and mid 1960s. Radiocesium bound in river sedinients was deposited both onsite and in the offsite swamp below the mouth of Steel Creek. Additional amounts of radiocesium contaminated sediments are known to exist along the Lower Three Runs Creek stream bed.

Groundwater transport of cesium from the seepage basins and the Solid Waste Treatment Facility is relatively small because of the high affinity of local clays for the cesium ion. Water from the Separations Area seepage basins migrated downward to shallo'w groundwater aquifers that outcrop near Four Mile Creek, which flows into the Savannah River. While no documented evidence of significant migration of radiocesium in groundwater is known, transport of significant quantities of radiocesium in Four Mile Creek has been reported. Up to 32 curies migrated downstream in Four Mile Creek in 1967. Lesser amounts have been recorded in subsequent years as detailed in Chapter 3 . The radiocesium transport in Four Mile Creek was autibuted to streambed desorption. The source of the criginal cesium was a liquid waste spill in the H-Area tank farm.

\section{Radiocesium in Certain Fuels Irradiated Offsite}

Irradiated fuels received from certain offsite facilities were stored underwater in RBOF until the fuel was ready for chemical separation. The fuel then entered the regular process stream in $\mathrm{H}$ Area. The disposition of radiocesium became the same as described for fuel irradiated in SRS production reactors.

\section{Radiocesium in Fuel and Targets Irradiated in Test Reactors}

Fuels and targets from the various test reactors were sent primarily to the RBOF for cooling before chemical separations. Some were sent to SRL for research or to reactor materials fabrication facilities, which only received fuel or targets that were not irradiated. This material was blended into the standard fabrication process for targets and fuel to be used in the production reactors. Because only minute quantities of naturally produced radiocesium occurred in the fabricated materials, such as ${ }^{238} \mathrm{U}$, no monitoring for radiocesium was conducted at fabrication facilities.

\section{Radiocesium From Spontaneous Fission}

Radiocesium produced by spontaneous fission in thorium, uranium, plutonium, and curium is retained by these elements as long as they remain in solid form. Radiocesium produced by spontaneous fission in ${ }^{252} \mathrm{Cf}$ is retained as long as the califomium remains encapsulated.

\section{Neutron Activation Analysis Samples}

Environmental samples were analyzed by high sensitivity neutron activation for the detection of trace levels of uranium and ${ }^{129} \mathrm{I}$. Typically, the uranium analysis was 
non-destructive; therefore, any radiocesium produced from fission of uranium was not released. The radiocesium content was minute and the samples were disposed in the Solid Waste Disposal Facility as solid radioactive waste.

The analysis for ${ }^{12}$ I typically involved chemical purification of iodine at SRL after irradiation. In the purification steps, traces of the activation products ${ }^{14} \mathrm{Cs}$ and ${ }^{137} \mathrm{Cs}$ could have been released to the SRL exhaust system. None of these trace releases were significant enough to be detected in routine radiocesium monitoring of the SRL stacks.

Traces of radiocesium were retained in various liquids that were used in the purification steps and then stored in the SRL temporary waste tanks. These wastes were subsequently concentrated by evaporation and added to the high level wastes awaiting processing in the DWPF.

\section{Commercially Purchased Radiocesium}

The isotopes ${ }^{134} \mathrm{Cs}$ and ${ }^{137} \mathrm{Cs}$ were purchased from commercial venders primarily for use as instrument calibration sources. Small quantities were purchaser sor standardization of counting room instruments in several SRS laboratory facilities. After measurements, the radiocesium, in solid form, was disposed of as solid radioactive waste. In cases where chemical separation and purification of cesium occurred, the disposition of radiocesium was similar to that described for neutron activation analysis samples. Encapsulated, multicurie sources of ${ }^{17} \mathrm{C}$. have also been purchased for use as calibration sources for Healu Protection survey instruments. These latter sources will be disposed of as solid radioactive waste when their useful life cycle is complete.

\section{Global Fallout Radiocesium}

Most global fallout occurred because of atmospheric nuclear weapons tests and the Cl.ernobyl accident. Global fallout of ${ }^{137} \mathrm{Cs}$ was often detectable in the vicinity of SRS during the 1950 s, early 1960 s, and in 1986. Fallout was not uniformly distributed throughout the terrestrial environment in the vicinity of SRS. Such unpredictability in the terrestrial distribution was well known in the early 1960 s (Bruner, 1963). 


\section{References}

Bruner, H. D., 1963, "Symposium on the Biology of Radioiodine: Statement of the Problem", Health Physics, 9:1083.

EPA (U.S. Environmental Protection Agency), 1977, "National Interim Primary Drinking Water Regulations",
EPA-570/9-76-003, U.S. Environmental Protection Agency, Washing!.un, DC. 


\section{Chapter 3. Releases and Stored Inventories of Radiocesium at $S R S$}

Routine operations at SRS facilities have released radiocesium to the regional environment surrounding Savannah River Site (SRS). The most significant releases occurred during the early years of site operations when radiocesium was released to seepage basins and site streams. The greatest releases of radiocesium originated in the waste management facilities, located near the center of this 800-square-kilometer site. The proximity of these facilities to major streams within the boundary of SRS is shown in Figure 3-1, which also shows the location of other facilities having the potential to release radiocesium.

This chapter presents a discussion on radiocesium at $S R S$ facilities in terms of possible release pathways, emission control features, and annual releases to the aqueous and atmospheric environments.

The releases that have occurred were usually the result of abnormal operating events, such as fuel failures, cooling coil leaks, or faulty storage containers. One such event in 1957 caused the failure of a fuel tube in the $R$-Area isolation basin. As a result of the failure, the $R$-Area releases for 1957 were approximately 47 curies of ${ }^{17} \mathrm{Cs}$ to Lower Three Runs Creek (out of a site total of 49 curies for the year) and another 788 curies (out of a site total of 790 curies) to the R-Area seepage basins. The combined effects of leaking "harps" (failed fuel element storage containers) and disassembly basin purges directly to streams resulted in chronic releases to streams during the period from 1959 through 1970. The maximum releases occurred in 1964 when a total of 109 curies of ${ }^{17} \mathrm{Cs}$ was released $t 0$ plant streams from the reactor areas (area-by-area contributions were $\mathrm{R}-47.1 \mathrm{Ci} ; \mathrm{P}-45.6 \mathrm{Ci} ; \mathrm{L}-7.7 \mathrm{Ci} ; \mathrm{K}-5.6 \mathrm{Ci}$; and $\mathrm{C}-2.4 \mathrm{Ci}$ ).

Initially, clarity of water in the vertical tube storage (VTS) basins in the reactor areas was maintained by continuously purging the basins with fresh, filtered river water. In an effort to minimize the release of radioactivity to plant streams, recirculating filters were first added. Then, in the early 1970s, sand filters were installed in all the operating reactor areas and the VTS water was totally recirculated. However, because of the buildup of tritium in the VTS basin water, periodic purges of the basins were still necessary. These purges were passed through ion exchange beds to remove most of the radivactivity before discharge to the environment. Purges occurred to both seepage basins and to plant streams. Total site radiocesium releases to streams have not exceeded $1 \mathrm{Ci}$ in any year since 1974. 


\section{Reactor Facilities}

The five production reactors at SRS are identified by the letter designations $C, K, L, P$, and $R$. The reactors were designed to irradiate various targets to produce nuclear materials (principally tritium and plutonium) for national defense purposes. Specific radionuclides for cther government purposes were also produced, such as ${ }^{200} \mathrm{Pu}$, which is a power source for certain deep-space missions.

\section{Facility Operations}

Since becoming operational between 1953-1955, the reactors have not operated continuously. They have periodically been shut down for maintenance, safety upgrades, or replacement of fuel and targets. In 1988, three of the five reactors were shut down for extensive maintenance and safety upgrades. Prior to 1988, one reactor was placed on inactive status and another on standby.

When a nuclear production reactor is operating, nuclear fission reactions occur in the reactor core. The principal components of the core are the fuel, targets, control rods, and moderator. Control rods are neutron-absorbing materials that are positioned in the core to control the power level of a reactor.

The moderator in SRS reactors is heavy water, which is circulated around the fuel and target elements in the reactor core. The moderator decreases the kinetic energy of (slows the speed of) neutrons emitted in the fission process. Slow neutrons have a grcater probability for interaction with fuel and target materials than fast neutrons.

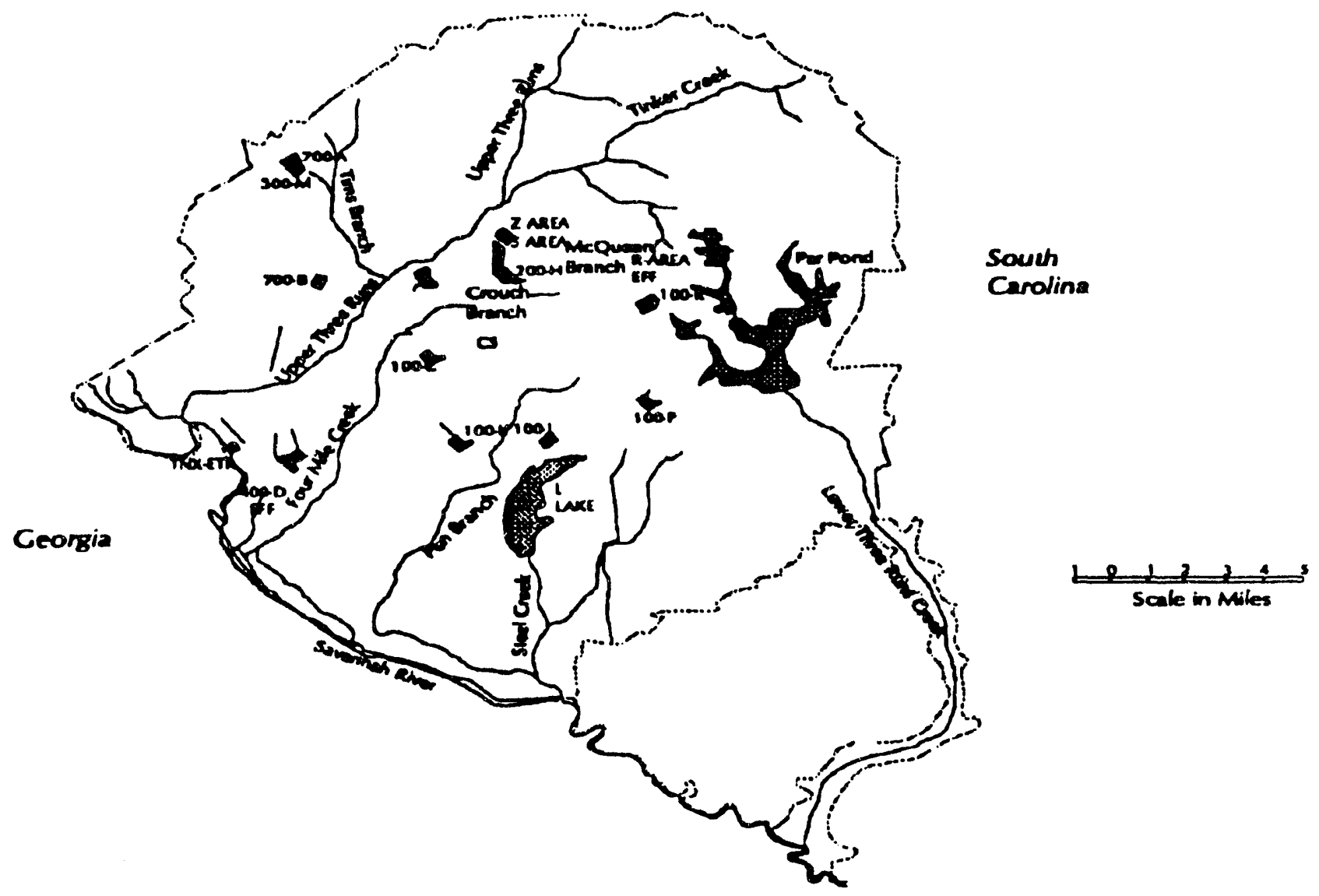

Figure 3-1. Proximity of SRS Facilities to Site Streams 
The moderator also functions as the primary coolant to remove heat from fuel and target elements. Heat is then transferred from the moderator by heat exchangers to the secondary coolant. SRS reactors use either river or pond water as the secondary coolant in the heat exchangers.

In reactors that use Savannah River water as the secondary coolant, the river water is passed through the shell side of the heat exchanger and discharged to a site stream that flows to the Savannah River. Reactors that use pond water as the secondary coolant discharge the water from the heat exchanger to a canal that flows to a series of cooling ponds. Cooled pond water is recirculated through the heat exchanger.

Under normal operating conditions, fuel and target elements are irradiated for a specified time, removed from the reactor core, and stored underwater in the vertical tube storage (VTS) basin of the reactor building. Storage in VTS for tie cooling period, which, as of 1988, was at least 200 days, allowed short-lived radionuclides to decay to low levels before the reprocessing of the fuel and targets began. After cooling, the elements are moved to the disassembly basin and prepared for transfer to the chemical separations areas.

The abnormal condition of a fuel or target failure is detected by sensors in the reac tor core. When a failure occurs, the reactor is shut down and the failed element is transferred into a "harp". The harp is stored underwater in the reactor basin and is vented to the reactor stack.

\section{Pathways for Release}

During normal reactor operations, traces of radiocesium escaped from irradiated fuel or target elements if a defect developed in the cladding. The defect typically was a micro-scale crack. If a defect developed while the element was in the reactor core, radiocesium escaped from the irradiated material to the moderator by leaching radiocesium from the exposed irradiated material.

Some of the exposed uranium and plutonium on failed elements became dispersed in the moderator. After the failed elements were removed and the reactor restarted, the dispersed uranium and plutonium continued to circulate with the moderator. Neutrons generaled during subsequent reactor operation cause fission in any circulating uranium and plutonium, thereby producing small quantities of radiocesium directly in the moderator. Most of these impurities are removed from the moderator by an online ion exchange purification process, which removes most of the uranium, plutonium, and fission products.
Once in the moderator, radiocesium could circulate with the moderator and adsorb onto fuel and target surfaces. Low operating temperatures of the reactors (below the boiling temperature of heavy water) and the very high solubility of cesium compounds in water minimizes the volatilization of cesium into the blanket gas.

Similar pathways occurred in the VTS basin during cooling of irradiated materials and in the disassembly basin. Radiocesium escaped to basin water from cladding microdefects or by water leaching radiocesium from the exposed irradiated material in failed elements. Water also leached adsorbed radiocesium from the exterior surfaces of fuel and targets. Once radiocesium was in the basin water, it circulated with the water, became trapped in the deionizer, adsarbed onto fuel and target surfaces. Again, low temperatures and radiocesium solubility minimized the airborne release of radiocesium from the VTS.

Circulating moderator and basin water were the primary pathways by which aqueous radiocesium was released to the environment. Moderator could have mixed with the sucondary coolant if a leak existed in the reactor heat exchanger. Any radiocesium released by this pathway was not quantified. However, the secondary coolant was monitored for beta-gamma activity. Leakage to the secondary coolant was a minor pathway compared to the basin water pathway.

As indicated in earlier discussions, reactor basin waters were initially purged directly to site streams to remove the heat generated by the stored irrar'iated fuel and targets and to maintain clarity in the storage basins. After installation of basin heat exchangers, deionizers, and filters in the 1960 s, the volume of purge water decriased significantly as did the releases of radioactivity.

Periodic purges were performed to eliminate tritium, the accumulation of which resulted in exposure to operating personnel. Purges were discharged to earthen seepage basins as well as streams. When discharged to streams, the purge water became diluted with much larger volumes of secondary cooling water. Reactor basin discharges to site streams ceased in 1978.

After 1978, reactor basin discharges were directed to the reactor seepage basins. Because local clay soils have a very high affinity for cesium, most radiocesium discharged to the seepage basins remains fixed in the first few inches of soil in the basin walls and floor.

A source of wastewater that had low potential for containing radiocesium was the reactor process sewer system. This system principally received cocling water from the shell 
side of heat exchangers for reactor basins and other miscellaneous process waters. Process sewer water was periodically sampled and analyzed for radionuclides.

Other wastewater was collected in process sumps at the reactor facilities. Occasionally, this wastewater contained moderator from leaks that developed during reactor operations or spills that occurred when line breaks were made during maintenance periods. The wastewater was collected and analyzed for both radionuclides and moderator content. Depending on analy'sis results, possible disposition methods, were (1) processing through the Heavy Water Rework Facility or the waste evaporators in the separations areas, or (2) discharge to seepage basins or streams.

Vulatilization from moderator leaks or spil's had the potential to introduce radiocesium into the piucess ventilation system. Air in the process ventilation system first passed through a HEPA filter designed to remove particulates such as radiocesium and was then exhausted to the atmospheric environinent from a 60-meter stack. However, during periods when the reactor was shut down for repairs, maintenance, or replacement of fuel and targets, air from the reactor building levels that were 6 and 12 meters below grade elevation was allowed to bypass the filter beds enroute to the stack. This bypass occurred because a large air flow was required to remove tritium from process areas where work was performed. The capacity of the HEPA filters was insufficient to handle an air flow that was 2103 times greater than normal for an extended period of time.

Direct atmospheric releases of radiocesium from the VTS basin water is minimal. Occasional traces of cesium are found in air samples as a result of decay of volatile noble gases that escape from failed fuel tubes. The levels are so low that extremely sensitive instruments are required for detection. Radiocesium is not detectable in routine air sampling.

Because cesium is readily bound in seepage basin soils, the only source of airbome cesium near the basins is resuspension of cesium-containing dusts that could form in dry basins which had earlier received liquid discharges. The stmospheric concentrations of radiocesium at these basins are expected to be less than minimum detectable concentrations because, typically, no radiocesium was detected in VTS air and the water was passed through a deionizer before being purged.

\section{Emission Control}

Various measures were implemented to minimize releases of radioactivity. One of these was the extensive improve- ment in the quality of materials fabricated for irradiation. Such improvements minimized the formation of defects in the cladding of fuel and targets.

In the reactor areas, procedural changes were implemented to reduce releases. In 1963, provisions were made for recirculating basin water through heat exchangers to be cooled and deionized to remove radionuclides (except tritium), which reduced discharge volumes considerably. Prior to 1963, basin water was continuously purged to site streams. Although the deionizers were effective in removing particulates, nermanent sandfilters were installed in the late 1960 s to maintain water clarity. The residues collected on the sandfilters were transported to F Area to be processed and stored in waste tanks. Spent deionizer resin was transported to $\mathrm{H}$ Area for regeneration.

Most of the radiocesium released in the early years of reactor operation originated in failed fuel elements. Failures or suspected failures of elements were detected by reactor core sensors. In 1957 the practice of placing failed elements in "harp" storage containers was implemented.

Under normal operating conditions, moderator and some residual radionuclides adhered to fuel and target surfaces when removed from the reactor core. To reduce the adhering radioactivity, a practice of flushing these elements during the discharge process was implemented in the late 1960s. The flushing removed most of the adhering moderator and some residual radionuclides (such as radiocesium). After flushing, the elements were stored in the VTS and the flush water was collected in drums for treatment in the D-Area Heavy Water Rework Facility.

Atmospheric releases were minimized by the use of a confinement system, which was intended not only for routine operations, but also for reactor incidents. The system consists of a demister filter bank, a particulate HEPA filter bank, and a carbon filter bank to remove radioiodine.

\section{Release Monitoring}

Reactor stack air is, and has been, continuously sampled for particulate radioactivity. Because of the very low level of airbome radiocesium in the reactor exhaust air, specific analyses for these radionuclides is not performed.

Several techniques were used to monitor aqueous releases. Cooling water was monitored for beta-gamma activity, and specific radiochemical analyses for radiocesium were performed. Basin purge water has been routinely analyzed in the laboratory for ${ }^{137} \mathrm{Cs}$ since the middle 1950s. Gamma spectrometry techniques were introduced in the 1960 s. 
Low-level cesium analyses in streams were enhanced by the use of cesium specific ion exchange materials. Specific analysis for ${ }^{135} \mathrm{Cs}$ is not performed because of the lack of gamma emission and the difficulty of detection in the presence of ${ }^{134} \mathrm{Cs}$ and ${ }^{137} \mathrm{Cs}$. Both ${ }^{134} \mathrm{Cs}$ and ${ }^{17} \mathrm{Cs}$ have specific activities nearly a million times greater than ${ }^{135} \mathrm{Cs}$ and are thus more significant in both human and environmental doses by several orders of magnitude.

\section{History of Measured Releases}

Aqueous releases from each reactor have decreased significantly over the years of operation. Typically, less than $1 \%$ of the wotal aqueous releases of ${ }^{137} \mathrm{Cs}$ from a given reactor occurred after the restrictive release guides were implemented beginning in 1972.

In terms of annual aqueous releases, the annual releases of ${ }^{17} \mathrm{Cs}$ in the 1980 s were approximately $0.1 \%$ of the annual releases in the early 1960 s. Atmospheric releases, which were small to begin with, did not decrease in the multiple order-of-magnitude that characterized the aqueous releases.

The greatest measured aqueous releases of ${ }^{17} \mathrm{Cs}$ from reactors occurred during the period 1957 through 1970. These releases were typically associated with failures of irradiated fuel elements in the reactor core.

\section{Reactor}

C Reactor was operational from 1955 until it was shut down for extensive maintenance in 1985 . It was placed in standby mode in 1987. Reactor basin purges were discharged into Four Mile Creek and three seepage basins designated 904-66G, -67G, and -68G. The seepage basins were used from 1959 to 1970 and, again, from 1978 through 1984.

The total measured aqueous release of radiocesium from C Reactor during its operational lifetime was 32.92 curies to Four Mile Creek and 2.05 curies to the seepage basins. The greatest annual release, approximately 9.73 curies to Four Mile Creek, occurred in 1970 just prior to installation of the recirculating filtration system as shown in Figure 3-2. Annual releases in excess if 1 curie/year occurred several times during the period 1959 through 1970. The final discharges of aqueous ${ }^{17} \mathrm{Cs}$ to Four Mile Creek occurred in 1981. Discharges of treated liquid purges of the VTS basins have been directed to the seepage basins (see Figure 3-3) from 1982 to present times.

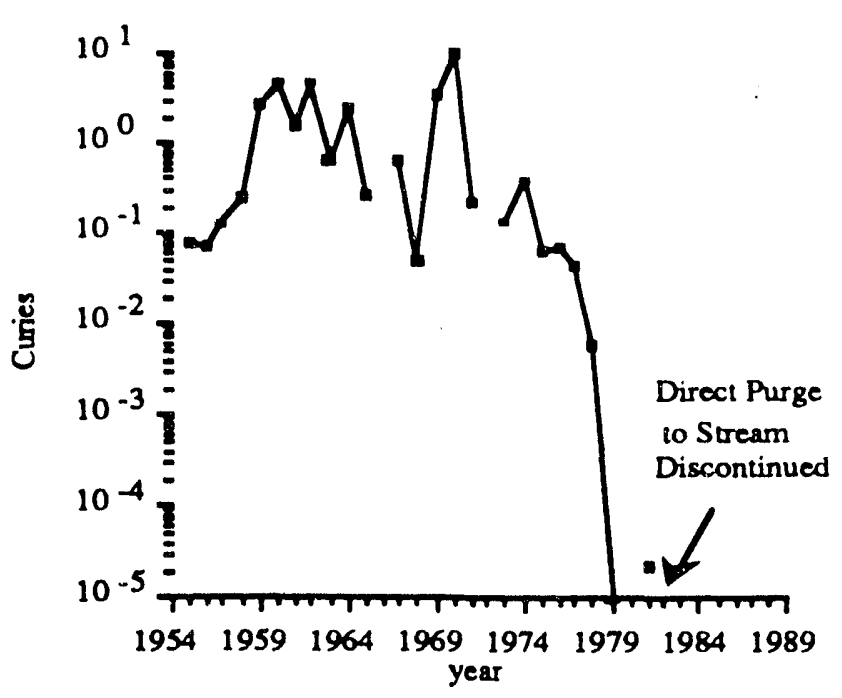

Figure 3-2. Cesium Releases to Streams, C Area

\section{K Reactor}

K Reactor was operational from 1954 until the 1988 shutdoun of all reactors. Reactor :ooling basin purges were disctarged to Pen Branch and to two earthen basins outside the building - a seepage basin designated $904-65 \mathrm{G}$ and a containment basin designated 904-88G. Because of poor seepage characteristics, 904-65G received disassembly

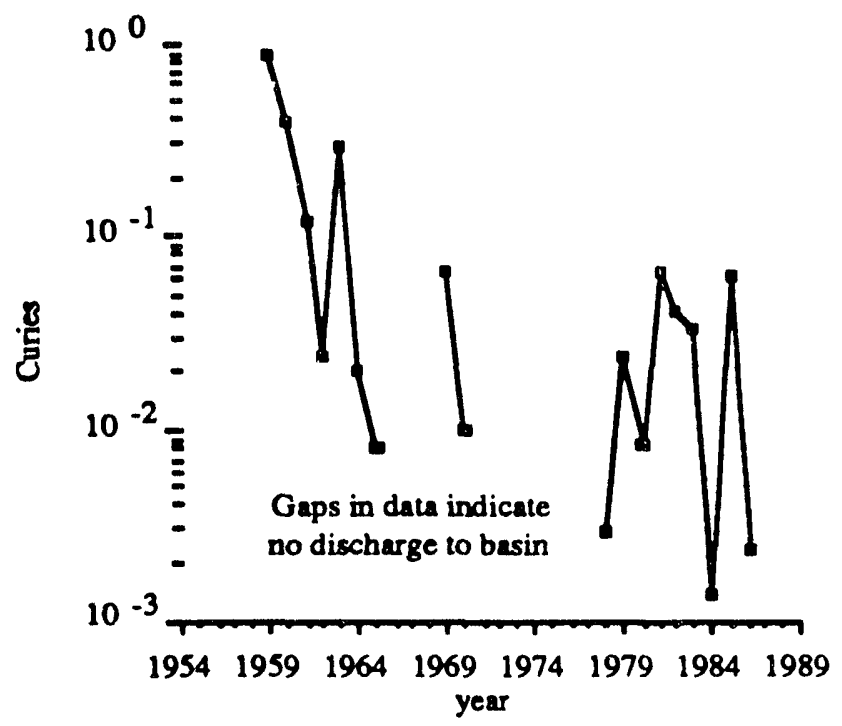

Figure 3-3. Cesium Releases to Seepage Basins, C Area 


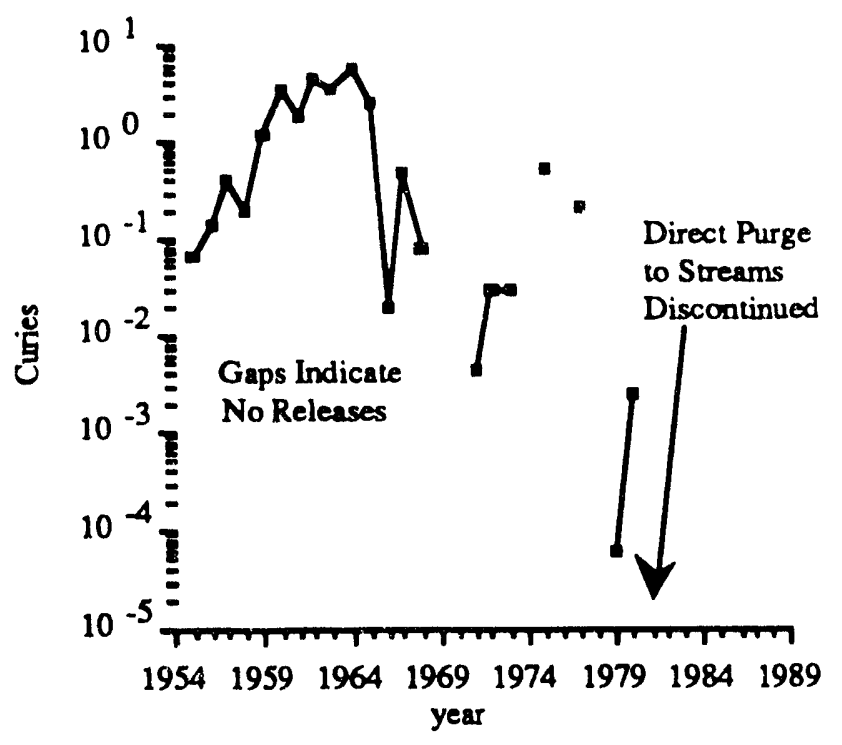

Figure 3-4. Cesium Releases to Streams, K Area

basin purges only in 1959 and 1965. Containment basin 904-88G was used to receive disassembly basin purges and occasional miscellaneous wastewater discharges from 1965 through 1989.

The total measured aqueous releases of ${ }^{134} \mathrm{Cs}$ and ${ }^{137} \mathrm{Cs}$ from K Reactor through 1989 was 24.63 curies to Pen Branch and 13.57 curies to the seepage and containment basins. Measured annual aqueous releases of radiocesium to streams are shown in Figure 3-4. The maximum annual release, 8.12 curies to the containment basin, occurred in 1970 (see Figure 3-5). Releases in excess of 1 curie/year to

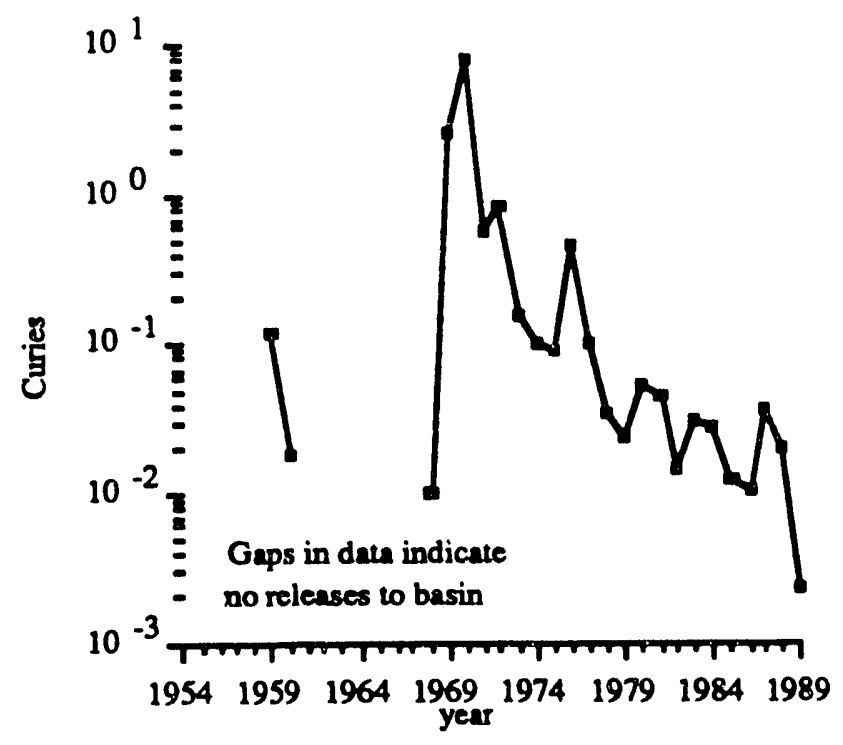

Figure 3-5. Cesium Releases to Seepage Basins, $\mathrm{K}$ Area

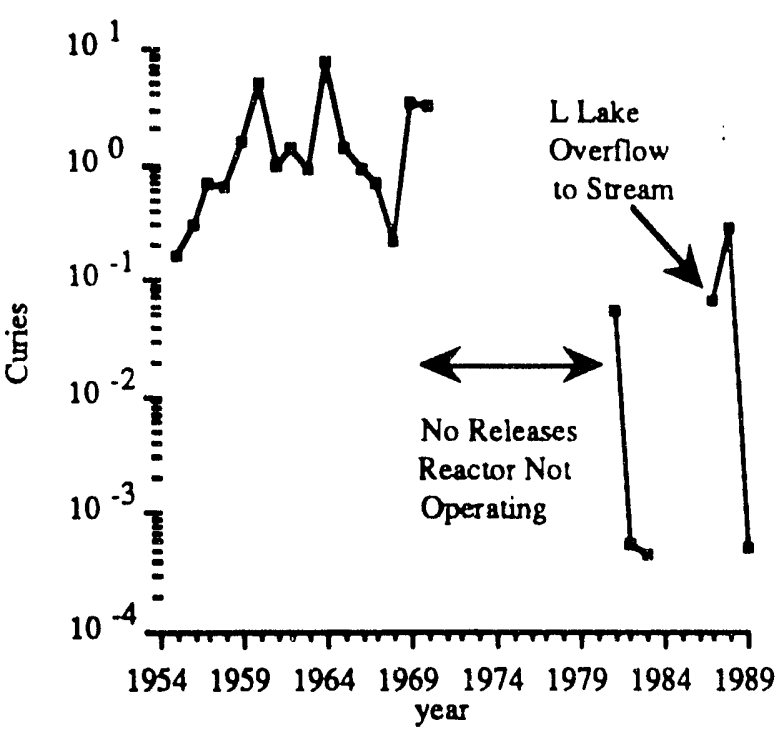

Figure 3-6. Cesium Releases to Streams, L Area

Pen Branch occurred from the period 1960 through 1966, with a maximum of 5.62 curies occurring in 1965.

\section{Reactor}

L Reactor was operational from 1954 to 1968 when it was placed in standby. It was refurbished beginning in the early 1980s, restarted in 1985, and operated until the 1988 shutdown. To provide thermal mitigation of secondary cooling water from the restarted reactor's heat exchanger, $\mathrm{L}$ Lake was constructed in the early 1980 s by damming Steel Creek. Therefore, during $L$ Reactor's second operational period, secondary cooling water from the reactor heat exchanger was discharged to L Lake, which drains into Steel Creek.

Reactor basin purges were discharged to Steel Creek, L Lake, and a seepage basin designated 904-64G. The 904-64G seepage basin was used intermittently in 1958, 1959, 1961 to 1965, 1967 to 1969, and 1985 through 1989. The L Area Oil and Chemical Basin (904-83G) was used from 1961 to 1979 to receive wastewater ccntaining various oils and chemicals from all of the reactor areas. It is adjacent to the 904-64G seepage basin.

The total measured aqueous reles cer ${ }^{137} \mathrm{Cs}$ from L Reactor through 1989 was 29.68 curies $w$ sueel Creek (see Figure 3-6) and 2.75 curies to the seepage basins (see Figure 3-7). Measured annual aqueous releases of ${ }^{17} \mathrm{Cs}$ to stream and lake are shown in Figure 3-6. The greatest annual release, 7.74 curies to Steel Creek, occurred in 1964. Releases in 


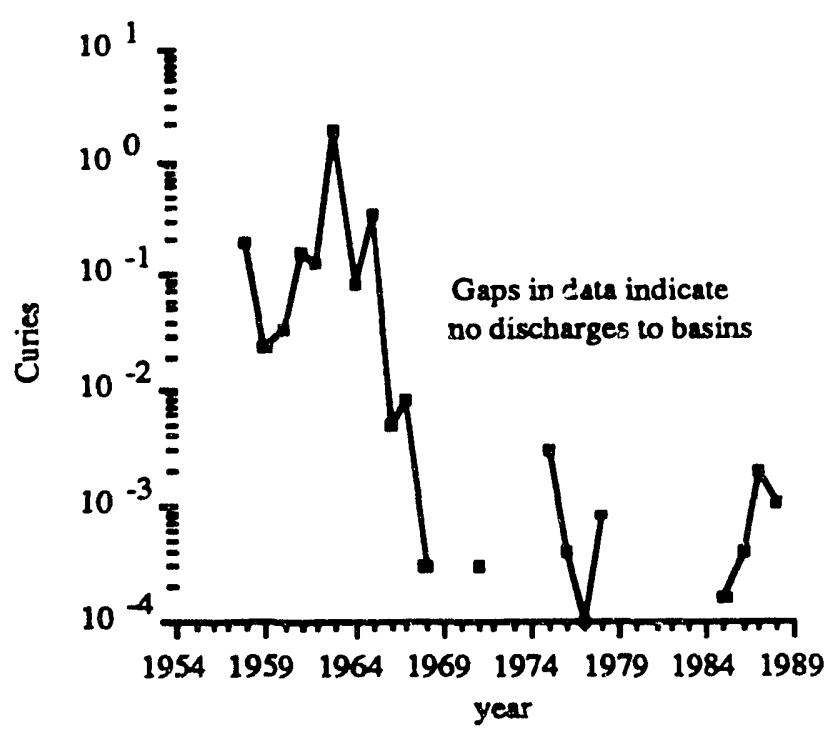

Figure 3-7. Cesium Releases to Seepage Basins, L Area

excess of 1 curie/year occurred seven times during the period 1959 through 1970. During the L Reactor second operational period, aqueous radiocesium was not discharged directly to Steel Creek.

\section{P Reactor}

P Reactor was operational from 1954 until the 1988 shutdown. Reactor basin purges were discharged to Steel Creek and Par Pond from 1954 to 1956, 1969, and from 1971 to 1977 , and to three seepage basins during 1957 to 1968 , 1970 , and 1978 through 1989. The seepage basins have designations 904-61G, -62G, and -63G.

Reactor cooling water and miscellaneous effluents were discharged to Steel Creek until 1963. Most of the cooling water was later diverted to Par Pond. When L Lake was constructed in the mid 1980s, all aqueous effluents were diverted to Par Pond.

The total measured stream releases of radiocesium from $P$ Reactor through 1989 was 254.7 curies to the Steel Creek/Par Pond system (see Figure 3-8) and 19.58 curies to the seepage basins (see Figure 3-9). Measured annual 8queous releases of ${ }^{134} \mathrm{Cs}$ and ${ }^{137} \mathrm{Cs}$ are shown in Figure 3-8. The greatest annual releases, 45.6 curies to Steel Creek, occurred in 1964. Releases of 45.1 and 41.1 curies occurred in 1967 and 1968 respectively. Releases of ${ }^{137} \mathrm{Cs}$ in excess of 1 curie/year occurred every year from 1960 through 1971 , primarily because of failed fuel wbes stored in leaky "harps".

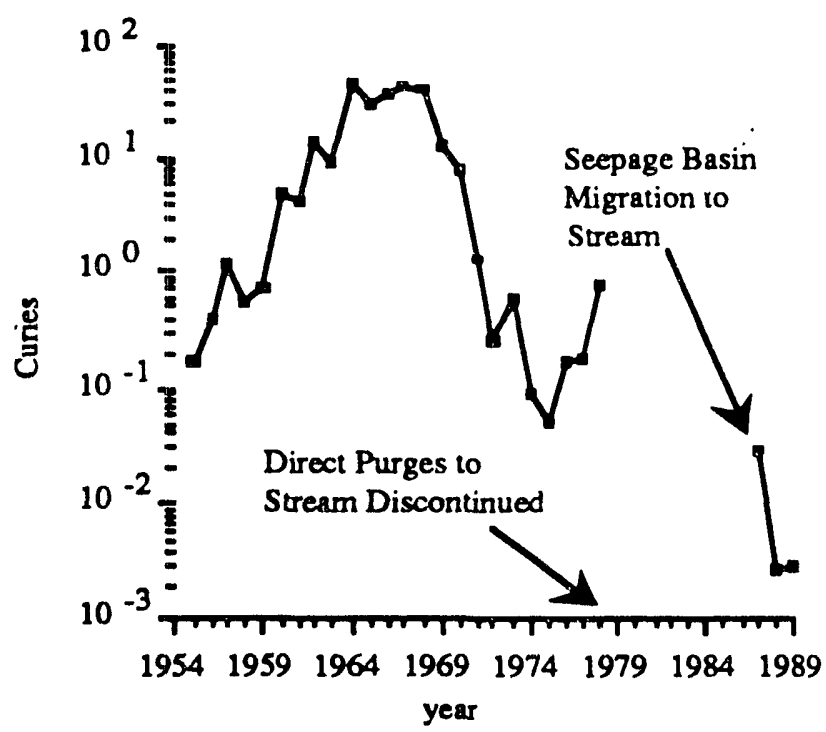

Figure 3-8. Cesium Releases to Streams, P Area

\section{R Reactor}

R Reactor was the first operational production reactor at SRS. It operated from late 1953 until 1964 when it was placed on inactive status. Reactor basin water was discharged into Lower Three Runs Creek from 1954 to 1958, into Par Pond from 1958 to 1964, and into a seepage basin system from 1957 to 1964. R Reactor had six seepage basins designated 904-103G, -104G, -57G, -58G, -59G, and -60G.

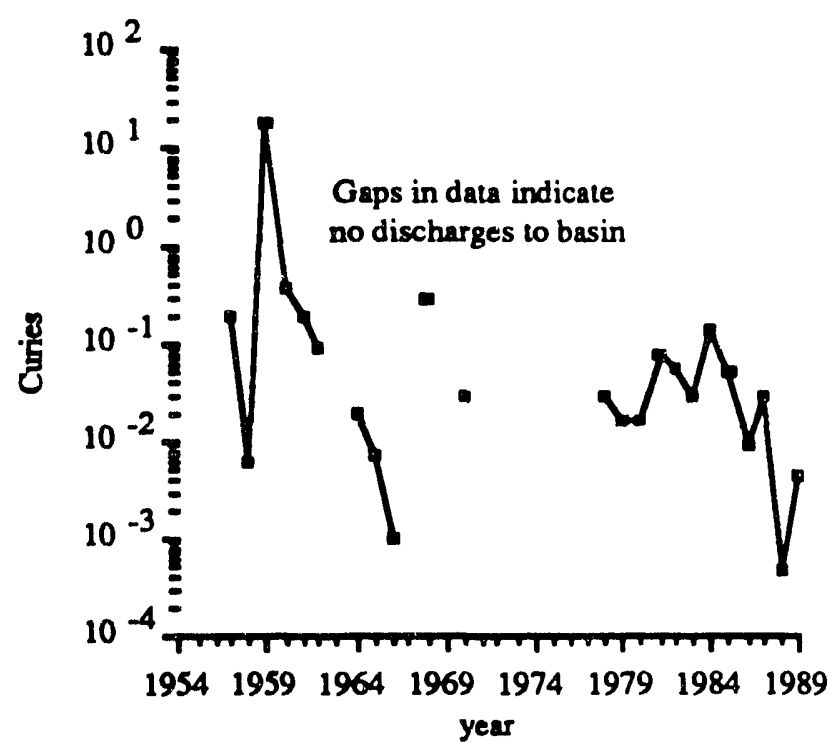

Figure 3-9. Cesium Releases to Seepage Basins, P Area 


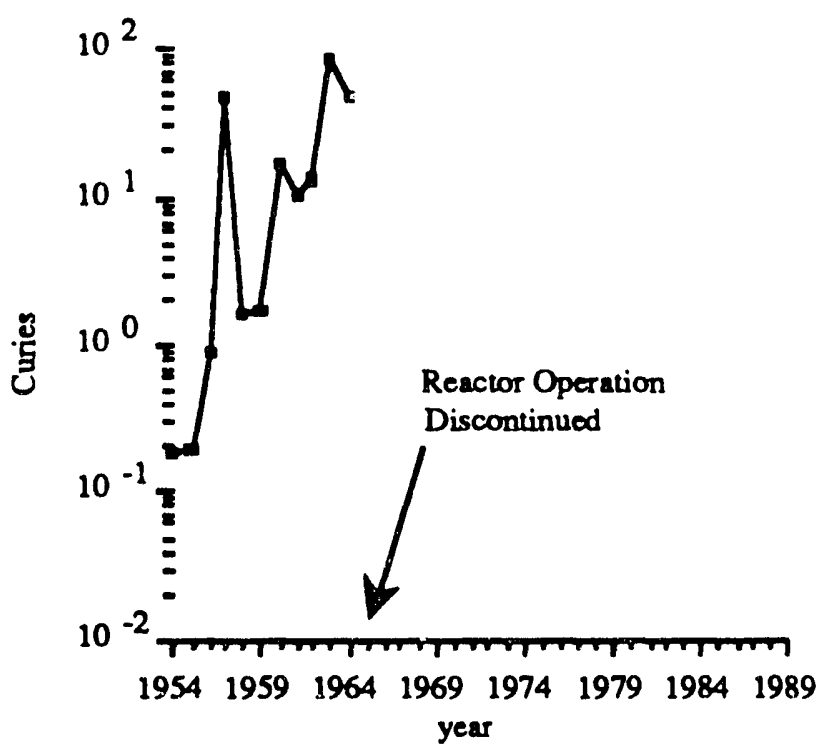

Figure 3-10. Cesium Releases to Streams, R Area

The original seepage basin, 904-103G, was used only from June to December 1957. Use of this basin was terminated because of surface outcropping and leakage into an abandoned sewer. The basin was backfilled in 1958. Basins 904-104G, -57G, -58G, and -59G were in use from 1957 to 1960. These four basins were deactivated, backfilled, and covered with asphalt in 1960. Basin 904-60 was in use from 1958 to 1964 and was backfilled in 1977.

Reactor heat exchanger cooling water and miscellaneous effluents were discharged to Lower Three Runs Creek from 1954 to 1958. After 1958, these effluents were discharged to Par Pond, which was constructed by the damming of Lower Three Runs Creek. Initially, $R$ Reactor effluents were discharged directly to Par Pond. Beginning in 1961, a canal and pond system that eventually drained into Par Pond (Figure 3-1 on page 3-1) replaced direct discharges into $\mathrm{Par}$ Pond.

The total measured releases of ${ }^{17} \mathrm{Cs}$ from $R$ Reactor to the Par Pond - Lower Three Runs system during its operational

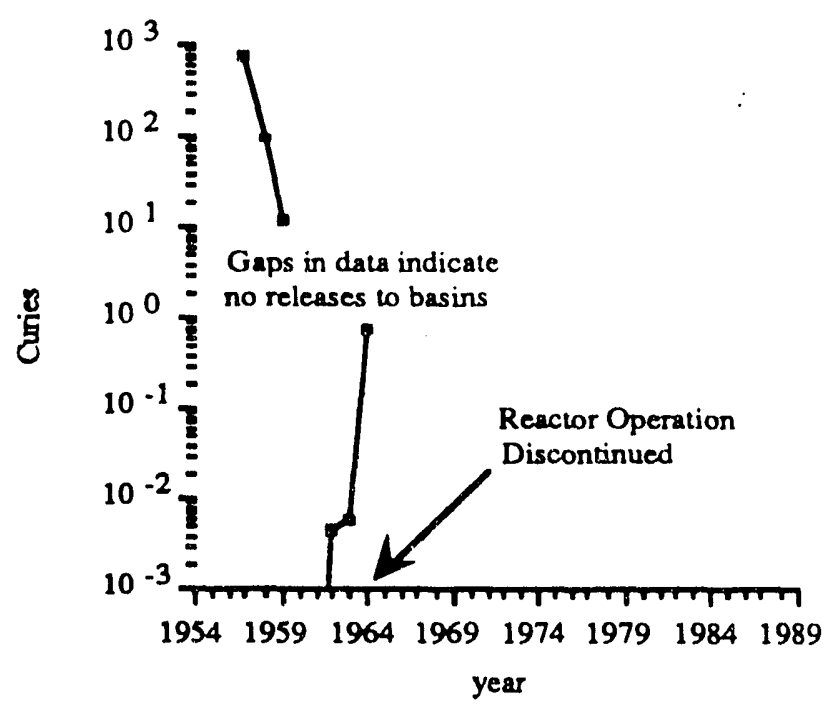

Fłgure 3-11. Cesium Releases to Seepage Basins, R Area

lifetime was 222.1 curies. An additional 900 curies was discharged to seepage basins. Most of the cesium releases to streams went into Par Pond. Stream $r$ leases from R Reactor are shown in Figure 3-10. The maximum annual release of 788 curies occurred in 1957 following the failure of an experimental fuel tube in the VTS isolation basin (see Figure 3-11). A total of about 47 curies of ${ }^{17} \mathrm{Cs}$ was released to Lower Three Runs Creek in 1957 as the result of the same incident. The maximum release to Par Pond, 83.4 curies, occurred in 1963 and resulted from a failed fuel tube stored in a leaking "harp".

\section{Summary of Reactor Releases}

The total measured aqueous release of ${ }^{134} \mathrm{Cs}$, ${ }^{137} \mathrm{Cs}$ from reactor areas through 1989 was 1502 curies. This consisted of 564 curies to site streams and ponds and 938 curies to seepage or containment basins. 


\section{Separations and Liquid Waste Facilities}

Two chemical separations facilities and their associated liquid waste storage facilities are located near the center of the site (Figure 3-1 on page 3-1). The two separations areas are identified by letter designations $\mathrm{F}$ and $\mathrm{H}$. In these areas the products of interest from reactor irradiation are chemically separated and purified from waste products. The greatest single release of radiocesium to the environment at SRS criginated from these facilities. Most of the radioactivity released in the incident soaked into soil, which was later removed to the Solid Waste Disposal Facility.

\section{Facility Operations}

The two chemical separations facilities were used to reprocess irradiated fuel and targets in canyon buildings (221-F and 221-H). Irradiated materials were dissolved and the products of interest were chemically separated and purified from waste fission and activation products. Occasional special campaigns for production of radionuclides such as ${ }^{200} \mathrm{Pu}$ and ${ }^{252} \mathrm{Cf}$ occurred.

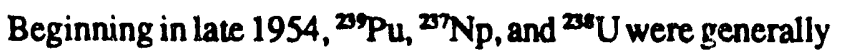
recovered from irradiated ${ }^{20} U$ targets in F Area, which used the Purex chemical extraction process. In $\mathrm{H}$ Area, ${ }^{20} \mathrm{Pu}$ and ${ }^{20} U$ were also recovered from ${ }^{20} U$ targets by the Purex process during 1955-1959. The H-Area facility was then modified to recover ${ }^{25} \mathrm{U}$ from irradiated enriched uranium fuel. A further modification in 1963 allowed the recovery of ${ }^{27} \mathrm{~Np}$ from the fuel. The HM process, which stood for $\mathrm{H}$ Modified Purex, was used for chemical extraction of the uranium. Also in H Area, the Frames process was occasionally used to recover ${ }^{20 \mathrm{Pu}}$ and ${ }^{27} \mathrm{~Np}$ from special target elements. This process used ion exchange for separation and purification.

Waste facilities in or adjacent to the separations facilities were designed for liquid waste handling. Depending on activity level, liquid wastes were stored in waste tanks or sent to either seepage basins or the Effluent Treatment Facility (ETF). In November 1988, the ETF became operational to treat the wastes that were previously sent to seepage basins. The scepage basins were closed in 1988 and have since been decommissioned.

\section{Pathways for Release}

Unlike the reactor facilities, which have released ${ }^{137} \mathrm{Cs}$ to the environment almost exclusively through aqueous effluents, the separations facilities have released radiocesium through atmospheric and aqueous effluents. While the aqueous releases from separations facilities have all been primarily to seepage basins, some radiocesium has been released to Four Mile Creek from leaks in cooling water lines and spills in the waste storage areas. Atmospheric releases of cesium have occurred from both the canyon building stacks and from vents in the waste storage tanks.

Aqueous releases occurred when residual radiocesium was present in high-level and low-level aqueous waste streams. Before these wastes were stored in tanks, an evaporation process was used to reduce volume. During evaporation, part of the radiocesium distilled with the condensate in the evaporators. This condensate was sent to the seepage basins prior to 1988. After 1988 the condensate was sent to ETF. Occasional leaks in cooling water coils in separations process vessels released small quantities of radioactivity to Four Mile Creek. The largest releases of cesium to Four Mile Creek from the separations areas resulted from rainwater washdown of soil contaminated from spills in the H Area waste storage facilities. This incident will be discussed in greater detail later in this chapter.

The disposition of various process waters from the separations facilities depended on the results of analyses of the water for radioactivity. Water was concentrated in evaporators prior to storage, sent to seepage basins or to the ETF, temporarily retained in basins, or released to site streams.

The major sources of wastewater previously discharged to the seepage basins were the overheads from the nitric acid recovery unit and the process evaporators in both $F$ and $H$ Areas. In $H$ Area, water from the Resin Regeneration Facility and Receiving Basin for Offsite Fuel (RBOF) was also discharged to the seepage basin system. A flow sheet for liquid waste handling can be found in the reference Jacobsen et al., 1973. Because of the date of this reference, it does not show that ETF has replaced the seepage basins. 


\section{Release Monitoring}

Atmospheric releases of ${ }^{17} \mathrm{Cs}$ from separations facilities have been quantified since startup in 1954. Reprocessing of irradiated material began in F Canyon in November 1954, and in H Canyon in July 195 j.

Aqueous releases of ${ }^{17} \mathrm{Cs}$ to seepage basins have also been quantified since startup. Specific radiochemical analyses for cesium in aqueous releases to stream were not begun until 1970. Liquid releases to streams were monitored for nonvolatile beta activity since startup, however. Several techniques were used to monitor aqueous releases. Process cooling water in F Area was monitored in-line for betagamma activity. In $\mathrm{H}$ Area, batches of process cooling water are monitored prior to release. When liquid effluents were released to seepage basins, they were continuously sampled. Samples were collected weekly and analyzed by gamma spectrometry. Specific radiochemical techniques were also used to analyze for radiocesium both before and after gamma spectrometry became common. Effluent Treatment Facility discharges are sampled prior to release to Upper Three Runs Creek.

\section{History of Measured Releases}

Atmospheric releases of ${ }^{137} \mathrm{Cs}$ as well as releases to seepage basins were quantified since the startup of the chemical separations facilities (Cummins et al., 1991). Releases to streams via process cooling water discharges were measured as nonvolatile beta since startup. Identification and quantification of the radiocesium contribution to these releases was not initiated until 1970.

The history of releases of radiocesium shows that approximately the same activity was released to the seepage basins from both F Area and H Area (about 200 curies from each area between 1954 and 1988 when the basins were closed). Except for two high release events in $\mathrm{H}$ Area, atmospheric releases of ${ }^{134} \mathrm{Cs}$ and ${ }^{17} \mathrm{Cs}$ are equivalent as well (about 0.6 curies from each area between 1954 and 1989 exclusive of the release events in $\mathrm{H}$ Area). The total releases of radiocesium in process cooling water were less that 1 curie for each area during their history of operation. Rainwater washdown of residual contamination from a high-level waste spill in $\mathrm{H}$ Area added nearly 42 curies of radiocesium to the activity discharged to Four Mile Creek between 1967 and 1988.

\section{F-Area Separations}

Aqueous wastes from $\mathrm{F}$ Canyon were initially sent to waste tanks and a seepage basin designated $904-49 \mathrm{G}$, also known as Old F Area Seepage Basin. The capacity of this basin proved to be inadequate and was abandoned in 1955 after three additional seepage basins were constructed. The new basins, designated $904-41 \mathrm{G},-42 \mathrm{G}$, and $-43 \mathrm{G}$, were in use from 1955 until 1988 when waste waters were divened to ETF. The latuer basins were also known as F Seepage Basins 1,2 , and 3 .

Additionally, an earthen retention basin (281-3F) was used from 1955 to 1973 for the temporary containment of water that was potentially contaminated by process upsets. Use of a lined retention basin was implemented in 1973.

\section{Releases to Streams}

Cooling water for portions of the F Area separation process is pumped from deep wells and discharged to Four Mile Creek after use. This water has been used in the "once through" or the "segregated" cooling water systems used to control temperatures in the separations process or waste evaporators. Because of the possibility of cooling coil leakage, these cooling water streams have the potential to contain measurable amounts of radioactivity. Cooling coils are used in the head end dissolvers; hence, a mixture of many fission and activation products is available as a potential contaminant of the cooling system.

In order to minimize releases of radioactivity into the cooling system when a leak does occur, positive pressure is maintained in the cooling coils in all process vessels. After the water has been used, it is monitored and released into Four Mile Creek. Should activity levels in the water preclude the discharge to the creek, the contaminated water is held in a plastic-lined "diversion" basin and transferred to either the H-Area waste tank farm or it is sent to the ETF for cleaning. In the past, water in the diversion basin, which was too radioactive for release to the stream, was pumped to the secpage basins.

Water from the cooling system is monitored prior to release to Four Mile Creek. From F-Area startup through 1969, this water was analyzed only for gross nonvolatile beta. No specific analyses were made for radiocesium. Specific analysis for ${ }^{14} \mathrm{Cs}$ and ${ }^{137} \mathrm{Cs}$ was initiated in 1970 . A total of 


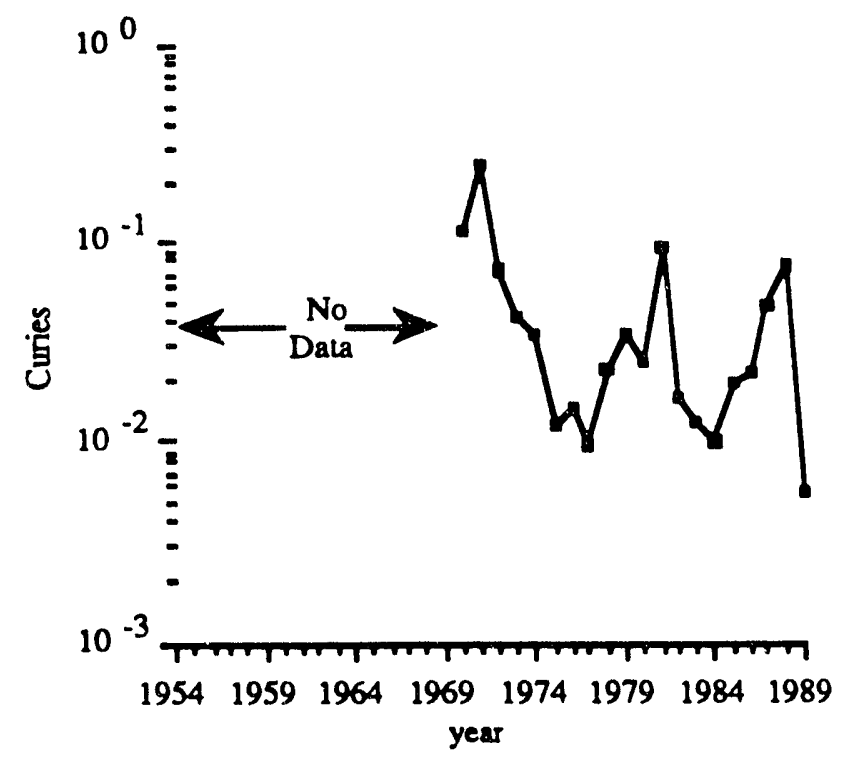

Figure 3-12. Cesium Releases to Streams, F Area

0.933 curies of cesium was released in the period 1970 through 1989, the maximum release of 0.25 curies occurred in 1971. Annual releases are shown in Figure 3-12.

\section{Releases to F-Area Seepage Basins}

The total measured aqueous release of radiocesium to the F-Area seepage basin system through 1988, when discharges to the seepage basins were terminated, was 221 curies. Measured annual releases of ${ }^{17} \mathrm{Cs}$ are shown in Figure 3-13. The maximum annual release, 57 curies, occurred in 1962.

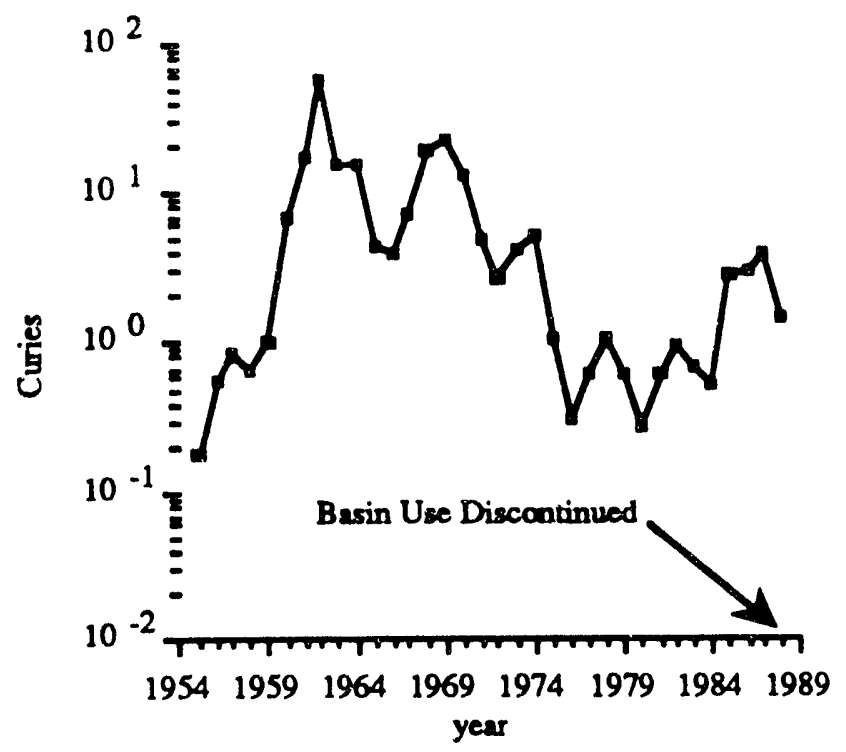

Figure 3-13. Cesium Releases to Seepage Basins, F Area

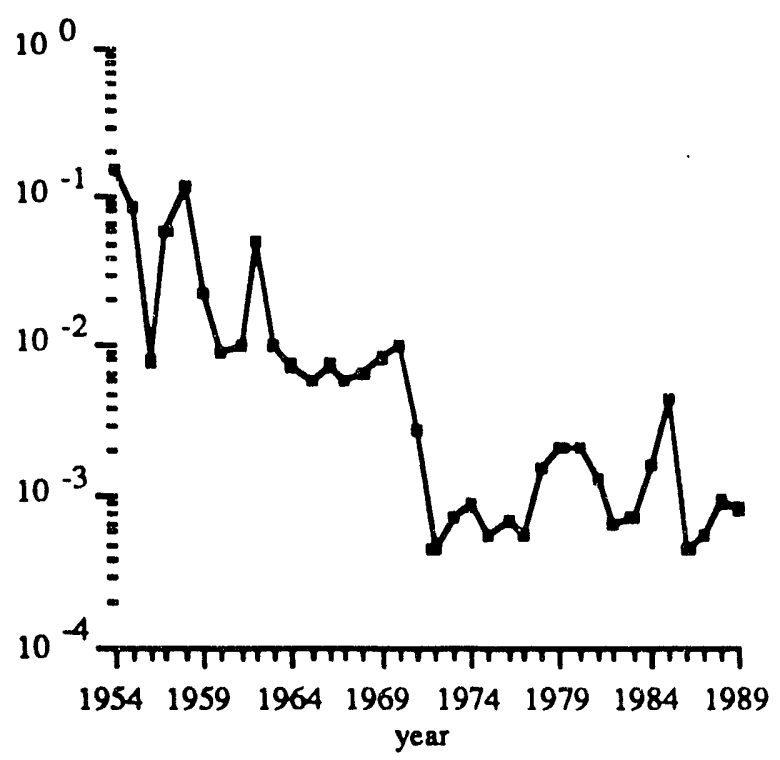

Figure 3-14. Cesium Releases to Atmosphere, F Area

Migration of radiocesium from the seepage basins to Four Mile Creek is minimal because of the high affinity of the cesium atom for clays in the soil (Grim, 1968). Some very small groundwater transport of colloidal cesium has been postulated, and given the name "facilitated transport". The quantity of radioactivity moving by this mechanism is too small to have an impact on measurable cesium transport in Four Mile Creek. Tritium migration studies show that groundwater containing wastes discharged to the F-Area seepage basin system flows into Four Mile Creek.

\section{Releases to Atmosphere}

The total measured atmospheric release of ${ }^{137} \mathrm{Cs}$ from F Area through 1989 was approximately 0.60 curies. Measured annual releases of radiocesium are shown in Figure 3-14. The maximum annual releases of 0.15 and 0.12 curies, occurred during startup in 1954 and in 1958 respectively.

\section{H-Area Separations}

H Canyon has been operational since July of 1955 . In addition to the general chemical separations operations, $\mathrm{H}$ Area also includes the Effluent Treatment Facility and Recciving Basin for Offsite Fuels (RBOF) with an adjacent regeneration facility for resins from other areas. Certain offsite noncommercial irradiated fuels are stored underwater in RBOF as are some SRS fuel elements that have failed. This facility is equipped to disassemble and cut fuel for inspection. 


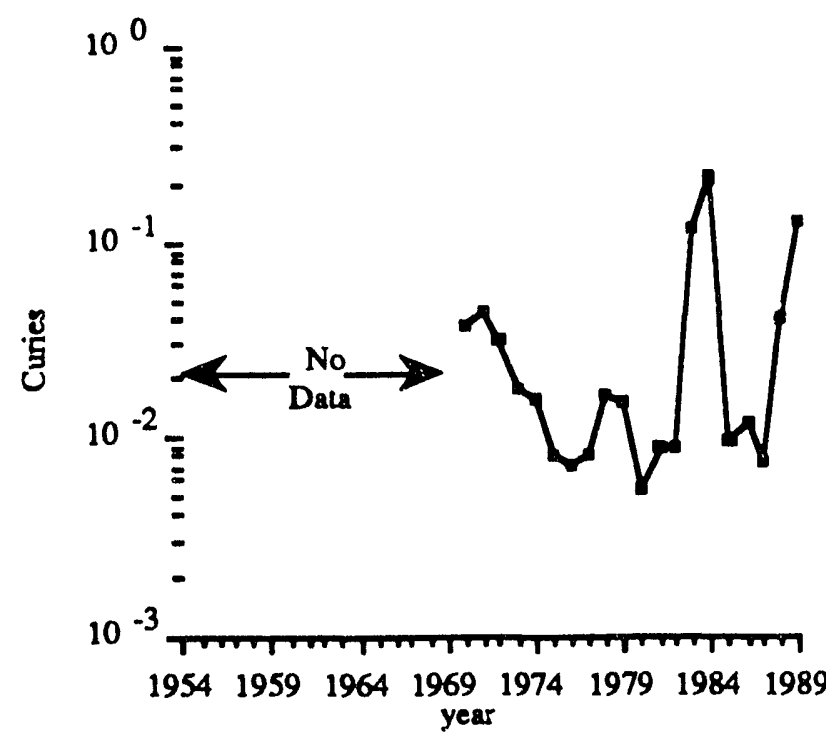

Figure 3-15. Cesium Releases to Streams, H Area

Aqueous wastes from $\mathrm{H}$ Canyon were sent to waste tanks and the four seepage basins designated 904-44G, -45G, $-46 \mathrm{G}$, and $-56 \mathrm{G}$. The basins, which were also kmown as $\mathrm{H}$ Seepage Basins 1, 2, 3, and 4, were in use from 1955 until 1988 when waste waters were diverted to ETF. Basin 904-46G has been inactive since 1962.

In addition, an earthen retention basin, designated 281-3H, was used from 1955 to 1973 to temporarily contain water that was potentially contaminated by process upsets. Use of a lined retention basin was implemented in 1973.

\section{Releases to Streams}

As in F Area, clean well water is pumped through pressurized coils in evaporators and process tanks to control temperatures, then discharged into a process sewer which empties into Four Mile Creek. Water from the cooling system is monitored prior to release to Four Mile Creek. From $H$ Area startup through 1969, this water was analyzed for gross nonvolatile beta only: no specific analyses were made for radiocesium. Specific analysis for ${ }^{134} \mathrm{Cs}$ and ${ }^{137} \mathrm{Cs}$ was initiated in 1970. A total of 0.75 curies of cesium was released in the period 1970 through 1989, the maximum release of 0.21 curies occurred in 1984. Annual releases are shown in Figure 3-15.

By far the largest amount of cesium released from $H$ Area to Four Mile Creek resulted from a high-level waste spill in the waste storage area. Pluggage of a high-level waste line into one of the storage tanks in May 1967 resulted in a spill of an estimated 1500-2000 curies of activity onto the ground. Most of this activity was ${ }^{13} \mathrm{Cs}$ and ${ }^{17} \mathrm{Cs}$ thet had been reconcentrated by evaporation. Most of the spilled radioactivity seeped into the soil and was later removed to the Solid Waste Disposal Facility. Some of the activity reached a storm sewer which normally flows into Four Mile Creek, but a hastily erected earthen dam across the effluent channel prevented liquid from discharging directly to the stream. Liquid from the storm sewer was later pumped to the seepage basin (Ashley, 1968). Some of the cesium reacted with clays in the soil in the spill area and along the storm sewer route. While the bulk of the contaminated soil was removed to the Solid Waste Disposal Facility rainwater flowing over the area later washed residual activity into Four Mile Creek. Analysis of creek water collected routinely from a sample point below the outfall of the storm sewer indicated as much as 32 curies of radiocesium washed into the Four Mile Creek in 1967 after the spill. Because most of the cesium was associated with soil and sediments, only about 1 curie remained in transport by the time the stream flowed past the Road A sample point (the last onsite stream sampling location before flowing into the swampy area along the river contiguous to the plant) (Ashley, 1967). Residual activity continued to wash into the stream over a period of several years but at greatly diminished rates. By 1989, the concentration of cesium at the storm sewer outfall was below the lower limit of detection. Annual transport of cesium in Four Mile Creek from this streambed washdown or "desorption" is shown in Figure 3-16.

\section{Releases to Seepage Basins}

The total measured aqueous release of ${ }^{134} \mathrm{Cs}$ and ${ }^{137} \mathrm{Cs}$ to the H-Area seepage basin system through 1988, when dis-

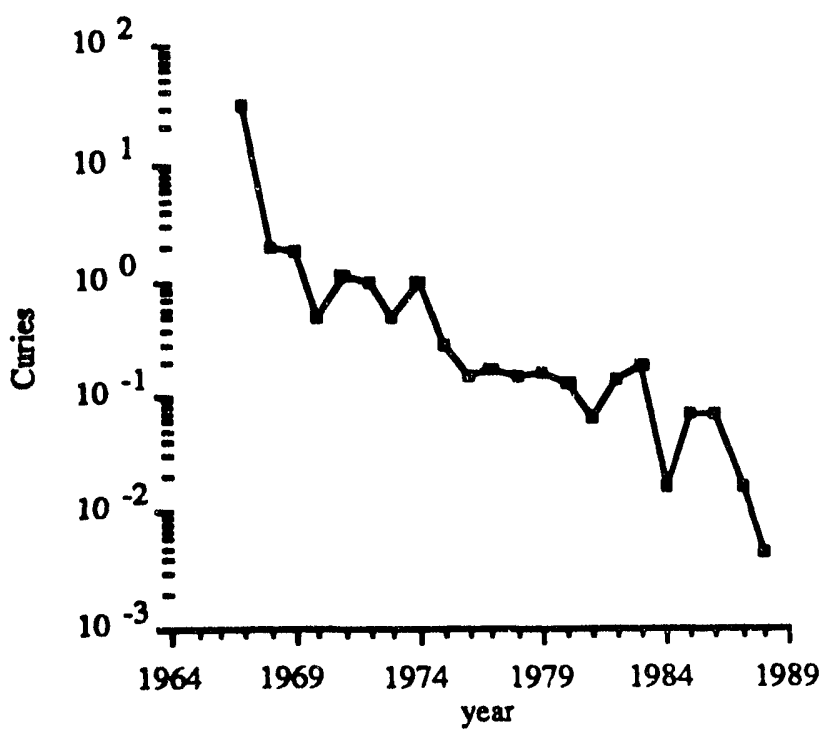

Figure 3-16. Cesium Releases from "Streambed Desorption" 


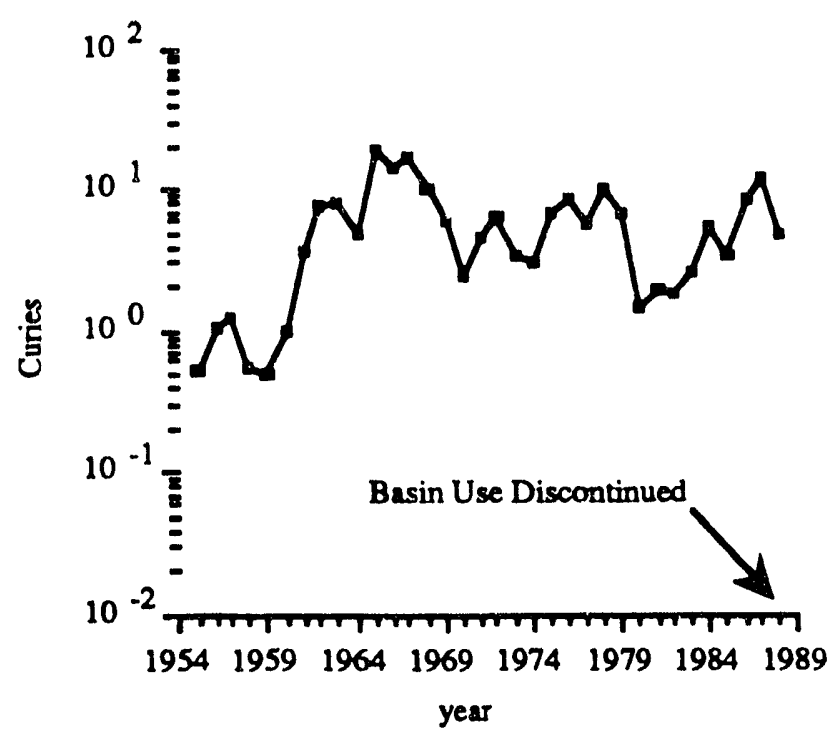

Figure 3-17. Cesium Releases to Seepage Basins, H Area

charges to the seepage basins were terminated, was 194 curies. Measured annual releases are shown in Figure 3-17. The maximum annual release of 19.7 curies occurred in 1965.

Elevated levels of ${ }^{14} \mathrm{Cs}$ and ${ }^{17} \mathrm{Cs}$ have been detected in surface outcrops of groundwater into Four Mile Creek near the H-Area basin system (Haselow et al., 1990). Movement of some cesium in groundwater near the $H$ Area system is probably facilitated by low $\mathrm{pH}$ water seeping out of the basin in highly permeable channels to outcrop areas as close as a few hundred yards from the basin system. The phenomenon of "facilitated transport" may also play a role in the elevated levels of cesium. In any event, the levels of activity in the stream are below the primary drinking water standards $(<0.2 \mathrm{pCi} / \mathrm{ml})$.

The F- and $\mathrm{H}$-Effluent Treatment Facility became operational in November 1988 to receive aqueous wastes previously discharged to the separations area seepage basins.

\section{Releases to A tmosphere}

Two facilities located in $\mathrm{H}$ Area have contributed to significant releases of radiocesium to the atmosphere. These are the $\mathrm{H}$ Canyon and the high-level waste storage facilities. Two additional H-Area facilities (RBOF and ETF) handle significant inventories of radiocesium, but because the radioactivity is contained in fuel assemblies or is in solution, the potential for airbome release is very low.

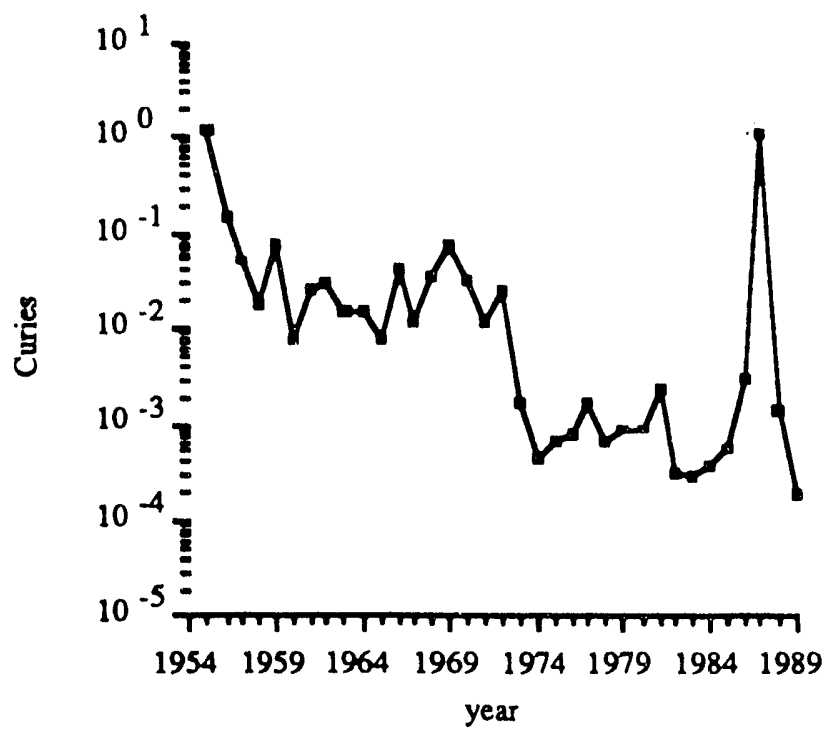

Figure 3-18. Cesium Releases to Atmosphere, H Area

The total measured atmospheric release of ${ }^{134} \mathrm{Cs}$ and ${ }^{17} \mathrm{Cs}$ from $\mathrm{H}$ Area through 1989 was 2.95 curies, most of which was released in 1955 during startup (1.2 curies-primarily as a result of leakage around the sand filter bypass plug), and in 1987 when an evaporator steam flange failed in the waste management facility (1.1 curies). Measured annual releases are shown in Figure 3-18.

\section{Emuent Treatment Facility}

All the low-level liquid wastes formerly discharged to the F-and H-Area seepage basins are now processed in the ETF. Treated aqueous wastes from the ETF are discharged to Upper Three Runs Creek. The measured stream release of radiocesium for 1989 , the first year of operation, was 0.068 curies.

\section{Waste Tank Farms}

High-level radioactive liquid waste storage tanks, located in both $\mathrm{F}$ and $\mathrm{H}$ Areas, are known to contain large inventories of the cesium isotopes ${ }^{134} \mathrm{Cs},{ }^{133} \mathrm{Cs}$, and ${ }^{137} \mathrm{Cs}$. The ${ }^{134} \mathrm{Cs}$ is not a direct fission product but is formed by neutron capture by stable ${ }^{133} \mathrm{Cs}$ generated in the reactor fuel. Isotope ${ }^{134} \mathrm{Cs}$ has a half-life of 2.06 years and has a complex decay scheme including gamma emission energies of 0.8 and $0.6 \mathrm{MeV}$. Isotope ${ }^{13} \mathrm{Cs}$ has a half-life of $2.3 \times 10^{6}$ years, and decays by beta decay with no gamma emission. Because of its low specific activity and relatively low beta energy (Emax = $0.21 \mathrm{MeV}{ }^{135} \mathrm{Cs}$ is not a significant contributor to popula- 
tion doses. (It is formed with essentially the same mass yield as ${ }^{17} \mathrm{Cs}$ but is 100,000 times less radioactive.) Isotope ${ }^{17} \mathrm{Cs}$ has a 30-year half-life, is formed with a mass yield of about $6.2 \%$, and decays by beta emission to form ${ }^{17} \mathrm{~m} \mathrm{Ba}$, which, in turn, emits a $0.661 \mathrm{MeV}$ gamma photon in decaying to ground state. Cesium salts are highly soluble in water, thus the supemate in the waste storage tanks contains most of the inventory of cesium. The total inventory of ${ }^{137} \mathrm{Cs}-{ }^{137} \mathrm{Ba}$ in the waste tanks has been estimated to be $2.6 \times 10^{3} \mathrm{Ci}$ as of December 1990 (DOE, 1991).

Radioactivity is known to have leaked into the ground from waste tanks on at least two occasions. In 1960, H-Area Tank 16 developed a leak that overfilled the saucer under the tank. Some high-level waste seeped into the surrounding soil. The exact amount of waste escaping into the soil is unknown, but best estimates indicate about $100 \mathrm{Ci}$ of ${ }^{137} \mathrm{Cs}$ was released to the ground. Monitoring wells indicate that movement of the cesium is very slow, and, in fact, is still confined to the tank farm area (Poc, 197/). In 1961, F-Area Tank 8 was inadvertently overfilled resulting in an estimated $5000 \mathrm{Ci}$ release of ${ }^{137} \mathrm{Cs}$ to the soil surrounding the buried transfer line. Again, monitoring wells show that the cesium has not migrated away from the spill site. (Odum, 1976).

\section{Summary of Separations and Liquid Waste Facilities}

Measured aqueous releases of radiocesium from the separations areas total 458 curies between 1954 and 1989, 414 curies of which went to seepage basins and 44 curies of which went into Four Mile Creek. Of the 44 curies released to the stream, 42 curies resulted from rainwater washdown of activity spilled in the waste handling area. The combined total atmospheric releases of radiocesium was about $3.5 \mathrm{Ci}$. 


\section{Solid Waste Disposal Facility}

Radioactive solid wastes generated during the operation of the Savannah River Site have been burned in the low-level waste incinerators or buried in the Solid Waste Disposal Facility (formerly called the Burial Ground). Because of the nature of much of the waste, precise analysis of the radioactive inventory of materials committed to the Solid Waste Disposal Facility is not available. Estimates of the radioactive content of packaged wastes are made from radiation surveys of the packages, and conversion factors applied based on known or assumed fission product content. The data on each package are recorded at the burial facility and a computerized inventory is maintained. Based on these data, the estimated "decay corrected" cesium content of the Solid Waste Disposal Facility was 1,809 curies as of January 1987 (Harrell, 1988). 


\section{Savannah River Laboratory}

Savannah River Laboratory (SRL) provides research and development support for the production facilities of SRS. Laboratory facilities handle radioactivity that ranged from environmental levels to highly radioactive material that was manipulated in shielded cells.

Liquid radioactive wastes have been accumulated in holding tanks pending shipment to $F$ Area for treatment and disposition.

From 1954 to 1982, a seepage basin system was used for low-activity wastes. The first two seepage basins, both designated 904-53G, were placed into service in 1954. The last two basins, 904-54G, and -55G, were added in 1958 and 1960. Analyses of activity released to the basins was limited to non-volatile beta activity until 1974. Radiocesium releases to the SRL basins totaled $11 \mathrm{mCi}$ between 1974 and 1982 when basin use was discontinued. See Figure 3-19 for summary of release activity from SRL.

Atmospheric releases of radiocesium from SRL were reported only for the year 1979 , when $2.6 \mathrm{mCi}$ was released.
$3 e-3-$

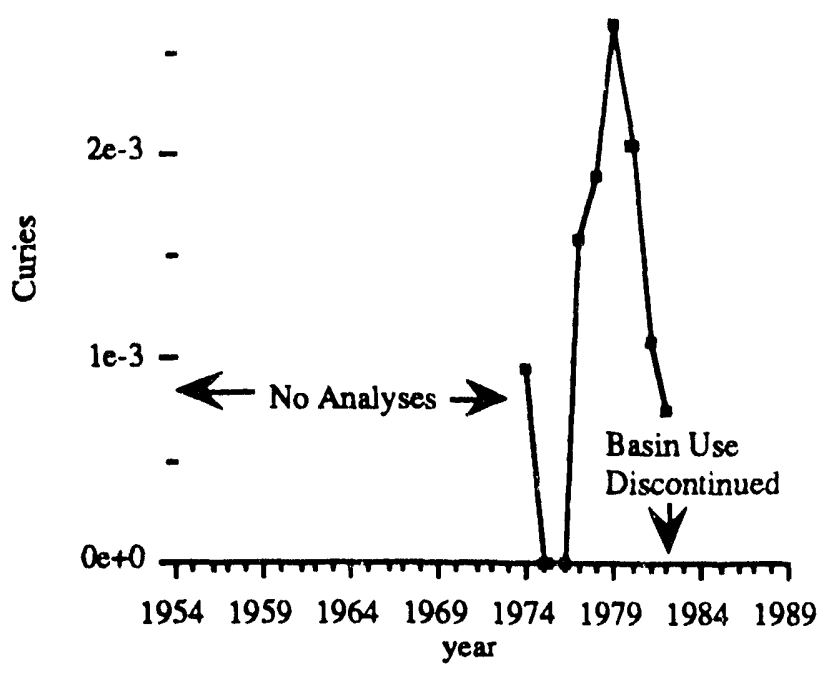

Figure 3-19. Cesium Releases to Seepage Basins, SRL 


\section{Other Facilities}

All documented radiocesium releases from SRS facilities were listed in the previous sections. A number of other facilities handled materials containing radiocesium. These were the test reactors, the Heavy Water Rework Facility, and any facility handling spontaneously fissioning elements.

No releases of radiocesium were documented for any of the test reactors described in Chapter 2. Had there been releases from these facilities, the releases would have been small compared to the releases from production reactors. Operation of these test reactors was discontinued in the 1970s.

The Heavy Water Rework Facility, located in D Area, consisted of four distillation towers and associated equipment for removal of ordinary water that accumulated in the heavy water moderator used in the reactors. Leaks in the system were vented through a 21-meter stack. The aqueous waste stream was sent to Beaver Dam Creek after verification that activity levels did not exceed specific limits. The predominant radioactivity associated with this facility was tritium (see Figure 3-20).

There was a potential for traces of radiocesium to be present in the moderator, as was described in the section on reactor facilities. No specific monitoring for radiocesium is performed because of the relatively low potential for a release.

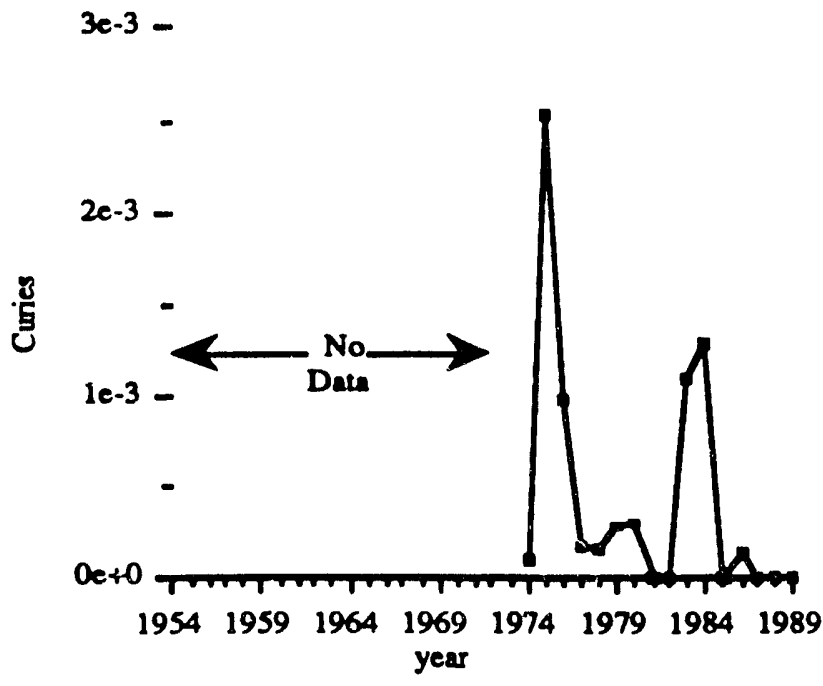

Figure 3-20. Cesium Releases to Streams, D Area
Central Shops at SRS is responsible for fabrication and repair of equipment that is used in the separations and reactor areas of the site. Though equipment was decontaminated before it is sent to Central Shops, some radioactive material occasionally was present and was normally removed during cleaning operations prior to repair of the equipment. The contamination was transferred along with other liquid waste streams to a seepage basin. The yearly releases of cesium to the basin are shown in Figure 3-21. The Central Shops seepage basin (sometimes referred to as the Ford Basin) is no longer in use.

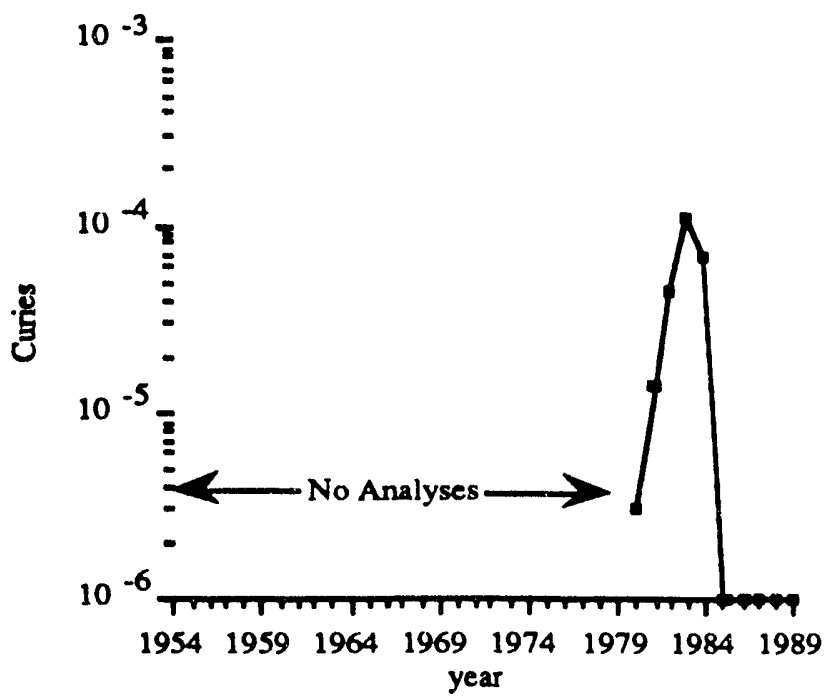

Flgure 3-21. Cesium Releases to Seepage Basins, Central Shops

Facilities, other than those already described in this chapter, that handle spontaneously fissioning elements were the reactor material facilities for uranium fuel and target fabrication in M Area, the TNX Semi-Works (where various processes were tested on a pilot scale with uranium) and the Naval Fuels facility (where uranium fuel for the US Navy was fabricated from the late 1980s until shutdown in 1989). The presence of low levels of radiocesium due to spontaneous fission had no impact on operations because the radiocesium was contained within the uranium metal; therefore, radiocesium in this case is only of academic interest. 


\section{Summary}

Total ${ }^{17} \mathrm{Cs}$ releases to streams and basins peaked in the early years of site operation (see Figures 3-22 and 3-23). Improvements in the process operations of facilities particularly reactors, have resulted in at least a factor of 100 reduction in releases.

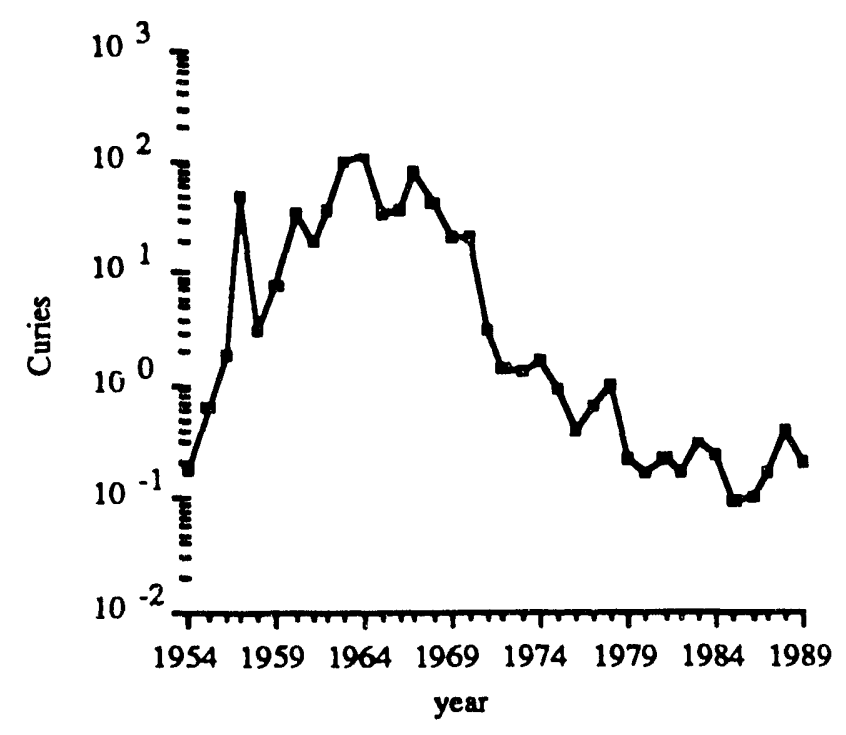

Figure 3-22. Cesium Releases to Streams, All Sources

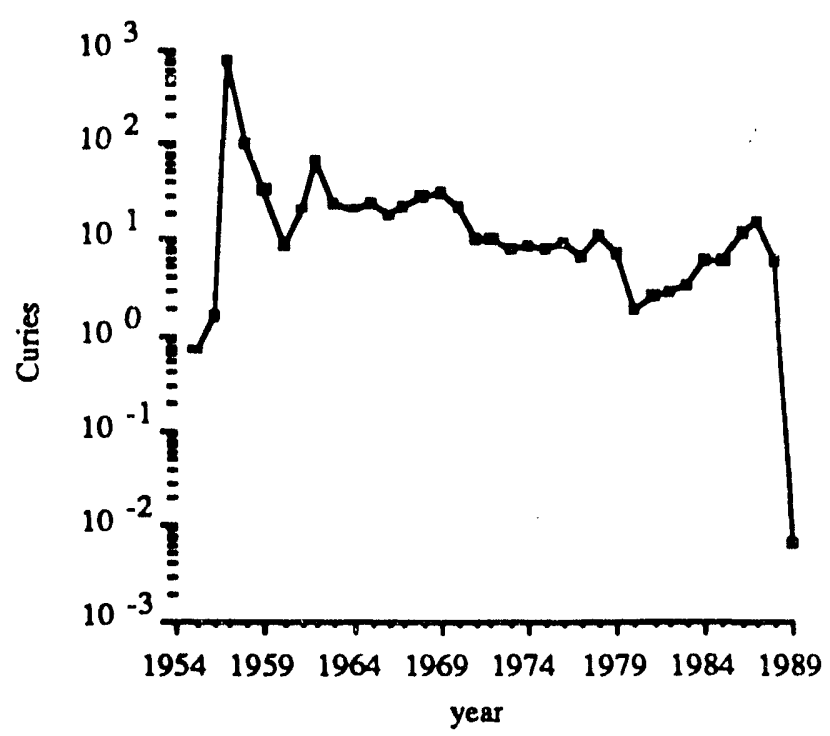

Figure 3-23 Cesium Releases to Seepage Basins, All Sources 


\section{References}

Ashley, C., 1968, "Environmental Monitoring at the Savannah River Plant, Annual Report 1967", DPSP-68-302, E. I. du Pont de Nemours and Company, Aiken, SC.

Cummins, C. L., C. S. Hetrick, and D. K. Martin, 1991, "Radioactive Releases at the Savannah River Site 1954-1989", WSRC-RP-91-684, Westinghouse Savannah River Company, Aiken, SC.

Harrell, S.J., C. D. Collier, and D. H. Walker, 1988, "Safety Analysis-200 Area Savannah River Plant Burial Operations", DPSTSA-200-10, Supp. 8, prepared by Science Applications International Corporation for E.I. du Pont de Nemours and Co, Aiken, SC.

Haselow, J. S., M. Harris, B. B. Looney, N. V. Halverson, and J. B. Gladden, 1990, "Analysis of Soil and Water at the Four Mile Creek Seepline near the F\&H Areas of SRS (U)", WSRC-RP-90-0591, Westinghouse Savannah River Company, Aiken, SC.

Jacobsen, W. R., W. L. Marter, D. A. Orth, and C. P. Ross, 1973, "Control and Treatment of Radioactive Liquid Waste Effluents at the Savannah River Plant", DP-1349, E. I. du Pont de Nemours and Company, Aiken, SC.

Jaegge, W. J., N. L. Kolb, B. B. Looney, I. W. Marine, O. A. Towler, and J. R. Cook, 1987, "Environmental Information Document, Radioactive Waste Burial
Grounds", DPST-85-694, E. 1. du Pont de Nemours and Company, Aiken, SC.

Killian, T. H., N. L. Kolb, P. Corbo, and I. W. Marine, 1985a, "Environmental Information Docuinent--F Area Seepage Basins", DPST -85-704, E. I. du Pont de Nemours and Company, Aiken, SC.

Killian, T. H., N. L. Kolb, P. Corbo, and I. W. Marine, 1985b, "Environmental Information Document-H Area Seepage Basins", DPST-85-706, E. I. du Pont de Nemours and Cornpany, Aiken, SC.

Odum, J. V., 1976, "Soil Contamination Adjacent to Waste Tank 8", DPSPU-76-11-4, E. I. du Pont de Nemours and Company, Aiken, SC.

Poe, W. L., 1974, "Leakage from Waste Tank 16". DP-1358, E. I. du Pont de Nemours and Company, Aiken, SC.

Taylor, R. W., 1989, "Effluent Treatment Facility Emissions Monitoring", DPST-89-309, E.I. du Pont de Nemours and Company, Aiken, SC.

U.S. Department of Energy, 1991, Integrated Data Base for 1991: U.S. Spent Fuel and Radioactive Waste Inventories, Projections, and Characleristics, DOE/ RW-0006, Rev 7, Prepared by Oak Ridge National Laboratory, Oak Ridge, TN. 


\section{Chapter 4. \\ Radiocesium Concentration and Transport Mechanisms}

Most of the radiocesium environmental measurements reported in this chapter are for ${ }^{13} \mathrm{Cs}$. Routine measurements for ${ }^{134} \mathrm{Cs}$ began in the early 1970 s. Other isotopes of cesium contribute significantly less dose in the environment and have not been routinely monitored. 


\section{Atmospheric Concentrations and Transport}

\section{Concentration of ${ }^{137} \mathrm{Cs}$ in Air}

Radionuclide ${ }^{17} \mathrm{Cs}$ in air is associated with suspended particles. The concentration is measured by filtering known amounts of air drawn from the atmosphere and counting the ${ }^{13} \mathrm{Cs}$ disintegrations. Air is sampled at a number of locations within the site perimeter, at two rings of sampling stations, one along the Savannah River Site (SRS) perimeter and the other about $40 \mathrm{~km}$ from the center of the site, and at four sampling stations located approximately $155 \mathrm{~km}$ from the the site center.

Sources of ${ }^{137} \mathrm{Cs}$ in the air include

- direct failout from nuclear bomb testing which occurred from 1945 until the end of atmospheric testing in 1980

- ${ }^{137} \mathrm{Cs}$ releases from other nuclear installations

- resuspension of ${ }^{13} \mathrm{Cs}$ particles deposited in the soil from past bomb related releases

- $S R S{ }^{17}$ Cs releases

SRS releases are very small relative to the ${ }^{137} \mathrm{Cs}$ released into the atmosphere by nuclear bomb test detonations.

The contribution of SRS to ${ }^{137} \mathrm{Cs}$ concentrations in the air can be assessed in two ways. The first is to plot the average

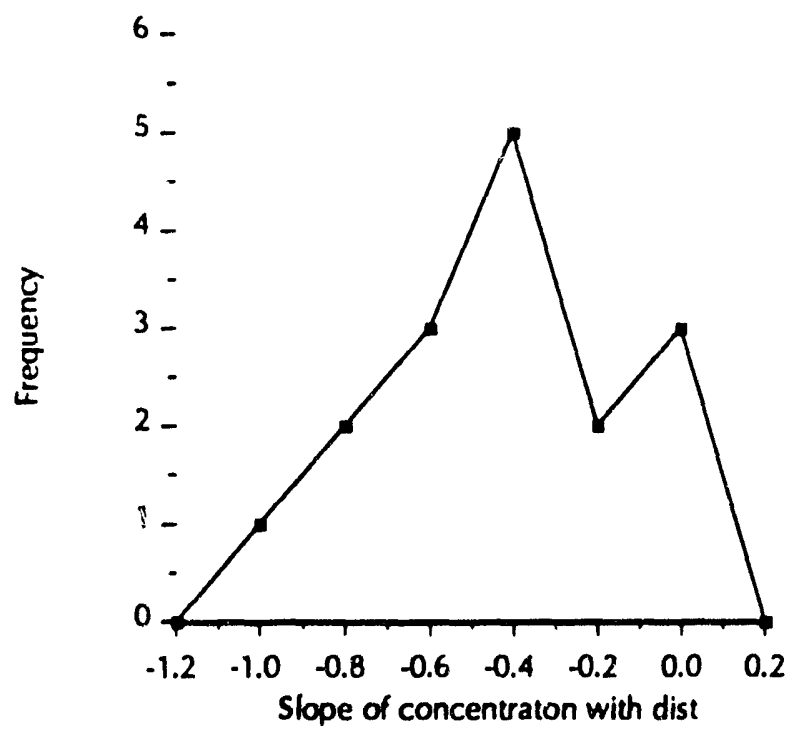

Figure 4-1. The Frequency Distribution of the Slope of the Logarithm of Air Corcentration vs. the Logarithm of Distance from SRS concentration measured at the sampling locations against the distance from SRS. If SRS has a measurable effect on the air concentration, the concentration should decrease with distance from the site. The second method is to compare the year-to-year variation in SRS releases with the air concentration in the vicinity of the site. If SRS makes a significant contribution to the air concentration, the concentration should rise and fall with the quantity of ${ }^{13} \mathrm{Cs}$ released from the site.

Simple diffusion theory suggests that the average concentration of ${ }^{137} \mathrm{Cs}$ in air ploted against the distance from the source of the ${ }^{17} \mathrm{Cs}$ release should be a straight line when plotted in logarithmic coordinates. Furthermore, if the distance from the source is great enough that there is little effect of the release height, then the slope of this line will be -1.0. Figure 4-1 shows the distribution of the slope of the straight line for the years when ${ }^{137} \mathrm{Cs}$ air samples are available. The results suggest that the contribution of SRS on the ${ }^{137} \mathrm{Cs}$ concentration in air can be detected during many of the years when measurements are available.

Figure 4-2 shows the average ${ }^{177} \mathrm{Cs}$ concentration measured in the vicinity of SRS (the site perimeter average is used) and the two major factors assumed to influence the cesium air concentration near the site, the releases from SRS and the explosive yield of nuclear bombs detonated during this period (one megaton TNT equivalent, ML, releases approximately $160,000 \mathrm{Ci}$ of ${ }^{137} \mathrm{Cs}$ ). The concentration of ${ }^{7} \mathrm{Be}$, a natural, stratospherically produced radionuclide, is also shown because of its potential as an index of exchange between the stratosphere, where most bomb-related ${ }^{13} \mathrm{Cs}$ was released, and the earh's surface where the SRS measurements were taken. Because of the great variation in the factors affecting the ${ }^{15} \mathrm{Cs}$ concentration and the air concentration itself, it is difficult to find relationships between the annual variation in the factors and in the concentration.

One approach to determining the relative effect of the factors contributing to the ${ }^{17} \mathrm{Cs}$ air concencration is linear regression modeling. This approach assumes that the annual average air concentration is proportional to the $S R S$ releases and the atmospheric test detonation releases averaged over a number of years after each detonation. The effect of atmospheric detonations are assumed to affect the surface concentration over a number of years because of the travel ime from the stratosphere to the surface. SRS releases are 


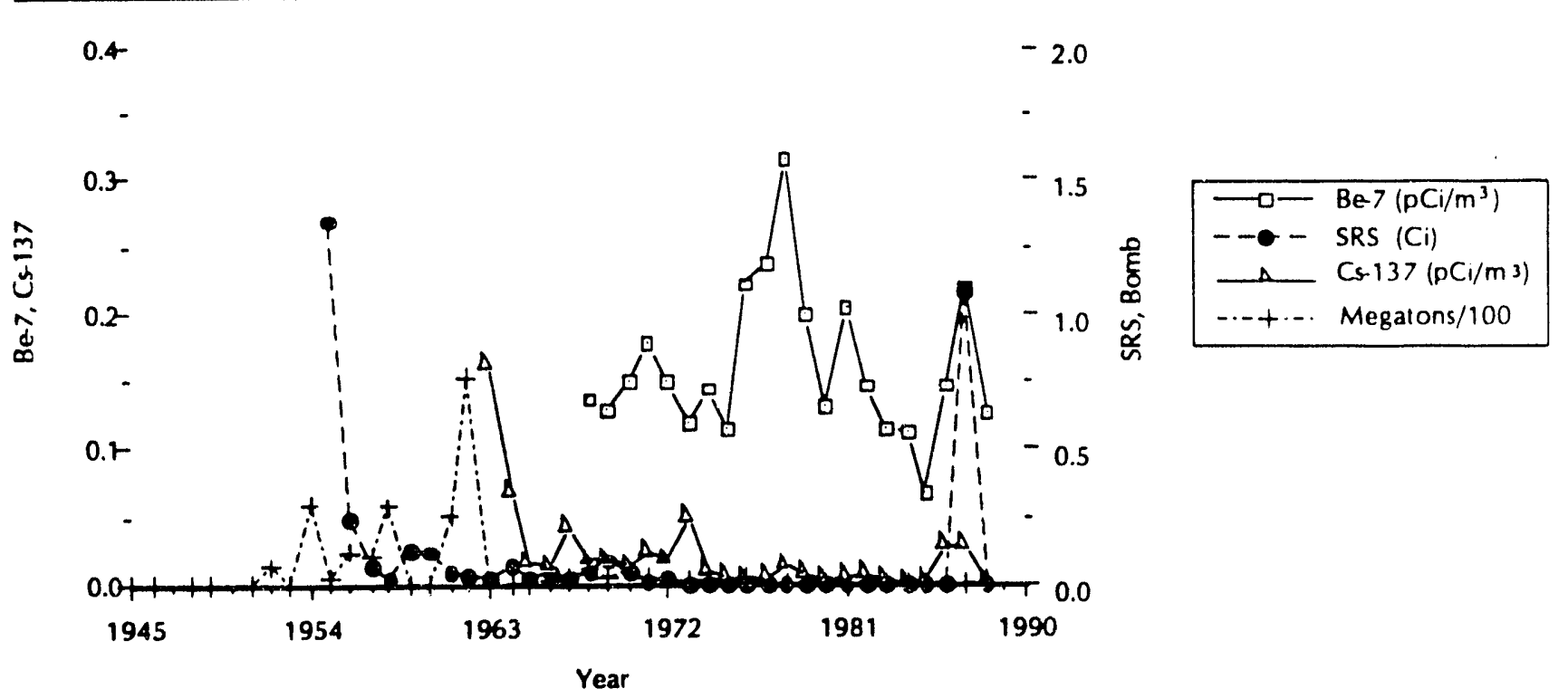

Figure 4-2. ${ }^{15} \mathrm{Cs}$ Concentration in the Atmosphere Compared to Nuclear Explosive Yields, SRS Releases, and Natural ${ }^{7} \mathrm{Be}$ Concentrations

assumed to affect the concentration immediately because they are released at the surface.

The results of this analysis are shown in Figures 4-3 and 4-4. Figure 4-3 compares the concentrations predicted by the linear regression and those measured at SRS. It was found necessary to include the effect of the Chernobyl accident to predict the concentrations in 1986. The best regression model, in terms of predicting the SRS ${ }^{137} \mathrm{Cs}$ air concentration included contributions of bomb fallout for four years following the detonation. The largest contribution was

$0.2-$

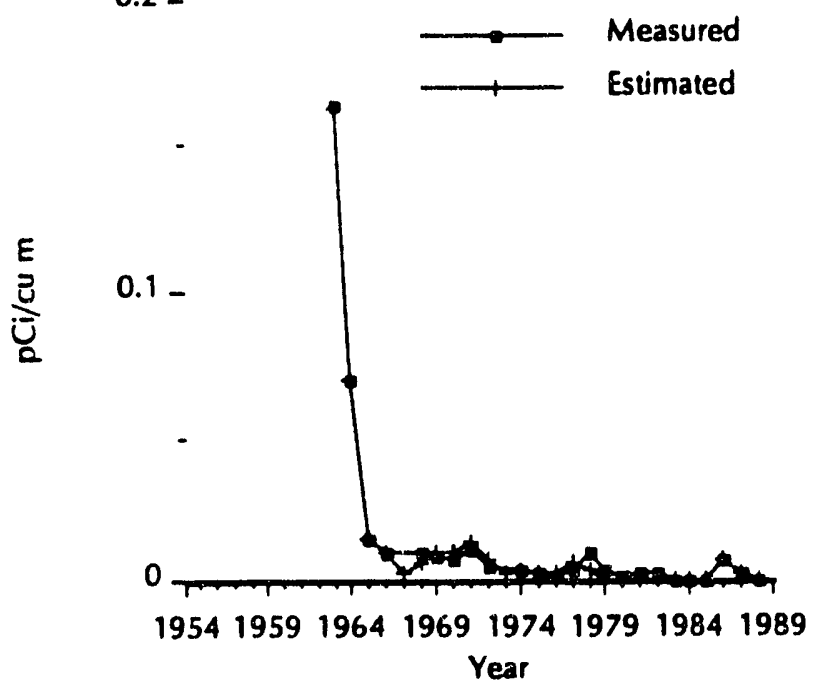

Figure 4-3. Measured ${ }^{137} \mathrm{Cs}$ Air Concentration vs. Air Concentration Calculated with a Regression Model Using Bomb Yields, SRS Releases and Chemobyl Releases forecast for the year following the detonation. This agrees with the fact that the physical exchange between the stratosphere and the troposphere takes place in the spring of most years and exchange is very low at other times of the year. Therefore, much of the exchange from detonations in one year occurs in the spring of the next year.

The regression model allows an estimate of the contribution from each of the sources of ${ }^{137} \mathrm{Cs}$. The relationship developed from the analysis has also been used to estimate the effect of SRS on air concentration for the years before

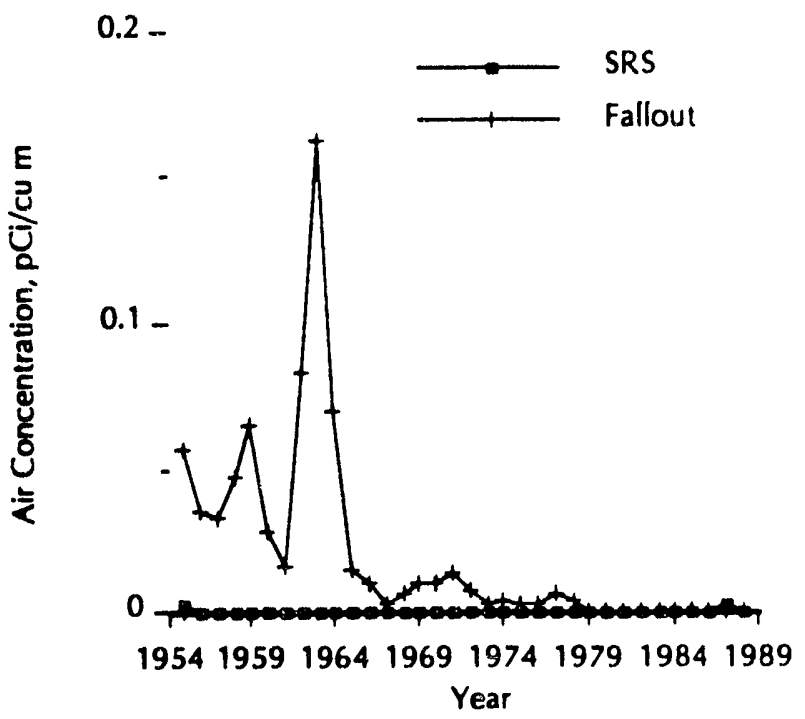

Fqure 4-4. Estimate of the Relative Contribution of Bomb Yield ${ }^{137} \mathrm{Cs}$ and SRS Releases 
measurements were made. Figure $4-4$ shows the results of the regression analysis for the entire period of SRS operation. It is obvious that the contribution due to SRS releases is very small when compared to the contribution from weapons tests. After suspension of weapons tests, the measured levels are very low. Even following the Chernobyl accident in 1986 and an inadvertent release from SRS to the atmosphere in 1987, the atmospheric levels were much lower than those measured during the period of weapons tests.

\section{Deposition of ${ }^{137} \mathrm{Cs}$ in Rainwater}

Deposition of radionuclides in rainwater is determined by collecting the water in a rain gage. A sample of the rainwater is counted by gamma analysis for ${ }^{137} \mathrm{Cs}$. The results are reported in the amount of ${ }^{137} \mathrm{Cs}$ deposited per unit of area per unit of time ( $\left.\mathrm{nCi} / \mathrm{m}^{2} / \mathrm{yr}\right)$.

Since the deposition of ${ }^{17} \mathrm{Cs}$ in rainwater is caused by the removal of particles from the air during rainfall, it is reasonable to assume that the deposition would be related to the air concentration. However, rainfall events occur during a small fraction of time during a year. Since the SRS releases of ${ }^{137} \mathrm{Cs}$ to the atmosphere are not constant throughout the year, it is possible that the sampling pattem of the rain gages will not coincide with the sampling pattem of the continuous air monitoring samplers. As shown in Figure 4-5, in most years there appears to be little relationship between ${ }^{157} \mathrm{Cs}$ deposition and distance from SRS. As indicated above, this contrasts with the case of air concentration.

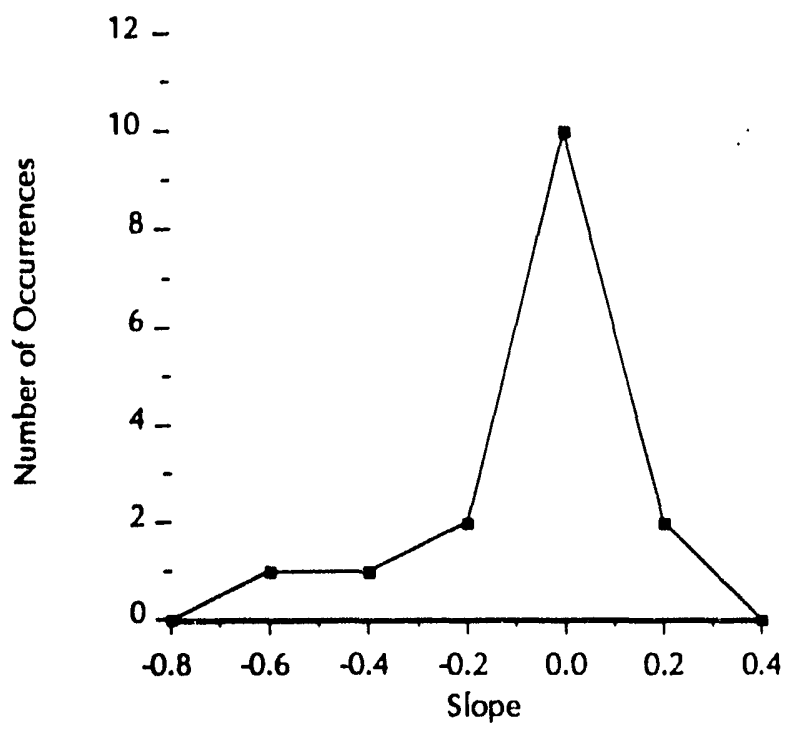

Figure 4-5. The Distribution of the Slope of the Logarithm of the ${ }^{13} \mathrm{Cs}$ Deposition in Rainfall and the Logarithm of Distance from SRS

Figure 4-6 shows the variation in annual ${ }^{137} \mathrm{Cs}$ deposition since measurements were begun in 1970. The deposition appears to most closely relate to atmospheric testing through 1980. After that time deposition setles to a low value until a small increase is measured during the Chernobyl accident in 1986. The 1987 atmospheric release of ${ }^{137} \mathrm{Cs}$ from SRS is also reflected in a small increase in the annual average deposition.

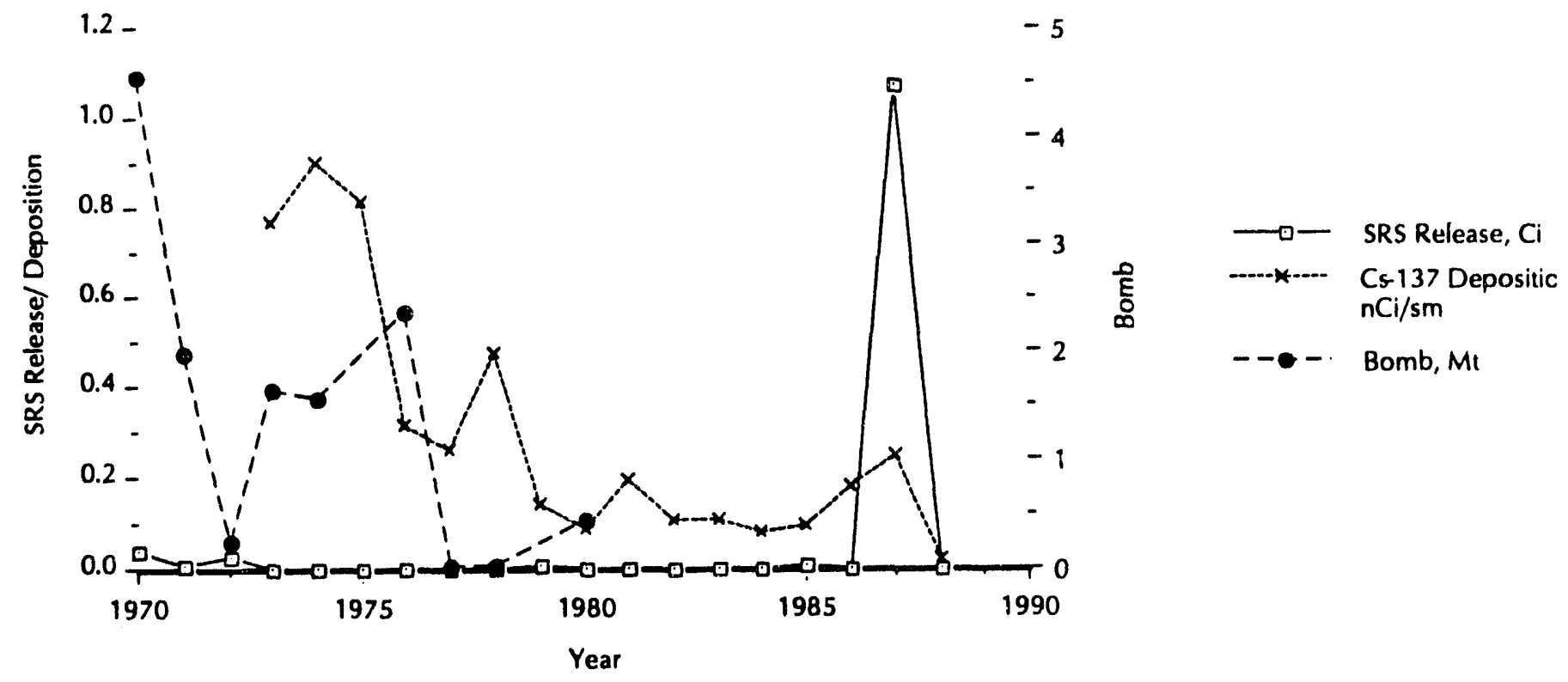

Figure 4-6. ${ }^{27} \mathrm{Cs}$ Deposited in Rainfall Compared to Nuclear Bomb Yields, SRS Releases and Releases from the Chernobyl Accident 


\section{Surface Water Transport}

\section{Surface Waters on the Savannah River Site}

Virtually all SRS radiocesium transported by surface waters originated from aqueous releases from SRS facilities. Several streams have received cooling water from reactors and process water from separations facilities. A small fraction of the radiocesium was transported directly to the Savannah River while most was deposited in stream beds, flood plains, or ponds and slowly released offsite. Prior to the 1964 test ban treaty, fallout from nuclear weapons testing was a major contributor to aqueous cesium throughout the Savannah River watershed.

\section{Lower Three Runs Creek}

Lower Three Runs Creek has the second largest drainage area of streams on the SRS. Both $P$ and $R$ Reactors have discharged effluents to the Lower Three Runs system. On the main SRS site, a large impoundment, Par Pond (2600 acres), was constructed in 1958 to provide recirculating cooling water through $\mathbf{P}$ and $\mathbf{R}$ Reactors. Several smaller ponds were built between the reactors and Par Pond to provide additional cooling for reactor cooling water before it entered Par Pond. The average natural flow rate of Lower Three Runs Creek at the Par Pond dam is $1 \mathrm{~m}^{3} / \mathrm{sec}$. From the Par Pond dam, the creek flows 38 kilometers to the Savannah River.

On March 14, 1991, a ten-square-foot depression was discovered on the lower downstream slope of Par Pond dam. During the next six months, the water level of Par Pond was lowered about 19 feet to reduce the impact of a potential dam failure while assessing the condition of the dam and determining if repairs were necessary. Several studies were initiated by Savannah River Ecology Laboratory (SREL), Savannah River Laboratory (SRL), and the Environmental Monitoring Section, 10 assess the levels of radiocesium in the water and sediment of Par Pond and in the sediment of the Lower Three Runs Creek system.

It is estimated that about 222, curies of radioactive cesium (134 Cs and ${ }^{137} \mathrm{Cs}$ ) was released to the Lower Three Runs Creek system from R Reactor between 1954 and 1964. These releases were associated with leaking fuel and target slugs in the reactor disassembly basin. Water was released from the basin to the Lower Three Runs Creek system to maintain water clarity for moving and working with spent fuel and targets stored underwater. Releases did not exceed the Atomic Energy Commission (AEC) concentration guide in effect at that time. When $R$ Reactor was shut down in 1964, all releases from this source stopped (Hayes, $1991 \mathrm{a}$ ).

Cesium releases from $\mathbf{R}$ Reactor followed two paths to Lower Three Runs Creek. Before September 1961, releases of 71 curies of cesium were via Joyce Branch (now the middle arm or hot arm of Par Pond). Beginning in September 1961, releases of 151 curies were via a cooling water canal and Ponds $A$ and $B$ to the north arm of Par Pond. The amount remaining after decay to 1991 is 112 curies. After correcting for transport to the Savannah River and almost complete decay of the short-lived ${ }^{134} \mathrm{Cs}$ component (half-life $=2.07$ years), an estimated 83 curies of ${ }^{137} \mathrm{Cs}$ remain in the sediments of $R$ Reactor Canal, Ponds $A$ and $B$, Par Pond (includes Pond C) and the Lower Three Runs Creek System (Marter and Boni, 1991). Based on an inventory of about 12 curies of ${ }^{137} \mathrm{Cs}$ in Pond $\mathrm{B}$ (Whicker et al., 1990), an estimated 71 curies remains in Par Pond, Pond C, and the Lower Three Runs Creek system.

Two recent inventories of ${ }^{137} \mathrm{Cs}$ in Par Pond sediments were in close agreement. A survey of pond sediments with an underwater HPGe detector yielded an estimate of $\mathbf{4 2 . 8}$ curies for the entire pond with 9.2 curies exposed following the 19-ft drawdown of the pond. Measurements were made at 18 locations in the pond at depths to 58 feet, the deepest point in the pond. Count rates were obtained from the HPGe spectra for the $662 \mathrm{keV}$ gamma emitted by the ${ }^{137} \mathrm{Cs}$ and its short half-life daughter, ${ }^{137 \mathrm{mBa}}$ (half-life $=2.55$ minutes). HPGe counting efficiencies were adjusted for the depth distribution of ${ }^{17} \mathrm{Cs}$ in sediments as determined from core samples. (Winn, 1991). A survey made by obtaining sediment cores ranging from 16 to $38 \mathrm{~cm}$ in depth and measuring ${ }^{137} \mathrm{Cs}$ content of $1 \mathrm{~cm}$ slices with a Canberra Reverse Electrode Germanium detector yielded an estimate of 44 curies for the entire pond. These measurements showed that most of the ${ }^{137} \mathrm{Cs}$ was at a depth greater than 3 $\mathrm{cm}$ and the maximum concentrations of ${ }^{15} \mathrm{Cs}$ were at a depth of $5-10 \mathrm{~cm}$ below the surface. Essentially, no ${ }^{177} \mathrm{Cs}$ was seen at depths greater than $24 \mathrm{~cm}$ (Marter and Boni, 1991).

Concentrations of ${ }^{17} \mathrm{Cs}$ in Par Pond water have remained above background levels due to the retention of cesium in the sediments of the pond. The distribution of ${ }^{137} \mathrm{Cs}$ with depth in the pond water undergoes seasonal cycling. In the summer, concentrations in bottom water are about $50 \%$ higher than surface water. The cycling coincides with the 
Table 4-1. Inventory of ${ }^{13} \mathrm{Cs}$ in Lower Three Runs (LTR) Creek

Releases to LTR Creek System

$222 \mathrm{Ci}$

Releases decayed to 1991

Activity Remaining in LTR

Pond B

Pond $\mathrm{C}$

Par Pond

LTR Below Par Pond

42.8

25.8

$\overline{83 \mathrm{Ci}}$

annual periods of thermal stratification in the pond. The intense anoxic conditions that develop in the summer are a factor in the cycling. When the thermal stratification disappears in late October or early November, the ${ }^{17} \mathrm{Cs}$ concentrations become nearly uniform throughout the water column. The cesium concentrations in Par Pond are maintained by the ${ }^{15} \mathrm{Cs}$ in the sediments. The current concentration of ${ }^{137} \mathrm{Cs}$ in the pond remains at about $3.5 \mathrm{pCi} / \mathrm{L}$ and is dependent upon the desorption equilibrium coefficient between sediment and water. The amount of ${ }^{137} \mathrm{Cs}$ in the pond water is about 0.22 curies.

Surveys to determine the distribution of ${ }^{137} \mathrm{Cs}$ and other radionuclides in streambed and floodplain sediments of Lower Three Runs Creek below Par Pond were made in $1971,1973,1982$, and 1984, and annual measurements are made at the mouth of the creek. The results of these studies show a wide variation in ${ }^{137} \mathrm{Cs}$ concentrations (i.e., $1 \mathrm{pCi} / \mathrm{g}$ to a few hundred $\mathrm{pCi} / \mathrm{g}$ ), reflecting differences in sediment type and deposition patterns. In most of the sediment cores, the highest ${ }^{137} \mathrm{Cs}$ concentrations occurred in the upper 3 inches. In a few sediment cores, the highest concentrations occurred below the uppermost sediments, reflecting varying flow/deposition regimes in the creek system.

Assuming that the ${ }^{17} \mathrm{Cs}$ distribution associated with exposed sediments in Pond $C$ is similar to that of Par Pond, and knowing that the area of Pond $C$ is 5.7\% of Par Pond proper, it is estimated that Pond C sediments contain 2.4 curies, making the inventory in the Pond C-Par Pond system 45.2 curies $(42.8+2.4=45.2$ curies). The inventory in Lower Three Runs Creek below Par Pond is estimated to be 25.8 curies by subtracting 45.2 curies from the total inventory of 71 curies (Hayes, 1991b). Table 4-1 summarizes the inventory of ${ }^{13} \mathrm{Cs}$ in Lower Three Runs Creek.

\section{Upper Three Runs Creek}

Upper Three Runs Creek is the largest creek on site with a watershed of $540 \mathrm{~km}^{2}$, a natural flow rate of $7 \mathrm{~m}^{3} / \mathrm{sec}$, and a length of $\mathbf{4 0} \mathrm{km}$. Effluents are received from $M$ Area and SRL and, since 1988, the Effluent Treatment Facility in H Area has been releasing treated water. There have been no significant releases of ${ }^{137} \mathrm{Cs}$ to Upper Three Runs Creek.

\section{Steel Creek}

Steel Creek is $18 \mathrm{~km}$ in length and has a watershed of 90 $\mathrm{km}^{2}$. The natural flow rate is $1 \mathrm{~m}^{3} / \mathrm{sec}$, but was as high as 22 $\mathrm{m}^{3} / \mathrm{sec}$ when both $\mathrm{P}$ and $\mathrm{L}$ Reactors discharged cooling water to Steel Creek in the early 1960s. P Reactor cooling water was diverted to Par Pond in 1964 and L Reactor was shut down in 1968, then restarted in 1985. P Reactor disassembly basin water continued to flow to Steel Creek. L Lake was built in 1985 to provide cooling for L Reactor discharges. Steel Creek travels about $3 \mathrm{~km}$ through the Savannah River swamp before entering the Savannah River (Murphy, 1991).

From 1955 to 1973 , approximately $284 \mathrm{Ci}$ of ${ }^{137} \mathrm{Cs}$ was released to Steel Creek (Mackey, 1982). From 1974 to 1989. less than one additional curie was released (Cummins, 1991). Since ${ }^{137} \mathrm{Cs}$ has a strong affinity for sediments, the majority of the released ${ }^{137} \mathrm{Cs}$ was absorbed and/or deposited in the sediments of the Steel Creek system prior to reaching the Savannah River. The inventory was determined in 1985 and indicated $76 \mathrm{Ci}$ from P Area to the SRS boundary. Approximately $9 \mathrm{Ci}$ was located upstream from $\mathrm{L}$ Reactor, $35 \mathrm{Ci}$ between $\mathrm{L}$ Reactor and the Steel Creek delta, $23 \mathrm{Ci}$ in the delta and $9 \mathrm{Ci}$ from the delta to the SRS boundary (Hayes, 1985). Table 4-2 lists this inventory corrected for decay to 1991 . The inventory of ${ }^{137} \mathrm{Cs}$ in the biotic community has been determined to be about $0.4 \mathrm{Ci}$ and the animal community inventory is insignificant due to the much lower biomass (DOE, 1984).

Isotope ${ }^{17} \mathrm{Cs}$ transported down Steel Creek resulted in the deposition of radioactivity in Creek Plantation swamp, an area adjacent to the Savannah River but off SRS. The contamination occurred during periods of river flooding when Steel Creek flowed parallel to the Savannah River for about $6 \mathrm{~km}$ through a swampy area. The slow movement of the water through the swamp allowed the ${ }^{137} \mathrm{Cs}$ bearing

Table 4-2. Inventory of ${ }^{17} \mathrm{Cs}$ in Steel Creek, Decay Corrected to 1991

$\begin{array}{lr}\text { Upstream from L Reactor } & 8 \mathrm{Ci} \\ \text { Between L Reactor and Delta } & 30 \mathrm{Ci} \\ \text { Delita } & 20 \mathrm{Ci} \\ \text { Delta to SRS Boundary } & 8 \mathrm{Ci} \\ \text { Total } & 66 \mathrm{Ci}\end{array}$


sediment to setule out before reaching the river. The swamp flow eventually reentered the Savannah River at Litule Hell Landing. It was estimated in 1974 that approximately $25 \mathrm{Ci}$ of ${ }^{13} \mathrm{Cs}$ was located in Creek Plantation swamp (Marter, 1974), which would have decayed to 17 Ci by 1991 .

\section{Four Mile Creek}

Four Mile Creek has a watershed of $57 \mathrm{~km}^{2}$, is approximately $24 \mathrm{~km}$ long, and has a natural flow of $0.14 \mathrm{~m}^{3} / \mathrm{sec}$. It receives effluent from $F$ and $H$ Areas seepage basins, the Solid Waste Disposal Facility, and, until 1985, cooling water from C Reactor. It has received about $77 \mathrm{Ci}$ of ${ }^{17} \mathrm{Cs}$ and had an estimated inventory of $40 \mathrm{Ci}$ in 1985 (Gladden, 1985). In comparison with Lower Three Runs Creek and Steel Creek, very little work has been done to characterize the inventory of radioactive material. The 1985 estimate can be decay corrected to $35 \mathrm{Ci}$ as of 1991.

\section{Pen Branch}

Pen Branch has a watershed of $55 \mathrm{~km}^{2}$, is approximately 24 $\mathrm{km}$ long and has a natural flow of $0.2 \mathrm{~m}^{3} / \mathrm{sec}$. Once it reaches the Savannah River swamp, the flow path becomes relatively undefined as it flows through the swamp parallel to the Savannah River for about $8 \mathrm{~km}$ before entering Steel Creek. Pen Branch receives cooling water from $K$ Reactor and has received $24 \mathrm{Ci}$ of ${ }^{137} \mathrm{Cs}$. The estimated 1985 inventory of $11.4 \mathrm{Ci}$ (Gladden, 1985) can be decaycorrected to $10 \mathrm{Ci}$ as of 1991 .

\section{Site Stream Summary}

Table 4-3 shows the ${ }^{137} \mathrm{Cs}$ inventory in SRS streams to be $211 \mathrm{Ci}$, decay corrected to 1991 . Total ${ }^{13} \mathrm{Cs}$ releases to
Table 43. Estimaled ${ }^{17} \mathrm{Cs}$ Inventory in SRS Streams (1991) and Creek Plantation
Lower Three Runs Creek Upper Three Runs Creek Steel Creek Creek Plantation Swamp Four Mile Creek Pen Branch
$83 \mathrm{Ci}$ 0 $66 \mathrm{Ci}$ $17 \mathrm{Ci}$ $35 \mathrm{Ci}$ $10 \mathrm{Ci}$

$211 \mathrm{Ci}$ streams (Cummins, 1991), decay corrected to 1991, is 324.6 Ci. Thus, $65 \%$ of the ${ }^{17} \mathrm{Cs}$ released to streams is still on SRS property or in Creek Plantation swamp. The other $35 \%$ has entered the Savannah River.

\section{Savannah River}

The Savannah River forms most of the border between Georgia and South Carolina and drains approximately $25,900 \mathrm{~km}^{2}$ in eastem Georgia and westem South Carolina. The flow rate averages about $285 \mathrm{~m}^{3} / \mathrm{sec}$ at Augusta and increases to $340 \mathrm{~m}^{3} / \mathrm{sec}$ downriver near Clyo, Georgia. During most years of SRS operation, river water measurements were made just upriver from SRS and downriver at Highway 301. Water from the Savannah River is used at two water treatment plants, Beaufort-Jasper and Pon Wentworth. 


\section{Groundwater Concentrations and Transport}

Although both ${ }^{134} \mathrm{Cs}$ and ${ }^{137} \mathrm{Cs}$ have been identified on the site, there is no indication that these uranium fission products have been transported offsite via groundwater migration. The radioisotopes of cesium have entered the SRS groundwater as a result of past operations at SRS, primarily the land disposal of waste water into seepage basins. Cesium radioisotopes have also entered the groundwater at reactor containment basins as a result of abnormal operating conditions at the reactors (Reichen, 1962).

\section{SRS Groundwater System}

The Savannah River Site lies on the Atlantic Coastal Plain about 20 miles southeast of the edge of the Piedmont Physiographic Province. The Coastal Plain is underlain by a seaward dipping wedge of sediments that thins and overlaps the crystalline rocks of the Piedmont (Figure 4-7). Early investigations of the hydrogeology at the site (Siple, 1967) established three geologic and hydrogeologic systems on the site: (1) crystalline basement rocks composed of metamorphic and intrusive igneous rocks; (2) well-indurated Triassic-aged sediments in the Dunbarton Basin; and (3) the overlapping, weakly consolidated Cretaceous to Recent coastal plain sediments.

The crystalline basement rocks have very low permeabilities. Water is stored primarily in the fractures and joints in the rocks. The permeability of the Triassic rocks is also likely to be relative low. Two test wells drilled into the Triassic rocks showed that the water in these rocks is geopressured and that the hydraulic head of the water is above land surface. The origin of the overpressuring is uncertain but has been ascribed to osmotic pressure across the overlying impermeable confining units (Marine, 1974).

Both the crystalline basement rocks and the Triassic rocks are overlain by varying thicknesses of weathering residue containing degraded minerals and clay. Overlying these old soils is a depositional blanket of indurated, poorly-sorted clayey sediments of the Cape Fear Formation (Bledsoe, 1988). This unit and the residual soils hydraulically separate and isolate the younger, sedimentary materials from the Triassic sediments and the crystalline basement rocks.

The third hydrogeologic system is the Cretaceous and younger sedimentary rocks of the Coastal Plain sediments.

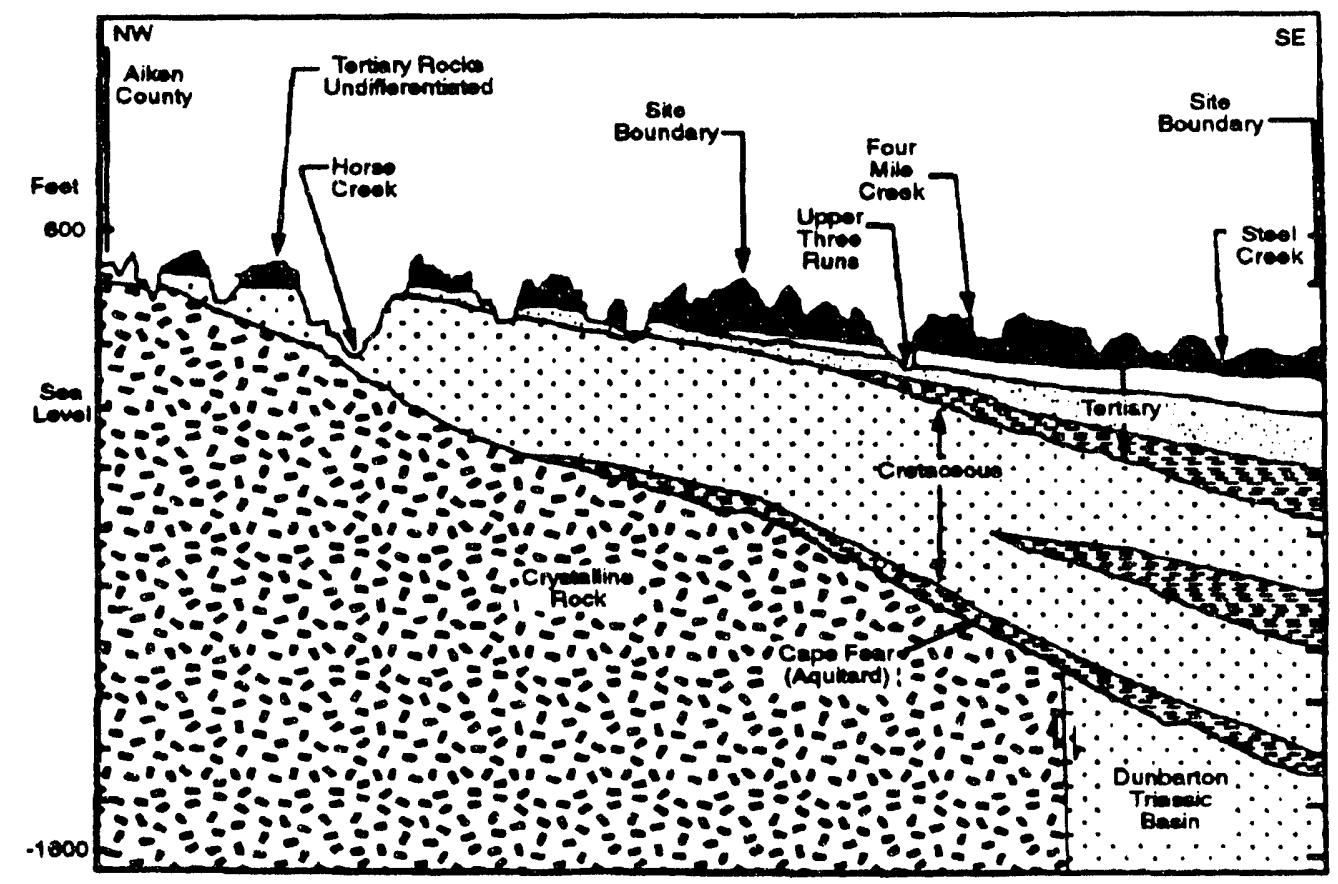

Figure 4-7. Geologial Cross-Section Showing the Main Aquifiers 

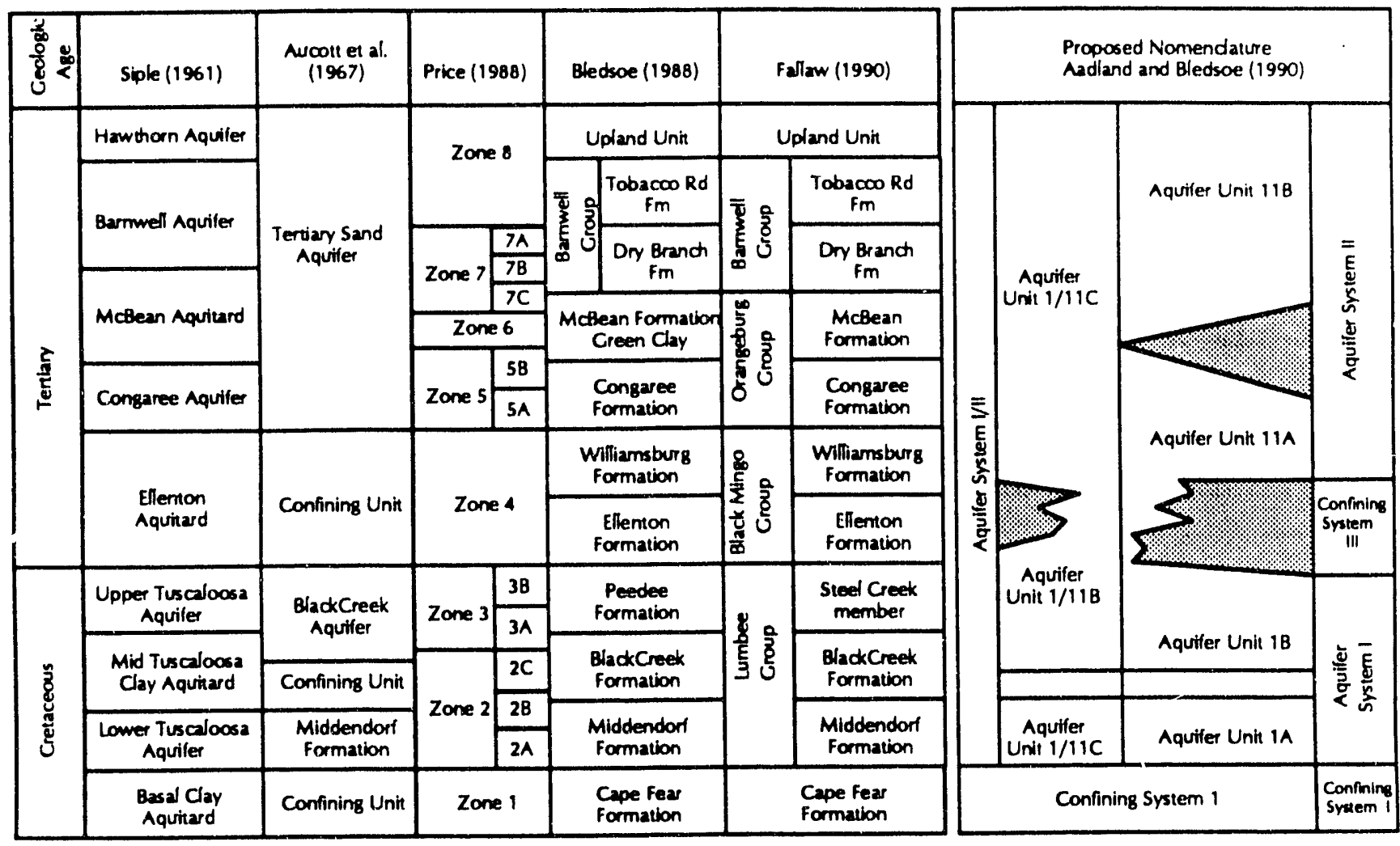

Figure 4-8. Stratigraphic and Hydrostratographic Nomenclature Used on the Savannah River Site

The sediments were largely deposited in shallow marine and fluvial environments (Gohn, 1988). The thickness of the sedimentary units increases woward the southeast across the site. At the northwest boundary, the sedimentary section is about 700 -feet thick and about 1400 -feet thick at the southeastem boundary. As more detailed information has become available, the stratigraphic names applied to the various units have been modified based on the predilections of successive investigators. The principal aquifers on the site have frequently been named after the principal formations, for example, the Barnwell Formation and the Barnwell Aquifer. As stratigraphic names have changed, the names of the aquifers have also been changed as a result.

Figure 4-8 compares some of the changes that occurred in the hydrostratigraphic nomenclature since the mid 1960 s. The currently recommended nomenclature (Aadland and Bledsoe, 1990) takes into account the progressive thickening of the aquifers across the site and the effectiveness of the confining units that separate the aquifer units. The proposed changes avoid tying the aquifer nomenclature to the stratigraphic names. A map view, Figure 4-9, shows the approximate limits of the coastal plain aquifer systems.

At the base of the Coastal Plain sediments is an aquitard composed of residual soils of the basement rocks and dense clays of the Cape Fear Formation. Overlying this confining unit are two aquifers in Cretaceous sands (Aquifer IA and IB). These sands are generally considered to be prolific water producers and are generally the source of water for water supply well: on the site. They are separated from each other by the relatively less permeable beds that make up the Biack Creek Formation.

The Tertiary aquifers are separated from the underlying Cretaccous aquifer units by confining beds of the Black Mingo Group, especially the Ellenton Formation. On the northwestern comer of site, the separation is not as effective as in the southern portion.

In the southeastern area, the Tertiary section can be divided into two separate aquifers, Aquifer Unit IIA (formerly 


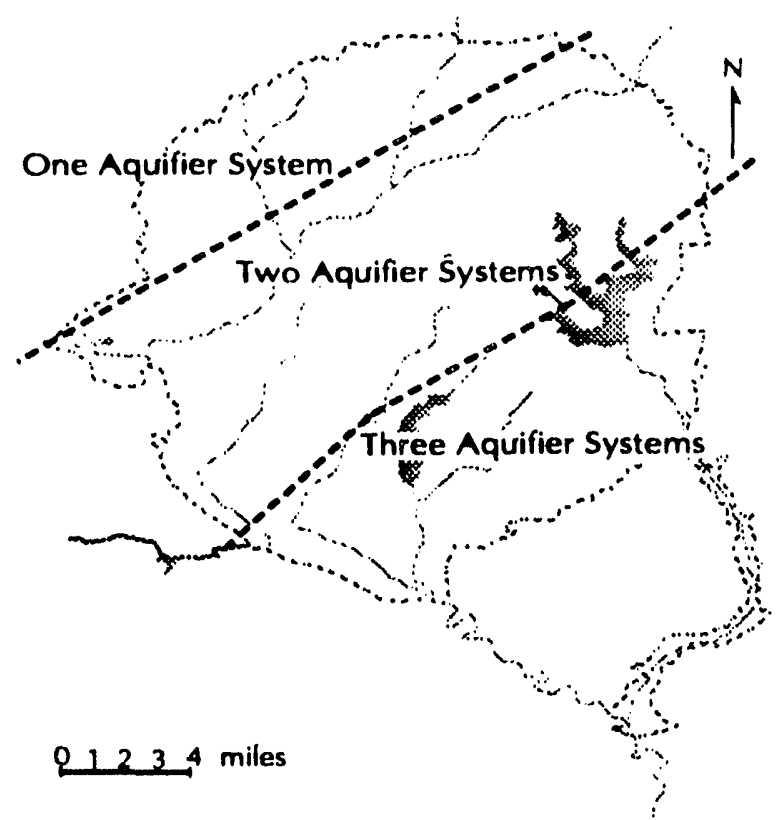

Flgure 4-9. Updip Limits of the Confining Systems in the Coastal Plain Sediments

called the "Congaree Aquifer") and Aquifer Unit IIB (frequently referred to as the "Barnwell Aquifer" or "Watertable Aquifer"). The aquitard or confining beds that separate these two units is a glauconitic clayey zone of the McBean Formation that is locally referred to as the "green clay." This clay pinches out and becomes more sandy toward the Northwest.

In some areas of the site, it is necessary to modify the hydrostratigraphic nomenclature due to local changes in lithologies and topography. For example, in some portions of the site, an aquitard unit referred to as "tan clay" subdivides the uppermost aquifer into two separate zones. In the southem portion of the site, the "tan clay" unit is thin or sporadic and does not form a consistent aquitard.

The level of the water table is controlled primarily by local topographic feaures. The surface of the Atlantic Coastal Plain at the site is a relatively flat plateau (the Aiken Plateau) that has been dissected by stream erosion. The incision of the streams has left relatively isolated, flat-lying surfaces separated by $90-125$ feet deep stream valleys. The depth to the water table below land surface varies from 0 feet, when it outcrops in the stream valleys or wetlands, to a depth of 125 feet below the remnant plateau areas. The depth of the water table is usually controlled by the elevation of the nearest tributary stream of the Savannah River. At many localities onsite, the water table is situated in Tertiary sediments of low water-producing capabilities and perched water tables exist sporadically across the site.

The direction of groundwater flow at any locality may change or even reverse at successively deeper aquifers (Christensen and Gordon, 1983). The aquifers in the Tertiary sediments receive local recharge and flow is generally toward nearby stream valleys. In general, flow at the water table is toward minor tributaries and deeper Tertiary aquifers flow toward major tributaries of the Savannah River. The deepest aquifers at SRS, Aquifer System I, receive recharge in the outcrop areas of the Cretaceous sediments to the north of the site. Groundwater flow beneath the site in System I is toward the Savannah River.

Over much of the site, the potentiometric surface, or hydraulic "head" of the deeper aquifers in the Cretaceous sediments is higher than that of the overlying Tertiary aquifer (Christensen and Gordon, 1983). This upward gradient is an important characteristic of many of the waste disposal areas and has provided protection to the deeper aquifers on the site from downward transport of contaminants. Figure 4-10 outlines the areas where there is an upward hydraulic gradient across the confining units near the Cretaceous-Tertiary boundary.

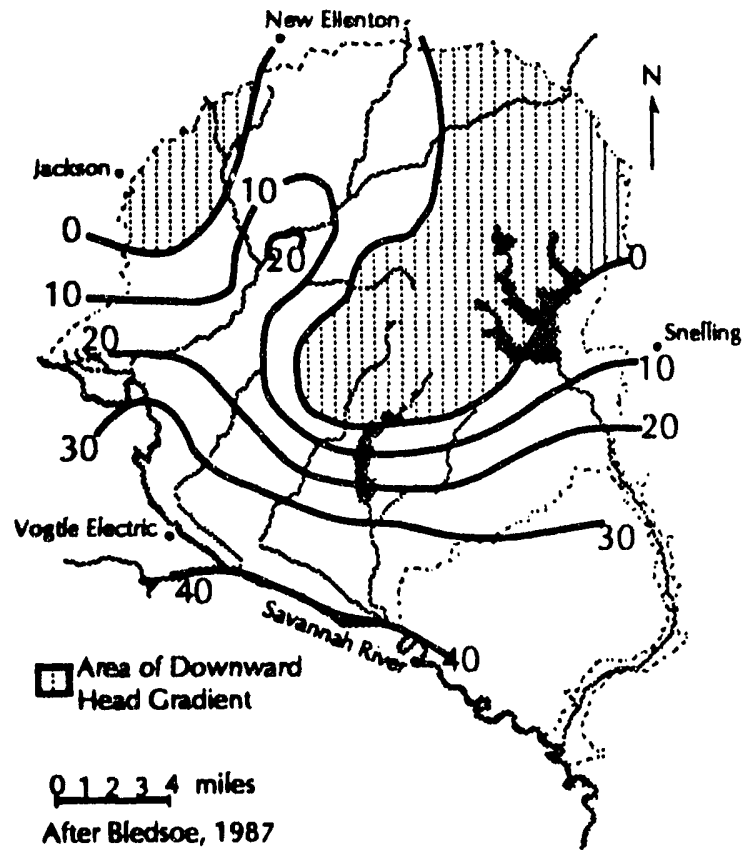

Figure 4-10. Hydraulic Head Differences f.cross Confining Units Near the Cretaceous/Tertiary Boundary 


\section{Geochemistry of Cesium}

The only naturally occurring isotope of cesium, ${ }^{133} \mathrm{Cs}$, is found only in trace amounts in either soils or water. For example, the average crustal abundance is in the range of from 4 to 10 parts per million (Gaines, 1972), and sea water concentrations are reported as low as less than 1 part per billion (Hem, 1970).

Due to its low abundance, cesium forms only a few rare minerals such as pollucite ( $\left.\mathrm{H}_{4} \mathrm{Cs}_{4} \mathrm{Al}_{4} \mathrm{Si}_{3} \mathrm{O}_{3}\right)$ or Avogadriate $\left[(\mathrm{K}, \mathrm{Cs}) \mathrm{BF}_{4}\right]$. The more frequent occurrence of cesium is substituting for potassium in phyllosilicate and tectosilicate minerals such as clays and feldspars. Since cesium and potassium both have the same valence and similar radii, they can both occupy the same structural sites. In fact, much of what is known or inferred of the geochemi try of cesium is based on its many similarities to potassium. In solution both occur as simple monovalent cations and there is litule tendency for either to form complexes with other ions in solution.

In clay-rich environments, such as soils and the Coastal Plain sediments, potassium and cesium are both sorbed from solution an' retained by the clay structure. For most clays, cesium is the more strongly sorbed ion and may displace either potassium from structural sites or divalent ions such as calcium from cation exchange sites. Clay minerals such as illite and vermiculite will retain cesium as a nonexchangeable ion once it has been sorbed from solution (Grim, 1968). This "fixation" of cesium by clays common to Coastal Plain soils limits the migration of cesium radioisotopes via groundwater in most instances.

An assessment of the general ability of the soils on the SRS to retain cesium and other waste water constituents was conducted by Looney et al. (1985). The results of their work indicated that cesium should be highly retained under reasonable conditions of $\mathrm{pH}$, oxidation potentials, and dissolved solids. In some instances, it has been reported that the mobility of groundwater constituents can be enhanced by sequestering by dispersed colloidal materials or ligands being transported by groundwater. This phenomenon, termed "facilitated transport" is becoming more generally recognized at waste disposal sites. The phenomenon itself, the chemical reactions involved, and the transport of colloids or macromolecules in groundwater are not well understood. The potential for facilitated transport of radioisotopes beyond the immediate area of the wastes must be evaluated on a case-by-case basis.

\section{Isotopes ${ }^{134} \mathrm{Cs}$ and ${ }^{137} \mathrm{Cs}$ in SRS Groundwater}

Groundwater monitoring on the Savannah River Site is carried out through a system of wells that have been installed around each of the facilities and especially around each of the waste disposal areas or seepage basins. The majority of these wells are sampled on a quarterly basis and the results reported in the Annual Savannah River Site Environmental Reports (Davis, 1989). Quarterly reports are issued to update the information. Though nonvolatile beta is routinely determined, specific data on ${ }^{134} \mathrm{Cs}$ and ${ }^{137} \mathrm{Cs}$ are usually not available. Most of what we know or infer concerning cesium mobility is based on a relatively small number of site specific studies.

\section{Solid Waste Disposal Facility}

At the Savannah River Site, solid radioactive waste is stored at a single, centrally located Solid Waste Disposal Facility between the $F$ and $\mathrm{H}$ separations areas (Figure 4-11). The original 76-acre burial site is designated as 643-G (old Solid Waste Disposal Facility) and operated between 1953 and 1972. A second area, a 119-acre site, designated 643-7G (new Solid Waste Disposal Facility), was then opened to receive radioactive solid wastes.

The new Solid Waste Disposal Facility is located on a water table divide. The groundwater beneath about half of the 643-7G area and the groundwater beneath the old Solid Waste Disposal Facility flows southward toward Four Mile Creek. The northem half of the 643-7G Solid Waste Disposal Facility flows towards Upper Three Runs. There are few direct measurements of radioisotopes of cesium in groundwater at the Solid Waste Disposal Facility. Generally the nonvolatile beta measurements are low, indicating that the cesium radioisotopes present are also in low activity.

\section{General Separations Area Seepage Basins}

From 1954 to 1988, seepage basins were used on the Savannah River Site for the disposal of waste water that contained low concentration levels of chemicals and radionuclides. Several of these basins were in the General Separations area near the F-Area and $\mathrm{H}$-Area facilities (see Figure 4-11 on page 4-11). The first seepage basin onsite was constructed in 1954 just north of $F$ Area, however, the seepage rate was inadequate to handle the increasing 


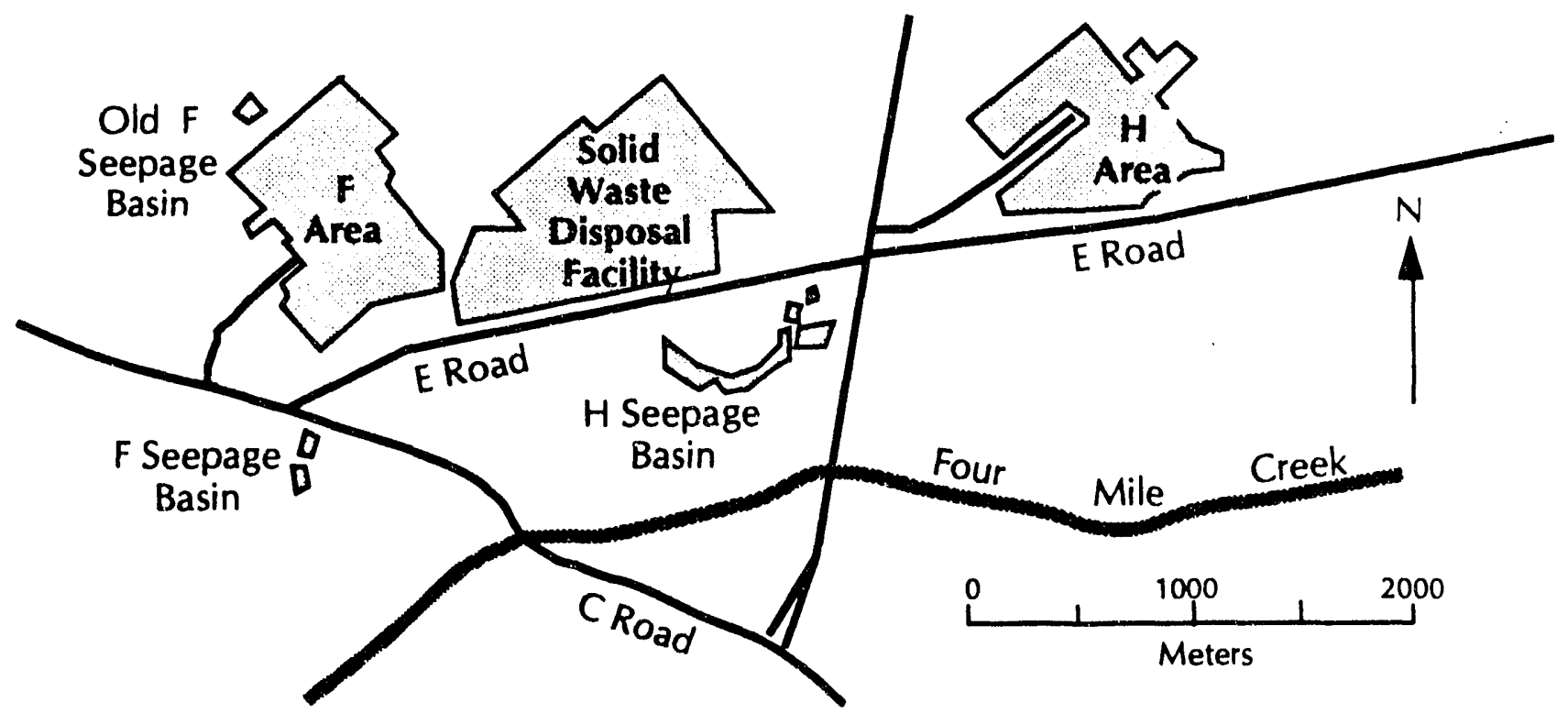

Figure 4-11. Location Map of Waste Disposal Sites in the General Separations Area

volume of wastewater coming from the F-Area facilities. Three additional basins were constructed south of F Area and received effluent from 1954 to 1988.

Water infiltrating from the F-Area seepage basins encounters a perched water table 15-25 feet below the surface and then a normal water table at a depth of $60-65$ feet below the land surface. Flow of water at the water table aquifer is toward Four Mile Creek at a rate estimated to be about 0.5 feet/day (Stone and Christensen, 1983). The water infiltrating from these basins produces a plume that can be identified in monitor wells by its high conductivity and tritium values. In some of the wells, elevated levels of nonvolatile beta are also found (Gordon et al., 1987). Low concentrations of ${ }^{137} \mathrm{Cs}$ were routinely discharged to this basin, totaling about $220 \mathrm{Ci}$ (Cummins et al., 1991). However, ${ }^{13} \mathrm{Cs}$ contributes only a small fraction of the total nonvolatile beta observed in the monitor wells. Some soil analytical results show that ${ }^{17} \mathrm{Cs}$ is adsorted from the infiltrating waters and retained by shallow sediments below the basins (Gordon et al., 1987).

\section{The H-Area Seepage Basins}

Though in close proximity to the F-Area basins, the hydrogeology at the H-Area basins is distinct. The depth of the water table beneath the $\mathrm{H}$-Area basins is only about 20 feeh and the basins are located closer to the groundwater discharge zone along Four Mile Creek. Much of the groundwater flow in this area of the site appears to occur in narrow, high permeability channels in the sediments. While a small percentage of the seepage basin waters penetrates into a deeper aquifer within System II, the majority migrate to an outcrop of the water table, or "seepline" above Four Mile Creek.

An investigation of water chemistry along this seepline by Haselow et al. (1990) shows elevated levels of ${ }^{134} \mathrm{Cs}$ and ${ }^{27} \mathrm{Cs}$ in the effluent. While the values recorded are well below primary drinking water standards $(<0.08$ and $<0.2$ $\mathrm{pCi} / \mathrm{ml}$ respectively), the values are high enough to suggest facilitated transpor is taking place at this locality. At the present time, the physiochemical mechanism involved in this transport of cesium radioisotopes is not well documented or understood.

\section{SRL Seepage Basins}

The four Savannah River Laboratory seepage basins are located in the northwestem section of the site about 3200 feet from the nearest site boundary. The first two basins were placed into service in 1954 and augmented with two additional basins in 1958 and 1960, respectively (Christensen and Gordon, 1983). The four basins are connected via overflow channels and while in operation they received low-level wastes from the Savannah River Laboratory.

The water tabie is more than 100 feet below the level of the seepage basins and below the level of the nearby, unnamed dry tributary channel of Tims Branch (Figure 4-12). The 


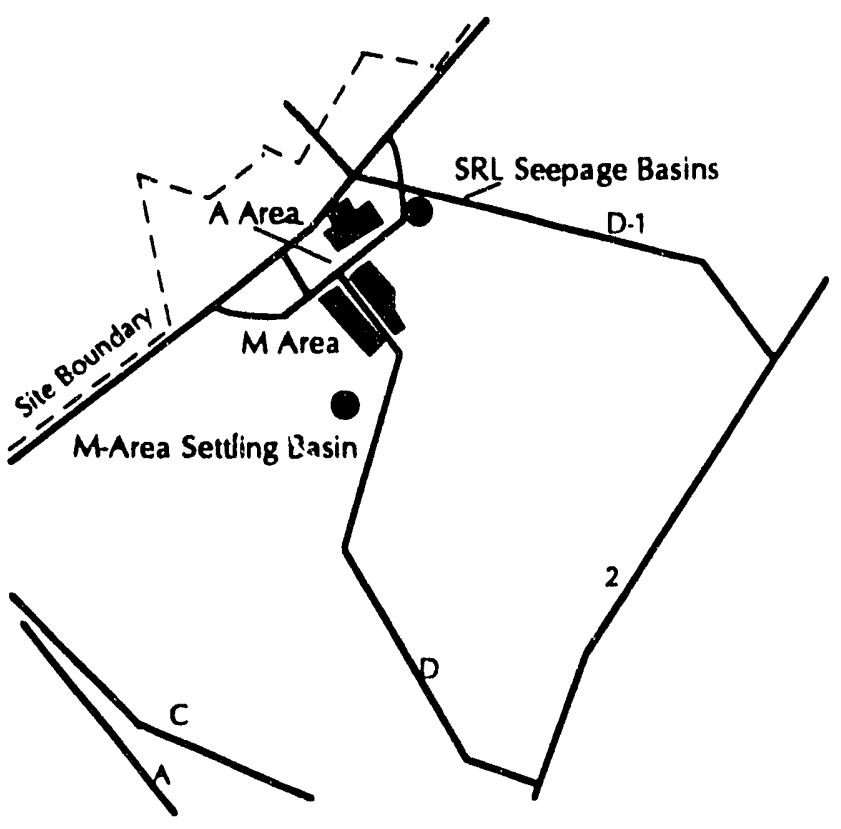

Figure 4-12. Location of the M-Area Setlling Basin and the SRL Seepage Basins

confining beds found in the shallow aquifers elsewhere on the site are either absent or ineffectual in this locality and recharge to the underlying Cretaceous formations is probably occurring in the vicinity of SRL. Although monitor wells installed around the basins have detected evidence of migration of contaminants from the basins, nonvolatile beta is generally low $(<10 \mathrm{pCi} / \mathrm{L})$ and ${ }^{137} \mathrm{Cs}$ is below detection limits in the waters. Shallow cores and grab samples taken from the bottoms of the SRL basins indicates that most of the ${ }^{137} \mathrm{Cs}$ inventory in the basins is retained in the upper few inches of soil beneath the basins (Stone and Christensen, 1983).

\section{CMX/TNX Seepage Basins}

The primary purpose of the TNX area is to run pilot-scale testing of chemical processes and related activities. Several waste disposal sites have been active in the TNX area. Two seepage basins that are no longer used lie near the area boundaries and there exists an old Solid Waste Disposal Facility (Figure 4-13). The old seepage basin operated from 1958 to 1980 . This basin ceased receiving waste water in 1980. In 1981, a breach was opened in the western wall of the basin and the impounded water in the basin was drained into the adjacent wet lands (Christensen and Gordon, 1983). The old basin was then backfilled with a sand and clay mix and capped with clay.

The new TNX seepage basin was opened in 1980 and operated until 1988. Radionuclides are apparently not a concern at either of the TNX seepage basins. The maximum nonvolatile beta reponted was $196 \mathrm{pCi} / \mathrm{L}(0.196 \mathrm{pCi} / \mathrm{ml})$ just down gradient from the old TNX basin. The ${ }^{13} \mathrm{Cs}$ activity is below the detection limit in the few cases where analytical data are available on this location.

\section{Reactor Areas Seepage Basins}

In the five reactor areas on the site, earthen basins were used both as seepage basins and containment basins. The seepage basins received low-level radioactive purge waters from the reactor disassembly buildings. Originally, the purge waters were pumped directly to the basins before the use of sand filters and mixed-bed deionizers were introduced during the 1960 s (Davis et al., 1989). While approximately 20 different types of radionuclides have been sent to these basins, the bulk of radioactivity is ${ }^{3} \mathrm{H},{ }^{90} \mathrm{Sr}$, and ${ }^{137} \mathrm{Cs}$ (Stone and Christensen, 1983).

R-Area basins show by far the highest values. A large proportion of this ${ }^{17} \mathrm{Cs}$ inventory resulted from the failure of an experimental fuel element during a calorimeter test during the fall of 1957 . An estimated $900 \mathrm{Ci}$ of ${ }^{137} \mathrm{Cs}$ was discharged to basin No. 1 as a result of the incident.

The monitoring programs for the reactor area basins collect data on nonvolatile beta in the groundwater but identification of the source radionuclides has not been undertaken to date. Interpretation of the transport of cesium radioisotopes

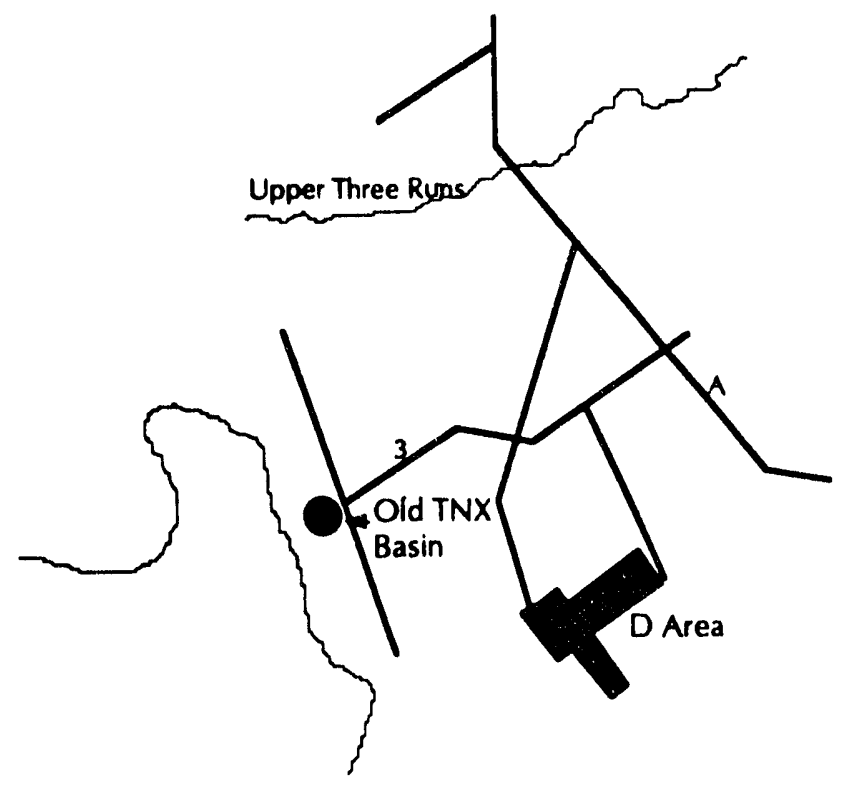

Figure 4-13. Location of the Old TNX Seepage Basins 
from the basins is not feasible based on the existing data and will be deferred until more information is available.

\section{Ford Building Seepage Basin}

The Ford Building in the Central Shops Area of the site is used for the repair of heat exchangers. Small volumes of low-level waste water have been generated an " lischarged to a seepage basin. The total ${ }^{137} \mathrm{Cs}$ discharge inventory to the basin has been estimated to be $2.4 \times 10^{-4} \mathrm{Ci}$. Until 1990 , there were no monitor wells down gradient from this seepage basin and there are no data available at present on the transport of cesium radioisotopes.

\section{General Observations}

Though there is an abundance of information on nonvolatile beta activity in SRS groundwater, the monitoring program does not routinely analyze for cesium radioisotopes. General geochemical theories, laboratory studies, and field investigations suggest that the mobility of the radioactive isotopes of cesium should be limited in the subsurface. In most areas of the site, hydrogeologic conditions also favor the retention of cesium in the soil or in the shallow water table. These conditions include a high percentage of clays with active sorption or exchange sites, generally low to moderate permeabilities in the Tertiary sediments, and upward hydraulic gradients in the Cretaceous aquifers over much of the site. Under some circumstances, such as those at the H-Area seepage basin, cesium transport to the seepline may have been aided by facilitated transport on colloids in the groundwater. 


\section{Cesium in Wildlife}

The Savannah River Site provides a protected area where many species of wildlife thrive. The environmental monitoring program collects and analyzes a thorough representation of wildlife from the Site to help assess any impact SRS operations may have on the wildlife populations. Additionally, animals that are taken offsite for human consumption are monitored to assure compliance with applicable radiation dose limits.

After the Site was closed to the public, the indigenous deer population grew from approximately 100 animals in 1951 to over 1400 animals in 1963. In 1965, managed public hunts were initiated to manage the herd and reduce the number of deer-vehicle collisions. The Savannah River Site is divided into 50 compartments, of which 24 are hunted yearly, 12 are hunted biennially, and 6 are hunted every third year. Eight comparments are not hunted.

Prior to 1969 , approximately $20 \%$ of animals were monitored. Since 1969, all animals have been taken to a field station and monitored for cesium using a portable monitor equipped with a 2-in.-by-2-in. sodium iodide detector. Samples removed from approximately 5-10\% of animals undergo laboratory analysis. Data from field analyses are given in Table 4-4 and Figure 4-14 shows a general downward trend in ${ }^{137} \mathrm{Cs}$ levels in deer. It should be noted that no attempt has been made to correlate cesium levels with hunt compartment. Access to site effluent streams in

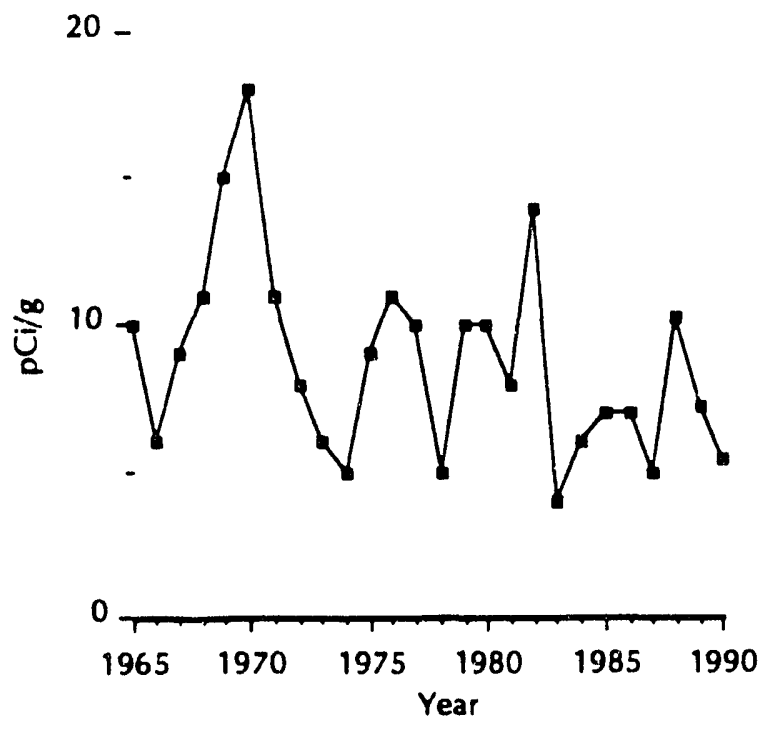

Figure 4-14. ${ }^{15} \mathrm{Cs}$ in Deer (pCi/gm) certain compartments could easily explain some of the annual variation observed.

Hogs, which remained after the farms on which they belonged were relocated, have thrived on the Savannah River Site. Because of the danger of hog-vehicle accidents, and the damage to timber stands, hogs are trapped as well as hunted during the fall hunts. Hogs which are trapped (under a contract with the U.S. Forest Service) are disposed of onsite. Hogs taken during the hunts, and taken offsite for consumption, are monitored in the same fashion as deer. The data are given in Table 4-5 and Figure 4-15 and show the same general downward trend as was seen with deer.

Until 1971, deer and hogs were the only animals routinely analyzed specifically for ${ }^{137} \mathrm{Cs}$. Nonvolatile beta activity was the measurement performed on other wildlife samples.

Fur bearing animals such as foxes, raccoons, etc., are trapped along ten trap lines located strategically throughout the Savannah River Site, and a swamp transect near Steel Creek Landing. Trapped animals are seni to the laboratory and analyzed for gamma-emitting radionuclides. Beavers are not routinely analyzed. The data for fur bearing animals are reported in Table 4-6 and Figure 4-16.

Ducks and coots are trapped by the Savannah River Ecology Laboratory and SRS Environmental Monitoring Section

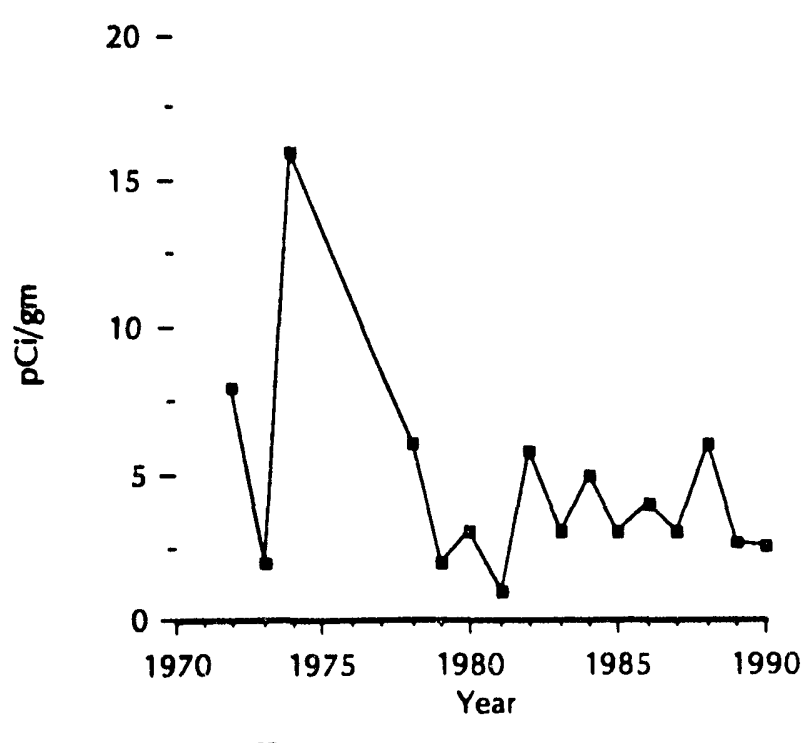

Figure 4-15. $\quad{ }^{137} \mathrm{Cs}$ in Hogs (pCi/gm) 


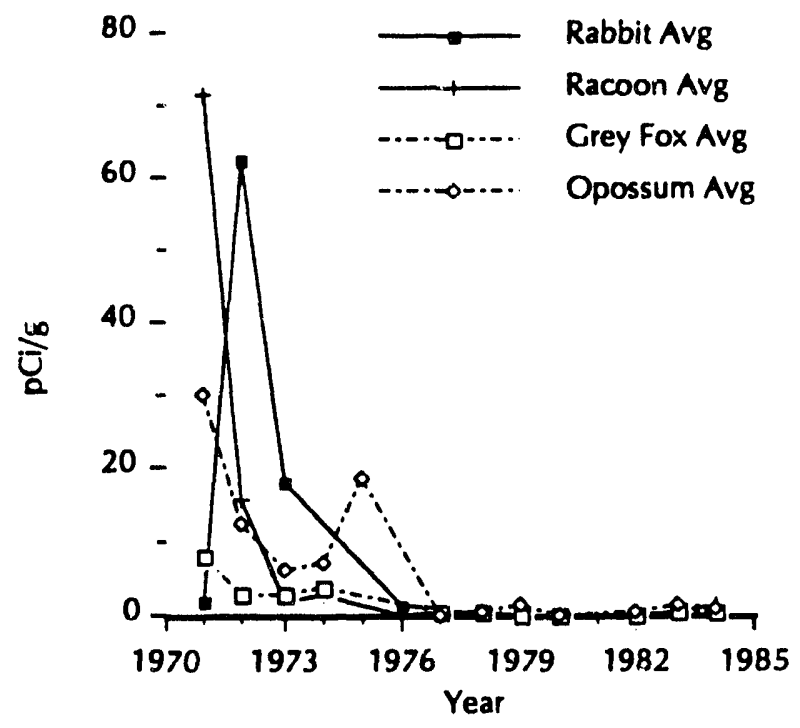

Figure 4-16. $\quad{ }^{137} \mathrm{Cs}$ in Fur Bearers (pCi/gm)

and analyzed for gamma-emitting radionuclides. Turkeys trapped on SRS are used to repopulate South Carolina game areas. Before being removed from the Site, they are monitored with the same instruments used to monitor deer in the field (see Table 4-7 and Figure 4-17).

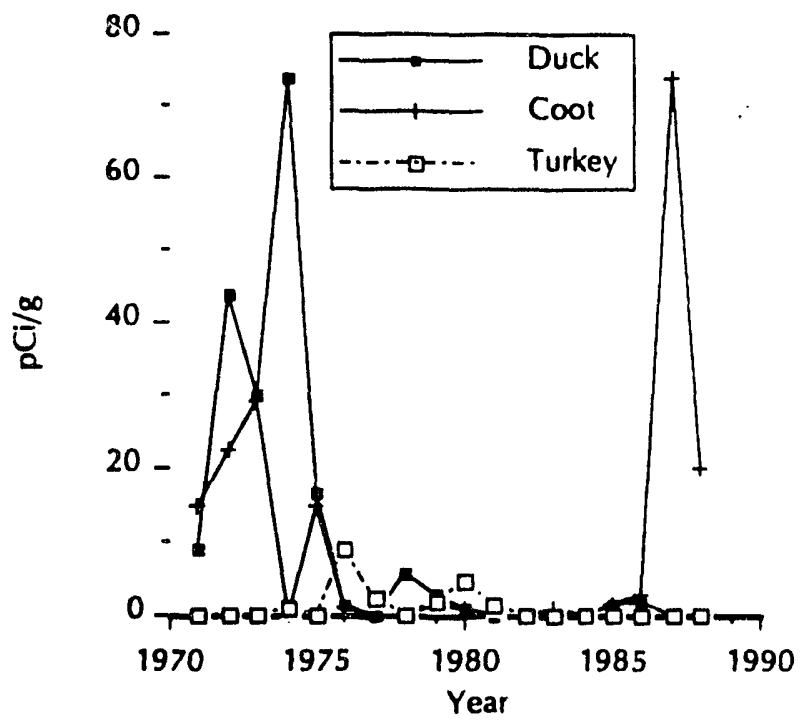

Figure 4-17. ${ }^{137} \mathrm{Cs}$ in Fowl (pCi/gm)

A variety of other animals have been obtained and analyzed over the years (see Table 4-8), but deer, hogs, turkeys, fur bearers, and waterfowl are the only animals for which there are on-going programs. 
Table $4-4 .{ }^{17} \mathrm{Cs}$ in Deer (pCi/g)

$\begin{array}{rrrr}\text { Year } & \text { No. of Deer } & \text { Avg } & \text { Max } \\ 1965 & 198 & 10 & 10 \\ 1966 & 541 & 6 & 24 \\ 1967 & 1032 & 9 & 104 \\ 1968 & 669 & 11 & 74 \\ 1969 & 889 & 15 & 204 \\ 1970 & 864 & 18 & 77 \\ 1971 & 865 & 11 & 48 \\ 1972 & 808 & 8 & 38 \\ 1973 & 1158 & 6 & 31 \\ 1974 & 1551 & 5 & 52 \\ 1975 & 1391 & 9 & 36 \\ 1976 & 1357 & 11 & 41 \\ 1977 & 1271 & 10 & 42 \\ 1978 & 1287 & 5 & 65 \\ 1979 & 1079 & 10 & 98 \\ 1980 & 961 & 10 & 98 \\ 1981 & 1791 & 8 & 47 \\ 1982 & 2063 & 14 & 73 \\ 1983 & 1597 & 4 & 16 \\ 1984 & 1038 & 6 & 23 \\ 1985 & 1022 & 7 & 30 \\ 1986 & 944 & 7 & 29 \\ 1987 & 606 & 5 & 45 \\ 1988 & 855 & 10.2 & 60 \\ 1989 & 710 & 7.3 & 25 \\ 1990 & 1068 & 5.5 & 18 \\ & & & \end{array}$


Tabie 4.5. ${ }^{17} \mathrm{Cs}$ in Hogs (pCi/g)

$\begin{array}{ccrr}\text { Year } & \text { No. of Animals } & \text { Avg } & \text { Max } \\ 1972 & 17 & 8 & 35 \\ 1973 & 12 & 2 & 5 \\ 1974 & 38 & 16 & 75 \\ 1975 & 45 & & \\ 1976 & 177 & & \\ 1977 & 57 & 6 & 23 \\ 1978 & 34 & 2 & 7 \\ 1979 & 61 & 3 & 23 \\ 1980 & 32 & 1 & 10 \\ 1981 & 33 & 5.8 & 51 \\ 1982 & 194 & 3 & 21 \\ 1983 & 133 & 5 & 24 \\ 1984 & 104 & 3 & 11 \\ 1985 & 78 & 4 & 21 \\ 1986 & 127 & 3 & 11 \\ 1987 & 123 & 6.1 & 14 \\ 1988 & 146 & 2.7 & 17 \\ 1989 & 178 & 2.6 & \\ 1990 & 132 & & \end{array}$

Data does not exist or is not readily available for blank spaces in table

Table 4-6. ${ }^{17} \mathrm{Cs}$ in Fur Bearers (pCi/g)

\begin{tabular}{|c|c|c|c|c|c|c|c|c|c|c|}
\hline Year & $\begin{array}{l}\text { Rabbit } \\
\text { Max }\end{array}$ & $\begin{array}{c}\text { Rabbit } \\
\text { Avg }\end{array}$ & $\begin{array}{l}\text { Raccoon } \\
\text { Max }\end{array}$ & $\begin{array}{c}\text { Raccoon } \\
\text { Avg }\end{array}$ & $\begin{array}{c}\text { Grey Fox } \\
\operatorname{Max}\end{array}$ & $\begin{array}{c}\text { Grey Fox } \\
\text { Avg }\end{array}$ & $\begin{array}{l}\text { Oppossum } \\
\text { Max }\end{array}$ & $\begin{array}{l}\text { Oppossum } \\
\text { Avg }\end{array}$ & $\begin{array}{l}\text { Beaver } \\
\text { Max }\end{array}$ & $\begin{array}{l}\text { Beaver } \\
\text { Avg }\end{array}$ \\
\hline 1971 & 8 & 2 & $\begin{array}{r}420 \\
50\end{array}$ & $\begin{array}{l}71.2 \\
750\end{array}$ & 8 & 8 & $\begin{array}{r}230 \\
36\end{array}$ & 30.2 & & \\
\hline 1972 & 500 & 62.4 & 59 & 15.8 & 3 & 3 & 36 & 12.3 & 130 & 82.8 \\
\hline 1973 & 63 & 18 & 3 & 2 & 4 & 3 & 15 & 6 & 110 & 110 \\
\hline $\begin{array}{l}1974 \\
1975\end{array}$ & & & 5 & 3 & 5 & 4 & $\begin{array}{r}26 \\
308\end{array}$ & $\begin{array}{r}7 \\
188\end{array}$ & & \\
\hline 1976 & 3.2 & 1.2 & 0.1 & 0.1 & & & & & & \\
\hline 1977 & 3.2 & 0.8 & 0.9 & 0.5 & 1.2 & 0.5 & 0.3 & 0.2 & & \\
\hline 1978 & 0.1 & 0.05 & 0.6 & 0.4 & 0.4 & 0.3 & 1 & 0.4 & & \\
\hline 1980 & 0.17 & 0.17 & 0.22 & 0.11 & 0.07 & 0.07 & 0.36 & 0.14 & 0.83 & 0.46 \\
\hline 1979 & 0.05 & 0.04 & 0.1 & 0.1 & 0.18 & 0.15 & 5.83 & 1.2 & & \\
\hline 1982 & 0.06 & 0.03 & 0.06 & 0.04 & 0.11 & 0.11 & 0.82 & 0.26 & & \\
\hline 1983 & & & 0.49 & 0.305 & 0.39 & 0.31 & 2.11 & 1.31 & 0.3 & 0.3 \\
\hline 1984 & 0.14 & 0.07 & 6.56 & 1.399 & 0.96 & 0.57 & 3.23 & 1.159 & & \\
\hline $\begin{array}{l}1985 \\
1986\end{array}$ & & & & & 6.1 & & 10 & & 1.6 & 1.08 \\
\hline 1987 & 0.71 & & $\begin{array}{l}10 \\
1.82\end{array}$ & & 2.85 & & 3.25 & & 1.64 & 1.08 \\
\hline 1988 & 1.1 & & 2.5 & & 3.2 & & 6.3 & & 216 & \\
\hline 198 & 0.41 & & 16 & & 1.3 & & 13 & & & \\
\hline
\end{tabular}

Data does not exist or is not readily available for blank spaces in table. 
Table 4-7. ${ }^{17} \mathrm{Cs}$ in Fowl (pCi/g)

\begin{tabular}{|c|c|c|c|c|c|c|}
\hline Year & $\begin{array}{l}\text { Duck } \\
\text { Max }\end{array}$ & $\begin{array}{l}\text { Duck } \\
\text { Avg }\end{array}$ & $\begin{array}{l}\text { Cool } \\
\text { Max }\end{array}$ & $\begin{array}{c}\text { Cool } \\
\text { Avg }\end{array}$ & $\begin{array}{l}\text { Turkey } \\
\text { Max }\end{array}$ & $\begin{array}{r}\text { Turkey } \\
\text { Avg }\end{array}$ \\
\hline $\begin{array}{l}1971 \\
1972 \\
1973\end{array}$ & $\begin{array}{r}12 \\
170 \\
110\end{array}$ & $\begin{array}{r}9 \\
43.6 \\
29.8\end{array}$ & $\begin{array}{r}38 \\
80 \\
100\end{array}$ & $\begin{array}{r}15 \\
22.2 \\
29\end{array}$ & & \\
\hline 1974 & 74 & 74 & & & 1 & 1 \\
\hline 1975 & 81 & 16.9 & & 15 & & \\
\hline 1976 & 8.7 & 1.6 & 2.5 & 0.9 & 11 & 9 \\
\hline 1977 & 0.5 & 0.17 & 0.3 & 0.2 & 4 & 2.3 \\
\hline 1978 & 36.1 & 5.7 & & & & \\
\hline 1980 & 42 & 2.99 & 5.3 & 1.59 & 3 & 1.72 \\
\hline 1979 & 4.96 & 1.04 & 2.25 & 1.1 & 13 & 5 \\
\hline 1981 & 3.22 & & & & 2 & 1.3 \\
\hline 1982 & & & & & & \\
\hline $\begin{array}{l}1983 \\
1984\end{array}$ & 3.54 & 0.705 & 1.96 & 1.05 & & \\
\hline 1985 & 16 & 1.22 & 2.2 & 1.3 & & \\
\hline 1986 & 2.6 & 1.73 & 3.5 & 2.8 & & \\
\hline 1987 & 2.68 & & 114.5 & 73.82 & & \\
\hline 1988 & 43 & & 216 & 19.8 & & \\
\hline
\end{tabular}

Data does not exist or is not readily available for blank spaces in table.

Table 4-8. ${ }^{17} \mathrm{Cs}$ in Miscellaneous Animals (pCi/g)

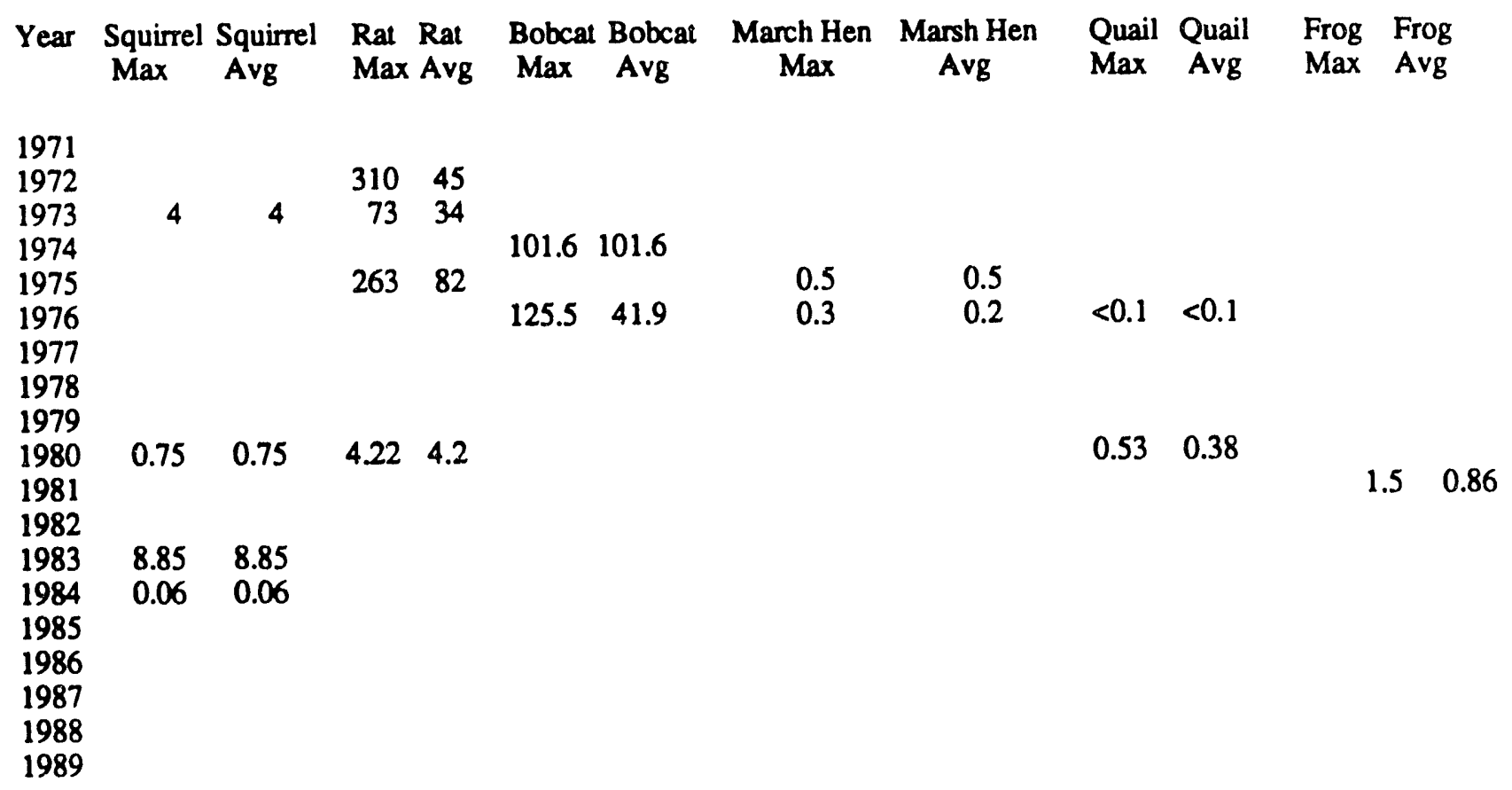

Data does not exist or is not readily available for blank spaces in table. 


\section{References}

Aadland, R. K., and H. W. Bledsoe, 1990, "Classification of Hydrostratigraphic Units at Savannah River Site, South Carolina", WSRC-RP-90-987, Westinghouse Savannah River Company, Aiken, SC.

Aucoth W. R., M. E. Davis, and G. K. Speiran, 1987, "Geohydrologic Framework of the Coastal Plain Aquifers of South Carolina", U.S.G.S. Water-Resources Investigation Report 85-4271.

Bledsce, H. W., 1984, "SRP Baseline Hydrogeologic Investigation - Phase I", DPST-84-833, E.I. du Pont de Nemours and Company, Savannah River Laboratory, Aiken, SC.

Bledsoe, H. W., 1986, "SRP Baseline Hydrogeologic Investigation - Phase II", DPST-86-674, E.I. du Pont de Nemours and Company, Savannah River Laboratory, Aiken, SC.

Bledsoe, H. W., 1988, "SRP Baseline Hydrogeologic Investigation - Phase III", DPST-88-627, E.I. duPont de Nemours \& Co., Savannah River Laboratory, Aiken, SC.

Christensen, E. J., and D. E. Gordon, 1983, "Technical Summary of Groundwater Quality Protection Program at Savannah River Plant, Volume 1", DPST-83-829, E.I. duPont de Nemours \& Co., Savannah River Laboracory, Aiken, SC.

Cummins, C. L., et al., 1991, "Radioactive Releases at the Savannah River Site 1954-1989 (U)", WSRC. RP-91-684, February, 1991.

Davis, H. A., D. K. Martin, and J. L. Todd, 1989, "Savannah River Site Environmental Repont for 1988 (U)", WSRC-RP-89-59-1, Westinghouse Savannah River Co., Savannah River Site, Aiken SC.

DOE, 1984, "Final Environmental Impact Statement, L-Reactor Operation Savannah River Plant", DOE/ EIS-0108, Volume 2, U.S. Department of Energy, May 1984.

Gaines, R. V. 1972, "Cesium; Element and Geochemistry", in Fairbridge, R.W. (ed.), Encyclopedia of Geochemistry and Environmental Sciences", Van Nostrand Reinhold Co., New York, pp 147-148.

Gladden, J. B., et al., 1985, "Comprehensive Cooling Water Study Annual Report", DP-1697-4, July 1985.

Gohn, G.S., 1988, "Late Mesozoic and early Cenozoic Geology of the Atlantic Coastal Plains; North Carolina to Florida", in Sheridan, R.E., and J.A. Grow, (eds.), "The Geology of North America", v.I-2, Boulder, CO., Geol. Soc. Am., pp 107-130.
Gordon, D. E., W. F. Johnson, D. S. Kaback, B. B. Looney, R. L. Nichols, and C. B. Shedrow, 1987, "Characterization Recommendation for Waste Sites at the Savannah River Plant", DPST-87-667, E.I. duPont de Nemours \& Company., Savannah River Laboratory, Aiken, SC.

Grim, R. E., 1968, "Clay Mineralogy” (2nd ed.), McGrawHill Book Co., New York, p 596.

Haselow, J. S., J. S. Harris, B. B Looney, N. V. Halverson, and J. B. Gladden, 1990, “Analysis of Soil and Water at the Four Mile Creek Seepline near the F\&H Areas of SRS (U)", WSRC-RP-90-0591, Westinghouse Savannah River Co., Savannah River Laboratory, Aiken, SC.

Hayes, D. W., 1985, “Cs-137 Concentrations in Steel Creek in 1984", DPST-85-220, Revised, January 28, 1985.

Hem, 1970, "Study and Interpretation of the Chemical Characteristics of Natural Water".

Looney, B. B., M. V. Grant, and C. M. King, 1985, “Estimation of Geochemical Parameters for Assessing Subsurface Transport at the Savannah River Plant", DPST-85-904, E.I. du Pont de Nemours \& Co., Savannah River Laboratory, Aiken, S.C.

Looney, B. B., J. B. Picket, C. M. King, W. G. Holmes, W. F. Johnson, and J. A. Smith, 1986, "Selection of Chemical Constituents and Estimation of Inventories for Environmental Analysis of Savannah River Plant Waste Sites",DPST-86-291, E.I. du Pont de Nemours \& Company, Savannah River Laboratory, Aiken, SC.

Mackey, H. E., Jr., 1982, "Environmental Information Document L-Reactor Reactivation" DPST-81-241, April 1982.

Marine, W. I., 1974, “Geohydrology of Buried Triassic Basin at Savannah River Plant, South Carolina", American Association Petroleum Geologists Bulletin, V. 58, pp 1825-1837.

Marter, W. L., and A. L. Boni, 1991, "Summary of Radiological Impacts of Par Pond Drawdown", SRLETS-910579, Westinghouse Savannah River Company, Aiken, SC.

Marter, W.L., 1974, "Radioactivity from SRP Operations in a Downstream Savannah River Swamp", DP-1370, September 1970.

Murphy, C. E. Jr., et al., 1991, "Tritium in the Savannah River Site Environment", WSRC-RP-90-424-1, Revision 1, May 1991. 
Reichert, S. O., 1962, "Radionuclides in Groundwater at the Savannah River Plant Waste Disposal Facilities", Joumal of Geophysical Research, V. 67, pp 4363-4374.

Siple, G.E., 1967, "Geology and Ground water of the Savannah River Plant and Vicinity, South Carolina", U.S. Geological Survey Water Supply Paper 1841, U.S. Government Printing Office, Washington, D.C.

Stone, J. A., and E. J. Christensen, 1983, "Technical Summary of Groundwater Quality Protection Program at
Savannah River Plant, Volume II - Radioactive Wasten, DPST-83-829, Vol. II, E.I. du Pont de Nemours \& Company, Savannah River Laboratory, Aiken, S.C.

Whicker, et al., Whicker, F. W, J. D. Pinder, J. W. Bowling, J. J. Alberts, and I. L. Brisbin Jr., 1990, "Distribution of Long-Lived Radionuclides in an Abandoned Reactor Cooling Reservoir", Ecological Monogram, 60 , pp 471-496, 1990. 


\section{Chapter 5. \\ Environmental Research on ${ }^{137} \mathrm{Cs}$ by Savannah River Ecology Laboratory}

Early research on the behavior of radionuclides in fallout from nuclear weapons tests indicated that ${ }^{137} \mathrm{Cs}$ was more available for root uptake by plants and incorporation into biota in the Southeast than in other regions of the country (Dahlman et al., 1975; Cummings et al., 1969; Cummings et al., 1971; Jenkins and Fendley, 1971). The greater availability of ${ }^{137} \mathrm{Cs}$ to the biota was mosi prevalent on the Coastal Plain and was apparently related to the prevalence of kaolinite clay in Coastal Plain soils and sediments (Dahlman et al., 1975; Cummings et al., 1969). Multi-lattice clays, such as illite, fix cesium isotopes into unavailable forms (Lomenick and Gardiner, 1965), but kaolinite does not (Dahlman et al., 1975). Thus, ${ }^{137} \mathrm{Cs}$ deposited on Coastal Plain areas was not sequestered in soils and sediments but remained in the biota. Research on ${ }^{177} \mathrm{Cs}$ by SREL has confirmed and extended these early observations. Although SREL research on cesium behavior in the environment has occurred across the SRS site, the most extensive research has occurred in two locations, the flood plain of Steel Creek and the Par Pond - Pond B reservoir system. These systems received cesium isotopes from aqueous discharges from SRS facilities. Discharges from PReactor were the source for cesium isotopes in Steel Creek. Discharges from R Reactor were the source for the Par Pond-Pond B system. 


\section{SREL Research in Steel Creek}

Extensive research on cesium behavior in the flood plain of Steel Creek began in 1971 (Anderson et al., 1973) with data collection persisting into the 1980s (Brisbin et al., 1989; Gladden et al., 1985). The flood plain of Steel Creek is a complex mosaic of habitats. In some areas, the flood plain is usually inundated by 0.15 to $0.5 \mathrm{~m}$ of water and supports a marsh-like community of emergent aquatic plants. These are plants whose roots are in the sediments but whose leaves project above the water surface. Other parts of the flood plain are only slightly or infrequently inundated. These areas support a variety of tree species.

The research had several objectives, including; (1) to document the availability of cesium for plant uptake, and (2) to evaluate the subsequent transfer of cesium through food chains. As research progressed in Steel Creek, it became apparent that there was considerable variation in cesium concentrations in the biota, and data were obtained to examine the variation in cesium concentrations among species as well as spatial variation in cesium concentrations within species.

An important initial finding in Steel Creek was the verification that cesium remained available in the sediments. Brisbin et al. (1974) demonstrated that between 6\% and $12 \%$ of the ${ }^{17} \mathrm{Cs}$ deposited in the sediments could be desorbed by naturally occurring waters of the SRS. Greater amounts of ${ }^{137} \mathrm{Cs}$ could be desorbed by stronger salt solutions. Brisbin et al. (1974) also demonstrated that ${ }^{137} \mathrm{Cs}$ concentrations varied with sediment composition. Finer sediments composed largely of silt and clay particles had greater ${ }^{137} \mathrm{Cs}$ concentrations than coarse sediments composed largely of sand. The ${ }^{17} \mathrm{Cs}$ concentrations for fine sediments averaged $170 \mathrm{pCi} / \mathrm{g}$, whereas the average for coarse sediments was only $18 \mathrm{pCi} / \mathrm{g}$.

\section{Uptake of ${ }^{137} \mathrm{Cs}$ by Plants}

Studies of plants demonstrated that ${ }^{157} \mathrm{Cs}$ was readily available for root uptake and translocation to above-ground tissues such as leaves and stems. Concentrations of ${ }^{137} \mathrm{Cs}$ in leaves were generally greater than those in the sediments of Steel Creek (Briese et al., 1975; Garten et al., 1975a; Garten and Paine, 1977; Sharitz et al., 1975). Concentration ratios (1.e., the ratio of ${ }^{25} \mathrm{Cs}$ concentration in leaves to that in sediments) ranged from 3 to 10 in the Steel Creek system for wapato (Sagittaria latifolia), a commonly occurring emergent aquatic plant (Garten and Paine, 1977).
The concentrations of ${ }^{137} \mathrm{Cs}$ were measured in a large number of plant species (Table 5-1). The plants ranged from emergent aquatic plants such as wapato, smartweed, and bulrush to terrestrial plants that grow on drier areas such as broomsedge, black willow, tag alder, and wax myrtle. Concentrations varied among species, but sometimes varied as much among different samples of the same species as among species. For example, Sharitz et al. (1975), Briese et al. (1975), and Pinder and Sharitz (1978) report varying concentrations for wapato and smartweed, but the concentration for wapato was always greater than that for smartweed. Possible causes for variation among samples for the same species are variation in the levels of ${ }^{15} \mathrm{Cs}$ deposition (Anderson et al., 1973; Garten et al., 1975b; Briese et al., 1975) and changes in leaf concentrations with season (Garten et al., 1975b).

The variation among plant species in ${ }^{137} \mathrm{Cs}$ concentrations reflects variation in the uptake and accumulation of stable cesium (Figure 5-1). For samples of six emergent aquatic species [in order of increasing stable cesium concentrations: St. John's wort (Hypericum walteri), false nettle (Boehmeria cylindrica), smartweed, cutgrass (Leersia oryzoides), wapato, and Asian dayflower (Aneilema keisak) collected from the same area of Steel Creek in 1981 , the ${ }^{137} \mathrm{Cs}$ concentration in emergent aquatic species was correlated with the concentration of stable cesium and indicated a

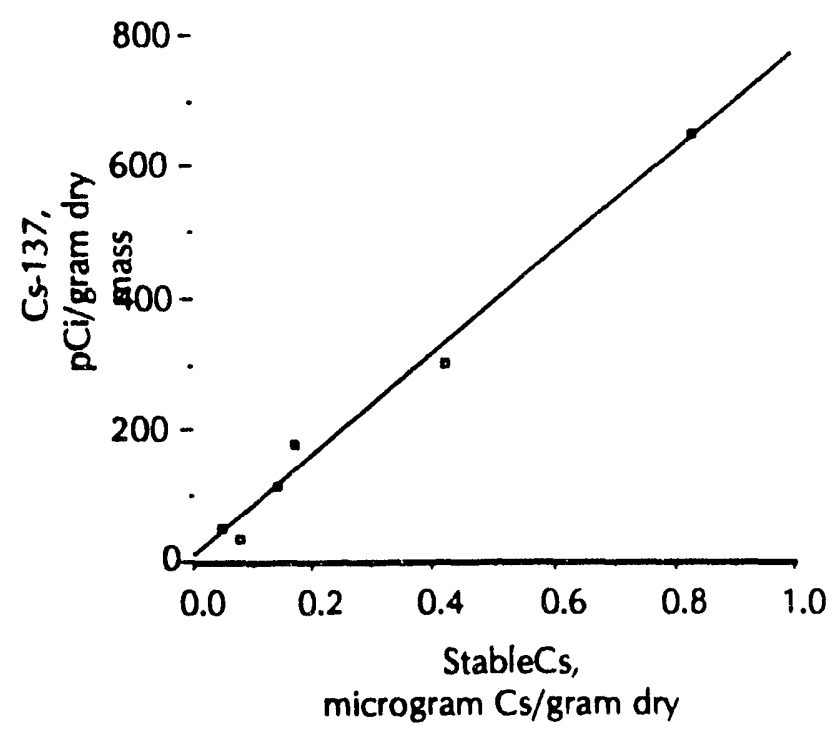

Figure 5-1. Relationship Between the Concentrations of ${ }^{13} \mathrm{Cs}$ and Stable Cs in Six Species of Emergent Aquatic PlantsGrowing in the Inundated Flood Plain of Steel Creek in 1981 
consistent ratio across species of $0.009 \mathrm{mg}{ }^{17} \mathrm{Cs}$ per $\mathrm{g}$ stable cesium (J. E. Pinder and J. J. Alberts, unpublished data).

There was also considerable variation in ${ }^{17} \mathrm{Cs}$ concentrations among individuals of a species growing in the same area (Garten et al., 1975c; Garten and Paine, 1977; Pinder and Sharitz, 1978; Sharitz et al., 1975). The largest concentrations observed in a sample of leaves for a given plant were often a factor of 10 greater than the smallest concentrations. This local variability in ${ }^{13} \mathrm{Cs}$ uptake was related to local variations in sediment composition as much as it was to variation in sediment ${ }^{137} \mathrm{Cs}$ concentrations. Sharitz et al. (1975) demonstrated that wapato and smartweed growing on fine sediments did not have greater leaf ${ }^{15} \mathrm{Cs}$ concentrations than those on coarse sediments despite a 10 -fold greater ${ }^{197} \mathrm{Cs}$ concentration in fine sediments (Table 5-1). By comparing ${ }^{137} \mathrm{Cs}$ concentrations in wapato leaves to sediment properties such as silt content. organic matter content, and extractable potassium $(K)$, it was determined that ${ }^{17} \mathrm{Cs}$ uptake was greatest from soils low in silt and organic matter content (Pinder et al., 1980). These trends are similar to those observed in laboratory studies of the factors affecting cesium uptake from soils.

The uptake of ${ }^{137} \mathrm{Cs}$ and stable cesium is a result of its similarity to $K$, which is a required element for plants. Although the plants in Stoel Creek were absorbing ${ }^{137} \mathrm{Cs}$ from the sediments and accumulating it in leaves, studies on ${ }^{13} \mathrm{Cs}$ and $\mathrm{K}$ concentrations in plant tissues and soils indicated that the uptake of cesium was proportionately less than that of K (Garten et al., 1975c). This was indicated by comparing the ratios of ${ }^{13} \mathrm{Cs}$ concentration to $\mathrm{K}$ concentration in leaves with the ${ }^{17} \mathrm{Cs}$ to $\mathrm{K}$ ratio in soil. Smaller ratios in leaves than in soil indicate less uptake of ${ }^{17} \mathrm{Cs}$ than $\mathrm{K}$. The ${ }^{17} \mathrm{Cs}$ to $\mathrm{K}$ ratio in bulrush leaves was only $8 \%$ of that in soil. The ratio of ${ }^{17} \mathrm{Cs}$ to $\mathrm{K}$ in broomsedge leaves was only $6 \%$ of that in soil.

\section{Concentrations of ${ }^{137} \mathrm{Cs}$ in Animals}

Concentrations of ${ }^{17} \mathrm{Cs}$ were measured in a variety of animals from the Steel Creek flood plain (Table 5-2). These concentrations were generally greater than those observed at other sites of ${ }^{137} \mathrm{Cs}$ deposition in the U.S. (Anderson et al., 1973; Garten et al., 1975c). The ${ }^{137} \mathrm{Cs}$ concentrations in animals were also variable with the ${ }^{137} \mathrm{Cs}$ concentrations in animals being correlated to those in plants (Anderson et al., 1973).

Although the ${ }^{17} \mathrm{Cs}$ concentrations in animals were generally greater than those at other sites, the ${ }^{137} \mathrm{Cs}$ transfers in the food chain from plants to herbivores and herbivores to carnivores were similar to those observed at other locations (Anderson et al., 1973). The ratio of ${ }^{17} \mathrm{Cs}$ concentration in herbivores to that in plants was approximately 0.5 . The ratio of ${ }^{137} \mathrm{Cs}$ concentration in carnivores to that in herbivores was approximately 1.0 . These ratios indicate no biomagnification of ${ }^{137} \mathrm{Cs}$ in the food chain.

\section{Declining ${ }^{137} \mathrm{Cs}$ Concentrations in Steel Creek Biota}

Evidence indicates that ${ }^{157} \mathrm{Cs}$ concentrations in the biota of the Steel Creek flood plain are declining at a rate greater than that expected for simple, physical decay of ${ }^{17} \mathrm{Cs}$. Bagshaw and Brisbin (1984) found a decline rate of approximately $20 \%$ per year for the ${ }^{137} \mathrm{Cs}$ concentrations in two species of water snakes. A decline rate of about $2 \%$ per year is expected due to physical decay. A comparison of ${ }^{15} \mathrm{Cs}$ concentrations in plants and animals between 1971 and 1981 indicated total declines in concentration ranging from 50\% to greater than 90\% (Brisbin et al., 1989). A total cocline of about 20\% is expected between 1971 and 1981 because of physical decay.

The rapid rate of decline may represent erosion of ${ }^{137} \mathrm{Cs}$ from Steel Creek or decreased availability of the ${ }^{137} \mathrm{Cs}$ to plants due to (1) continuing slow rates of chemical fixation in the sediments, or (2) burial of ${ }^{137} \mathrm{Cs}$ containing sediments by new sediments with lower ${ }^{17} \mathrm{Cs}$ concentrations. Whether this decline has been affected by the construction of L Lake or the resumption of $L$ Reactor operations is not known. 


\section{SREL Research in the Par Pond/Pond B System}

Studies of ${ }^{17} \mathrm{Cs}$ in the Par Pond and Pond B system have been almost as extensive as those in Steel Creek. Studies of ${ }^{17} \mathrm{Cs}$ in waterfowl and other organisms began in the early 1970s (Brisbin et al., 1973), and research has continued to the present. The research has often been conducted in conjunction with the staff of the Savannah River Laboratory (e.g., Alberts et al., 1979) or Argonne National Laboratory (e.g., Alberts et al., 1987). A principal result of these studies has been the documentation of the importance of ${ }^{17} \mathrm{Cs}$ remobilization from sediments to the water during periods of summer anoxia.

\section{Remobilization of ${ }^{137} \mathrm{Cs}$ from Sediments}

Lakes and ponds of the southeastern United States experience thermal stratification in the summer with isolation of the warmer, surface waters (termed the epilimnion) from deeper, cooler waters (termed the hypolimnion). This regularly occurs in Par Pond and Pond B (Chimney et al., 1985 ) with biological activity in the hypolimnion resulting in oxygen depletion, termed anoxia. Anoxia produces a reducing environment that causes release of $\mathrm{Fe}, \mathrm{Mn}$, and other metals from the sediments to the hypolimnion. Alberts et al. (1979) used data from the SRS Health Physics group to show that periods of summer anoxia were accompanied by increases in the ${ }^{137} \mathrm{Cs}$ concentrations in the 15 -m deep waters of Par Pond (Figure 5-2). This depth is part of the anoxic

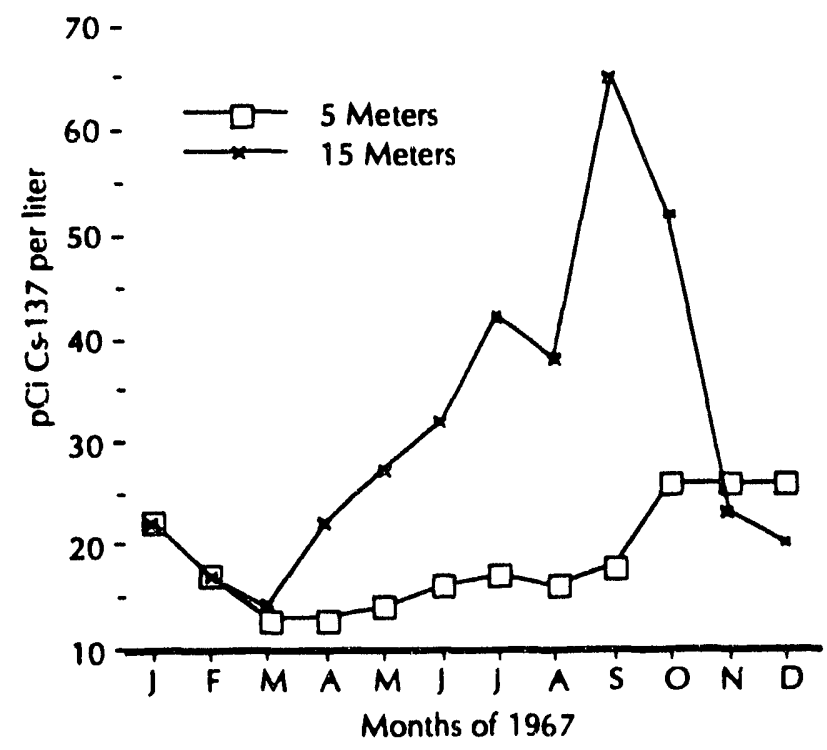

Ftgure 5-2. Concentrations of ${ }^{13} \mathrm{Cs}$ in Par Pond During 1967 hypolimnion from late April through mid November. During this time, the ${ }^{137} \mathrm{Cs}$ concentrations increase. The 5-m depth is part of the epilimnion during summer months and does not show increases in ${ }^{17} \mathrm{Cs}$ concentrations. The ${ }^{137} \mathrm{Cs}$ in the deeper waters is redistributed through the pond in the fall when thermal stratification breaks down and the surface and deeper waters are mixed. The ${ }^{17} \mathrm{Cs}$ concentration in the water then slowly declines until spring. A similar ${ }^{137} \mathrm{Cs}$ cycle was also demonstrated for Pond B (Alberts et al., 1987).

Thus, ${ }^{17} \mathrm{Cs}$ is not sequestered or immobilized in pond sediments although almost all of the ${ }^{137} \mathrm{Cs}$ is deposited in the sediments (Whicker et al., 1990). A small fraction of the ${ }^{15} \mathrm{Cs}$ in the sediments is annually remobilized to the water. The fraction of the ${ }^{137} \mathrm{Cs}$ in the sediments remobilized to the water is less than 1\% for Par Pond (Evans et al., 1983) and Pond B (Whicker et al., 1989, 1990). Remobilization of ${ }^{13} \mathrm{Cs}$ from the sediments apparently occurs for the same reason that ${ }^{137} \mathrm{Cs}$ remains available for root uptake in Steel Creek and Coastal Plain sites. As was observed in Steel Creek (Brisbin et al., 1974), the ${ }^{137} \mathrm{Cs}$ in the sediments of Par Pond and Pond $B$ are not fixed into unavailable forms. Evans Ct al. (1983) showed that $>20 \%$ of the ${ }^{17} \mathrm{Cs}$ was available and could be displaced from the sediments by other cations such as $\mathrm{K}^{+}, \mathrm{Na}^{+}$and ammonium ions, $\mathrm{NH}^{4+}$. This occurred because $>80 \%$ of the clay in the sediments is kaolinite. Less than $10 \%$ is illite.

Ammonium ions were especially effective in displacing ${ }^{15} \mathrm{Cs}$ from the sediments. They could displace approximately $20 \%$ of the ${ }^{17} \mathrm{Cs}$. Because $\mathrm{NH}^{4+}$ is generated by biological activity in the sediments, $\mathrm{NH}^{4+}$ production in the sediments is the likely driving force in remobilizing ${ }^{17} \mathrm{Cs}$. Other mechanisms, such as release of ${ }^{137} \mathrm{Cs}$ from $\mathrm{Fe}$ and $\mathrm{Mn}$ oxides, may also be occurring (Sholkovitz, 1985).

\section{Behavior of ${ }^{137} \mathrm{Cs}$ in Pond Foodchains}

The ${ }^{17} \mathrm{Cs}$ remobilized from the sediments becomes available for incorporation by aquatic organisms through either ion absorption from the water or assimilation from food. Macrophytes, rooted plants growing along the shallow margins of the ponds, may also accumulate ${ }^{137} \mathrm{Cs}$ by root uptake from the sediments. A number of SREL studies have shown ${ }^{17} \mathrm{Cs}$ accumulation by aquatic organisms in Par Pond and Pond B including waterfowl species (Brisbin et al., 1973; Brisbin and Vargo, 1982; Potter et al., 198\%), litule blue herons (Domby et al., 1977), slider turtles (Peters and 
Brisbin, 1988), mosquito fish (Newman and Brisbin, 1990), and American alligators (Brisbin, 1989).

Whicker et al. $(1989,1990)$ recently compiled an inventory of ${ }^{17} \mathrm{Cs}$ for Pond $\mathrm{B}$. A comparison of ${ }^{17} \mathrm{Cs}$ concentrations in various organisms is presented in Table 5-3. Table 5-3 also contains concentration ratios that compare the concentration in the organism with that in the water. The ${ }^{15} \mathrm{Cs}$ concentration in water was approximately $20 \mathrm{pCi} / \mathrm{L}^{-1}$.

As was the case in the Steel Creek flood plain, there was little evidence of biomagnification of ${ }^{137} \mathrm{Cs}$ concentrations in organisms in Pond B. There were only minor differences among organisms.

Although the concentrations for fish may appear greater than those for some macrophytes and benthic invertebrates, the concentrations of ${ }^{17} \mathrm{Cs}$ in fish muscle are greater than those in other tissues such as bone. When the ${ }^{17} \mathrm{Cs}$ concentrations are considered for all tissues, the overall concentrations in fish are smaller and more similar to other organisms (Whicker et al., 1989, 1990).

The concentration ratios for organisms in Pond B were as large or larger than at other aquatic sites of ${ }^{15} \mathrm{Cs}$ deposition (Whicker et al., 1989, 1990). The high ratios are apparently the result of the low $\mathrm{K}$ content of the water in Pond $\mathrm{B}$ which is acidic with low cation concentrations (Chimney et al., 1985). The high ratios in Pond B are consistent with other observations of high concentration ratios for ${ }^{17} \mathrm{Cs}$ in waters with low K concentrations (Blaylock, 1982).
Although the ${ }^{137} \mathrm{Cs}$ concentration ratios were large, the biota contained only a small fraction of the total ${ }^{137} \mathrm{Cs}$ contained in Pond B. Whicker et al., $(1989,1990)$ report that sediments contain $98.6 \%$ of the total inventory of ${ }^{15} \mathrm{Cs}$. The water contains $0.66 \%$ of the ${ }^{137} \mathrm{Cs}$ and the biota contains the rest. The biota and the water contain approximately equal amounts, but more than $90 \%$ of the fraction in the biota is contained in the macrophytes. The fish contain less than $0.01 \%$.

The Par Pond-Pond B system is extensively used by waterfowl (Brisbin, 1991). Some birds may be long-term residents whose ${ }^{137} \mathrm{Cs}$ concentrations are in equilibrium between their food intake rates and metabolic elimination rates. Other birds are migratory species that only spend a limited time on the ponds (Potter et al., 1989). These birds may accumulate ${ }^{137} \mathrm{Cs}$ from pond food chains and transport it $t$ offsite locations.

For migratory birds, their accumulation of ${ }^{137} \mathrm{Cs}$ is primarily dependent on their length of stay. Longer residence on the pond results in greater concentrations as birds accumulate ${ }^{17} \mathrm{Cs}$. Because accumulation is related to the length of residency, research has been conducted on the pattern of ${ }^{17} \mathrm{Cs}$ accumulation with time (Brisbin et al., 1990). These studies have shown that the early rates of accumulation are slower than those predicted by the simple, first-order kinetic models employed in most dose assessment codes. The accumulation of ${ }^{17} \mathrm{Cs}$ demonstrates a more sigmoid, second-order pattern that can be better described by other mathematical models. 


\section{Summary}

The Savannah River Ecology Laboratory has conducted studies of ${ }^{137} \mathrm{Cs}$ at a number of SRS locations, but research has been concentrated at two sites, the flood plain of Steel Creek and the Par Pond-Pond B reservoir system. The SREL studies in the Steel Creek flood plain have: (1) confirmed the previously observed availability of ${ }^{15} \mathrm{Cs}$ for plant uptake; (2) confirmed that the availability to plants is the result of a lack of fixation in the sediments; (3) demonstrated that considerable variability in ${ }^{137} \mathrm{Cs}$ concentrations may be expected among species and across locations; and, (4) shown that food chain transfers do not result in biomagnification of ${ }^{137} \mathrm{Cs}$ concentrations. Studies in Par Pond and Pond $\mathrm{B}$ have shown: (1) that most of the ${ }^{17} \mathrm{Cs}$ resides in the sediments of the ponds; (2) that a small fraction of the ${ }^{17} \mathrm{Cs}$ is remobilized to the water during summer anoxia; (3) that ${ }^{15} \mathrm{Cs}$ is available to the biota through this remobilization and by root uptake by macrophytes; and, (4) that ${ }^{17} \mathrm{Cs}$ concentrations in pond biota do not show biomagnification.

Although the flood plain of Steel Creek and the Par Pond/Pond B reservoir systems are different types of ecosystems, the behavior of ${ }^{13} \mathrm{Cs}$ is similar in the two systems in that ${ }^{17} \mathrm{Cs}$ availability is dependent on the presence of ksolinite in the sediments and that biomagnification of ${ }^{137} \mathrm{Cs}$ concentrations does not occur. 


\section{References}

Alberts, J. J., J. W. Bowling, and K. A. Orlandini, 1987, "The Effect of Seasonal Anoxia on the Distribution of ${ }^{200 \mathrm{Pu}}{ }^{20 \mathrm{Pu}},{ }^{200 \mathrm{Pu}}{ }^{211} \mathrm{Am},{ }^{24} \mathrm{Cm}$, and ${ }^{137} \mathrm{Cs}$ in Pond Systems of the Southeastern United States". Pinder, J. E., III, J. J. Alberts, K. W. McLood, and R. G. Schreckhise (eds.), Environmental Research on Actinide Elements, Office of Scientific and Techrical Information, U. S. Department of Energy, Washington, DC, pp. 371-390.

Albers, J.J., L.J. Tilly, and T.J. Vigerstad, 1979, “Seasonal Cycling of ${ }^{13} \mathrm{Cs}$ in a Reservoir", Science 203:649-651.

Anderson, G. E., J. B. Gentry, and M. H. Smith, 1973, "Relationships between Levels of Radiocesium in Dominant Plants and Arthropods in a Contaminated Stream Bed Community", Oikos 24:165-170.

Bagshaw, C., and I. L. Brisbin, Jr., 1984, "Long-Term Declines in Radiocesium of Two Sympatric Snake Populations", Journal of Applied Ecology 21:407-413.

Blaylock, B. G., 1982, "Radionuclide Databases Available for Bioaccumulation Factors for Freshwater Biota", Nuclear Safery 23:427-438.

Briese, L. A., C. T. Ganten, Jr., and R. R. Sharitz, 1975,"Distribution of Radiocesium in Vegetation Along a Contaminated Stream", Howell, F. G., J. B. Gentry, and M. H. Smith (eds.), Mineral Cycling in Southeastern Ecosystems, U.S. Energy Research and Development Administration, Washington, DC, pp. 509-517.

Brisbin, I. L., Jr., 1989, "Rodiocesium Levels in a Population of American Alligators: A Model for the Study of Environmental Contaminants in Free-Living Crocodilians", Proceedings of the Eighth Working Meeting of the Crocodile Specialists Group of the Species Survival Committee of the International Union for Conservation of Nature and Natural Resources, IUCN, Ave. du Mont Blanc, CH-1196, Gland, Switzerland, pp. 60-73.

Brisbin, I. L., Jr., 1991, “Avian Radicecology", In D. M. Power (ed.) Current Ornithology, Vol. 8, Plenum Publ. Co., pp.69-140.

Brisbin, I. L., Jr., R. J. Beyers, R. W. Dapson, R. A. Geiger, J. B. Gentry, J. W. Gibbons, M. H. Smith, and S. K. Woods, 1974, 'Patterns of Radiocesium in the Sedjments of a Stream Channel Contaminated by Production Reactor Effluents", Health Physics 27:19-27.

Brisbin, I. L.,Jr., D. D. Breshears, K. L. Brown, M.Ladd, M. H. Smith, M. W. Smith, and A. L. Towns, 1989, "Relationships between Levels of Radiocaesium in Com- ponents of Terrestrial and Aquatic Food Webs of a Contaminated Streambed and Flood Plain Community", Journal of Applied Ecology 26:173-182.

Brisbin, I. L., Jr., R. A. Geiger, and M. H. Smith, 1973, "Accumulation and Redistribution of Radiocaesium by Migratory Waterfowl Inhabiting a Reactor Cooling Reservoir", Environmental Behavior of Radionuclides Released in the Nuclear Industry, International Atomic Energy Agency, Vienna, Austria, ppl. 373-384.

Brisbin, I. L., Jr., M. C. Newman, S. G. McDowell, and E. L. Peters, 1990, "Prediction of Contaminant Accumulation by Free-Living Organisms: Application of a Sigmoidal Model", Environmental Toxicology and Chemistry 9:141-149.

Brisbin, I. L., Jr., and M. J. Vargo, 1982, "Four-Year Declines in Radiocesium Concentrations of American Coots Inhabiting a Nuclear Reactor Cooling Reservoir", Health Physics 43:266-269.

Chimney, M. J., W. R. Cody, and W. M. Starkel, 1985, "Final Report on the Water Quality, Phytoplankton, and Zooplankton of Par Pond and Pond B. I. Water Quality", Aiken, SC: Environmental and Chemical Services, Report DPST-85-789.

Cummings, S.L., L. Bankert, A. R. Garret, Jr., and J. E. Regnier, 1969, " ${ }^{137} \mathrm{Cs}$ Uptake by Oat Plants as Related to Soil Fixing Capacity", Health Physics 17:145-148.

Cummings, S. L., J. H. Jenkins, T. T. Fendley, L. Bankert, P. H. Bedrosian, and C. R. Porter, 1971, "17 Cs in WhiteTailed Deer as Related to Vegetation and Soils of the Southeastern United States", In. D. J. Nelson (ed.) Radionuclides in Ecosystems, USAEC Report CONF-710501-PI, pp. 123-128.

Dahlman, R. C., C. W. Francis, and T. Tamura, 1975, "Radiocesium Cycling in Soil and Vegetation", In F. G. Howell, J. B. Gentry, and M. H. Smith (eds.) Mineral Cycling in Southeastern Ecosystems, U. S. Energy Research and Development Administration CONF-7405 13, pp. 462-481.

Dapson, R. W., and L. Kaplan, 1975, “Biological Half-Life and Distribution of Radiocesium in a Contaminated Population of Green Treefrogs Hyla cinerea", Oikos 26:39-42.

Domby, A. H., D. Paine, and R. W. McFarlane, 1977, 'Radiocesium Dynamics in Herons Inhabiting a Contaminated Reservoir System", Health Physics 33:523-532. 
Evans, D. W., J. J. Alberts, and R. A. Clark, III, 1983, “Reversible Ion-Exchange Fixation of ${ }^{137} \mathrm{Cs}$ Leading to Mobilization from Reservoir Sediments", Geochimica el Cosmochimica Acta 47:1041-1049.

Garten, C. T., Jr., L. A. Briese, R. A. Geiger, R. R. Sharitz, and M. H. Smith, 1975a, "Radiocesium Levels in Vegetation Colonizing a Contaminated Flood Plain". Howell, F. G., J. B. Gentry, and M. H. Smith (eds.), Mineral Cycling in Southeastern Ecosystems, U. S. Energy Research and Development Administration, Washington, DC, 489-497.

Garten, C. T., Jr., L. A. Briese, R. R. Sharitz, and J. B. Gentry, 1975b, "Seasonal Variation in Radiocesium Concentrations in Three Tree Species", Howell, F. G., J. B. Gentry, and M. H. Smith (eds.), Mineral Cycling in Southeastern Ecosystems, U. S. Energy Research and Development Administration, Washington, DC, pp. 498-508.

Garten, C. T., Jr., J. B. Gentry, J. E. Pinder, III, R. R. Sharitz, and M.H. Smith, 1975c, "Radiocaesium Dynamics in a Contaminated Flood Plain Ecosystem in the Southcastern United States", Impacts of Nuclear Releases into the Aquatic Environment, Intemational Atomic Energy Agency, Vienna, Austria, pp. 331-347.

Garten, C. T., Jr., and D. Paine, 1977, "A Multivariate Analysis of Factors Affecting Radiocesium Uptake by Sagittaria latifolia in Coastal Plain Environments" , Journal of Environmental Quality 6:78-82.

Gladden, J. B., K. L. Brown, M. H. Smith, and A. Towns, 1985, "Distribution of Gamma Exposure Rates in a Reactor Effluent Stream Flood Plain System", Health Physics 48:49-59.

Jenkins, J. H., and T. T. Fendley, 1971, "Radionuclide Biomagnification in Coastal-Plain Deer", In: Nelson, D. J. (ed.) Radioecology, Proc. Third Natl. Symp. Radioecology, Oak Ridge National Laboratory, CONF-710501-PI, pp. 116-122.

Lomenick, T. F., and D. A. Gardiner, 1965, "The Occurrence and Retention of Radionuclides in the Sediments of White Oak Laken, Health Physics 11:567-577.

Newman, M. C., and I. L. Brisbin, Jr., 1990, "Variation of ${ }^{17} \mathrm{Cs}$ Levels between Sexes, Body Sizes and Collection Localities of Mosquitofish, Gambusia holbrooki
(Girard 1859), Inhabiting a Reactor Cooling Reservoir", J. Environmental Radioactivity 12:131-141.

Peters, E. L., and I. L. Brisbin, Jr., 1988, "Radiocaesium Elimination in the Yellowbellied Turtle (Pseudemys scripta)", Journal of Applied Ecology 25:461-471.

Pinder J. E., III, C. T. Garten, Jr., and D. Paine, 1980, "Factors Affecting Radiocesium Uptake by Plants Inhabiting a Contaminated Flood Plain", Oecologia Generalis 1:3-10.

Pinder, J.E., III, and R. R. Sharitz, 1978, "Variance Components of Radiocesium Concentrations in Plants Inhabiting a Contaminated Flood Plain", Oecologia Plantarum 13:111-120.

Potter, C. M., I. L. Brisbin, Jr., S. G. McDowell, and F. W. Whicker, 1989, "Distribution of ${ }^{13} \mathrm{Cs}$ in the American Coot (Fulica americana)", J. Environmental Radioactivity 9:105-115.

Sharitz, R. R., S. L. Scot, J. E. Pinder, III, and S. K. Woods, 1975, "Uptake of Radiocesium from Contaminated Flood Plain Sediments by Herbaceous Plants", Health Physics 28:23-28.

Sholkovitz, E. R., 1985, "Redox-Related Chemistry in Lakes: Alkali Metals, Alkaline-Earth Elements, and ${ }^{17} \mathrm{Cs}$ ", In W. Stumm (ed.) Chemical Processes in Lakes, John Wiley and Sons, New York, NY, pp. 119-142.

Staton, M. A., I. L. Brisbin, Jr., and R. A. Geiger, 1974, "Some Aspects of Radiocesium Retention in Naturally Contaminated Captive Snakes", Herpetologica 30:204-211.

Straney, D. O., B. Beaman, 1. L. Brisbin, Jr., and M. H. Smith, 1975, "Radiocesium in Birds of the Savannah River Plant", Health Physics 28:341-345.

Whicker, F. W., J.E. Pinder, III, J. W. Bowling, J.J. Albers, and I. L. Brisbin, 1989, "Distribution of ${ }^{137} \mathrm{Cs}$, ${ }^{80} \mathrm{Sr}$, ${ }^{20 \mathrm{Pu}}{ }^{20 \mathrm{Pu}}{ }^{21} \mathrm{Am}$, and ${ }^{24} \mathrm{Cm}$ in Pond B, Savannah River Siten, Savannah River Ecology Laboratory, Aiken, SC, Report SREL-35, UC-66e.

Whicker, F. W., J.E. Pinder, III, J. W. Bowling, J. J. Alberts, and I. L. Brisbin, 1990, "Distribution of Long-Lived Radionuclides in an Abandoned Reactor Cooling Reservoir", Ecological Monographs 60:471-496. 
Table 5-1. The Concentrations of ${ }^{137} \mathrm{Cs}$ in Leaves of Plants from the Flood Plain of Steel Creek. All samples collected between 1971 and 1975.

SPECIES,

CONCENTRATION

REFERENCE,

AND HABITAT
MEAN

(pCi/g dry mass)

Wapato (Sagittaria latifolia)

Sharitz et al. (1975)

Coarse soils

Fine soils

Pinder and Sharitz (1978)

725

Briese et al. (1975)

490

Garten and Paine (1977)

750

Smartweed (Polygonum punclatum)

Sharitz et al. (1975)

Coarse soils

Fine soils

Pinder and Sharitz (1978)

Briese et al. (1975)

Bulrush (Scirpus cyperinus)

Garten et al. (1975a)

Briese et al. (1975)

Broomsedge (Anropogon spp.)

Anderson et al. (1973)

Floodplain

Islands

Garten et al. (1975a)

Black willow (Salix nigra)

Anderson et al. (1973)

Floodplain

Islands

Garten et al. (1975b)

240

Briese et al. (1975)

Tag alder (Alnus serrulata)

Anderson et al. (1973)

Floodplain

Islands

Garten et al. (1975b)

Wax myrtle (Myrica cerifera)

Anderson et al. (1973)

Floodplain

Islands

Garten et al. (1975b) 
Table 5-2. The Concentrations of ${ }^{17} \mathrm{Cs}$ in Animals Collected from the Flood Plain of Steel Creek Between 1971 and 1975

SPECIES, MEAN

CONCENTRATION

REFERENCE,

AND HABITAT

(pCi/g dry mass)

Beetles (Coleoptera)

Anderson et al. (1973)

Floodplain

440

Islands

990

Grasshoppers (Orthoptera)

Anderson et al. (1973)

Floodplain

400

Islands

280

Leafhoppers and aphids (Homoptera)

Anderson et al. (1973)

Floodplain

150

Islands

660

Spiders (Araneae)

Anderson et al. (1973)

Floodplain

260

Islands

970

Tree frogs (Hyla cinerea)

Dapson and Kaplan (1975)

190

Water snakes (Natrix spp.)

Staton et al. (1974)

120

Herbivorous birds

Straney et al. (1975)

Camivorous birds

Straney et al. (1975)

10

Cotton rats (Sigmodon hispidus)

Garten et al. (1975c)

610

Rice rats (Ory-omys palustris)

Garten et al. (1975c)

210 
Table 5-3. The Concentrations of ${ }^{157} \mathrm{Cs}$ in Organisms Collected from Pond B in 1983 and 1984. Data are from Whicker et al. (1989, 1990).

FORM AND SPECIES

Macrophytes

Water lilly (Nymphaea odorata)

Fanwort (Cabomba caroliniana)

Water shield (Brassenia schreberi)

Benthic Invertebrates

Dragonfly larvae

Horsefly larvae

Turile muscle

Slider turtle (Trachemys scripta)

Fish muscle

Largemouth bass (Micropterus salmoides)

Bullhead (Ictalurus natalis)

Waterfowl muscle

American coot (Fulica americana)
390

760

510

200

130

270

800

590

390

\section{CONCENTRATION}

RATIO

(pCi/g dry mass)
19,000

37,000

25,000

10,000

6,500

13,000

39,000

29,000

19,000 


\section{Chapter 6. Assessment of Dose/Risk from SRS Radiocesium Releases}

This chapter describes the health impacts associated with exposure to radiocesium. The methodology used to produce dose estimates is presented. The results of a dose assessment for radiocesium releases during the 1954-1989 period are discussed. 


\section{Relationship of Dose to Risk and Health Effects}

\section{Ionizing Radiation}

Ionizing radiation is radiation that has enough energy to remove electrons from the atoms through which it passes. The interaction of ionizing radiation with biological systems can induce a series of chemical reactions that can cause permanent changes in the genetic material of cells. These changes (mutations) may cause abnormal functioning within the cell or may lead to cell death.

The nature of radiation-induced cellular changes is dependent upon the magnitude of the dose and the rate at which it is received. For the low doses and dose rates encountered in the environment from SRS releases, the most significant effect is cancer induction.

This is believed to be a stochastic effect (i.e., an increase in dose increases the probability of the effect, but the severity of the effect is independent of the dose).

A characteristic of stochastic risks is the absence of a threshold. In other words, it is conceivable that any dose of radiation, no matter how small, might give rise to a cancer. On the other hand, there is no way to be certain that a given dose, no matter how large, will cause a cancer in an individual.

\section{Cancer Risk Estimates}

The most comprehensive estimates of cancer induction by exposure to ionizing radiation come from studies of the atomic bomb survivors at Hiroshima and Nagasaki. Less definitive studies include those of medical patients exposed to therapeutic and diagnostic radiation. Studies of laboratory animals have increased the understanding of dose-effect relationships. The International Commission on Radiological Protection (ICRP) has evaluated all of these studies and concluded that the best estimate of lifetime risk of fatal cancer for members of the general population is approximately 500 cases per 1,000,000 person-rem. This is equivalent to one case per 2000 person-rem (ICRP, 1991). 


\section{Radiocesium Exposure and Dose to Man}

\section{Distribution and Retention of Cesium in the Human Body}

Nawrally occurring cesium $\left({ }^{133} \mathrm{Cs}\right)$ is an essential trace constituent in the human body, which contains an average of 1.5 milligrams. The chemical behavior of cesium is similar to potassium. Cesium is uniformly distributed throughout the body and the concentration in any organ or tissue is no greater than the concentration in muscle (ICRP, 1979).

Radioisotopes of cesium have the same biochemical behavior in the human body as naturally occurring cesium (i.e., they are uniformly distributed throughout the body). Radiocesium isotopes released to the environment from the nuclear industry and from weapons test fallout can exist in a variety of organic and inorganic forms. After transport in the environment, exposure to man may occur by inhalation and by ingestion of food and water.

\section{Cesium Dosimetry}

Cesium is rapidly absorbed from the gastrointestinal tract and the lungs and is distributed uniformly throughout the body (ICRP, 1979). The retention of cesium may be represented by a two-compartment system. Of the total amount of cesium taken into the body, $10 \%$ is excreted with a biological half-life of 2 days and $90 \%$ is excreted with a biological half-life of 110 days. Cesium retention may be expressed mathematically as

$$
R(t)=0.1 \mathrm{e}^{-0.693 \mathrm{~L} / 2}+0.9 \mathrm{e}^{-0693 \mathrm{~V} / 110}
$$

where

$$
\begin{aligned}
R(t) & =\text { fractional retention in the body } \\
t & =\text { time in days. }
\end{aligned}
$$

In 1988, the Department of Energy issued internal dose conversion factors to ensure that doses are calculated in a consistent manner at all DOE facilities (DOE, 1988). The factors are based on ICRP recommendations (ICRP, 1979). These dose factors are used in conjunction with the models described in the subsection on models of radiocesium transport and dose, to calculate all the doses reported in this document.

Future changes are anticipated in the dose calculation methodology. The ICRP (ICRP, 1989) has recently issued age specific dose factors for ingestion of some of the more common isotopes and is currently developing age specific dose factors for inhalation of radioisotopes. 


\section{Modcls of Radiocesium Transport and Dose}

With the exception of tritium, most of the radioactive materials currently released from SRS have such low concentrations in the offsite environment that they are not detectable by conventional monitoring techniques. Therefore, radiation doses to offsite individuals and populations are calculated with mathematical models. These models use known transport mechanisms for atmospheric and liquid releases and known major pathways of exposure to man. Modeled atmospheric and aqueous dispersion are periodically verified using environmental tritium measurements (tritium is released during normal SRS operations).

The first models used at SRS for calculating offsite doses were developed by the Savannah River Laboratory (Cooper, 1975). These models, MREM (atmospheric releases) and RIVDOSE (liquid releases), were first used in 1972. In 1982, MREM and RIVDOSE were replaced with more technologically advanced models that are currently in use.

SRS annual offsite doses are currently calculated with the transport and dose models developed for the commercial nuclear industry (NRC, 1977a: NRC, 1977b). The models are implemented at SRS in the following computer programs:

\section{Atmospheric Releases}

- MAXIGASP - calculates maximum and average doses to offsite individuals

- POPGASP - calculates offsite population collective dose

\section{Liquid Releases}

- LADTAP I - calculates both maximum and average doses to offsite individuals and collective dose to offsite populations.

MAXIGASP and POPGASP are SRL-modified versions of the Nuclear Regulatory Commission (NRC) programs XOQDOQ (Sagendorf et al., 1982) and GASPAR (Eckerman et al., 1980). The modifications were made to meet the requirements for input of physical and biological data that are specific to SRS. The basic calculations in the $X O Q D O Q$ and GASPAR programs have not been modified. LADTAP II (Simpson and McGill, 1980) is an essentially unaltered version of the NRC code of the same name.

\section{Modeling Atmospheric Dispersion of Radioactive Releases}

The routine atmospheric transport of radioactive materials from the SRS is evaluated on the basis of meteorological conditions measured continuously at seven onsite towers. The towers relay wind speed, direction, and atmospheric stability information at 1.5 second intervals to the Savannah River Laboratory via the WIND (Weather Information and Display) system. A database of this information containing the $60-\mathrm{min}$ average values for the period $1982-1986$ is accessed by the dispersion codes to estimate downwind concentrations of released radionuclides.

Historically, offsite doses have been calculated assuming the releases occurred at the geographic center of the site and $H$ Area meteorology was used. It has been demonstrated that using data from one of the other onsite meteorological towers has little effect on the maximum individual dose and no effect on the 50-mile population dose (Hamby and Parker, 1991).

The dispersion of an atmospheric release from SRS is modelled using XOQDOQ. XOQDOQ computes concentrations in the plume as a function of downwind distance and compass sector. At the user's option, the plume can be depleted due to dry deposition and/or radioactive decay. Also, at the user's option, plume concentrations can be reduced by taking into account the upward displacement of the effluent resulting from thermal buoyancy and/or momentum effects. This option is not used at SRS (i.e., no credit is taken for plume rise).

The plume concentration information generated by XOQ$D O Q$ is then used by the dose modeling program GASPAR to estimate doses to offsite individuals and populations. GASPAR estimates doses from a number of pathways which are illustrated in a general sense in Figure 6-1.

The doses estimated by GASPAR are reported on a pathway-specific basis as follows:

- Plume - extemal dose from radioactive materials suspended in the atmosphere

- Ground - external dose from radioactive materials deposited on the ground 


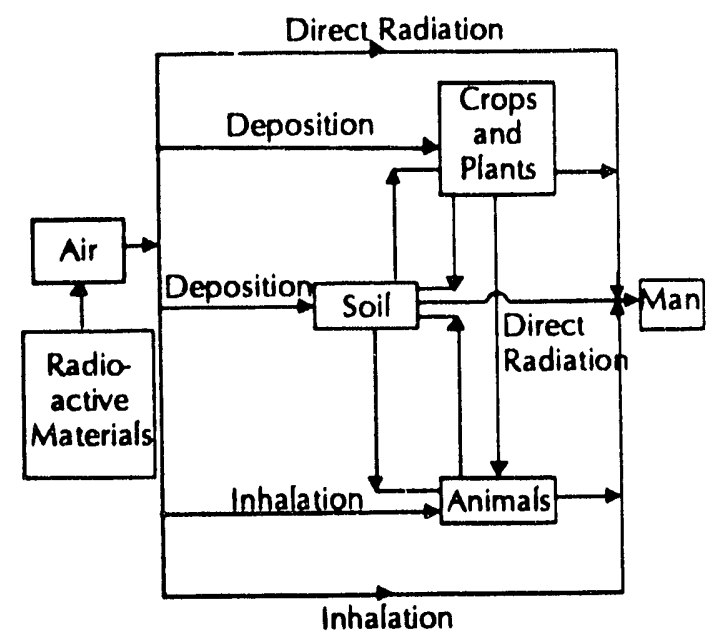

Figure 6-1. Simplified Pathways Between Radioactive Materials Released to the Atmosphere and Man

- Inhalation - internal dose from inhalation of radioactive materials present in the plume

- Vegetation - internal dose from consumption of contaminated crops

- Milk - internal dose from milk produced in a contaminated area

- Meat - internal dose from consumption of meat produced in a contaminated area.

XOQDOQ has undergone a comprehensive review in association with the Westinghouse Savannah River Company quality assurance requirements for software (Baver, 1991).

\section{MAXIGASP}

The calculations required by XOQDOQ and GASPAR to estimate maximum and average individual doses are performed at SRS using the computer program MAXIGASP. MAXIGASP calculates annual average groundlevel air concentrations and 50-yr committed doses at a number of points along the site boundary in each of 16 compass sectors.

The main outputs from the program are the maximum dose equivalents 10 an individual along the Site perimeter. The maximally-exposed individual is assumed to reside continuously at the location of highest exposure and to have living and eating habits that maximize his dose. These assumptions provide a ceiling on doses from atmospheric releases as no such individual is believed to exist.
The parameters used to calculate doses with MAXIGASP are presented in Table 6-1.

\section{POPGASP}

The calculations required by XOQDOQ and GASPAR to estimate population doses from atmospheric releases are performed at SRS using POPGASP. POPGASP calculates annual average ground-level air concentrations and annual doses for each of 160 regions ( 16 wind direction sectors at 10 distances per sector) within an 80-kilometer radius of the release location.

In addition to compass sector-specific meteorological information, POPGASP uses sector-specific data on population distribution and composition. Comparable data on milk, meat, and vegetable production and consumption are also used in the code. These databases are quite extensive and are available for review in the SRS environmental reports published annually. With respect to the human parameters used in POPGASP, the key values are shown in Table 6-1.

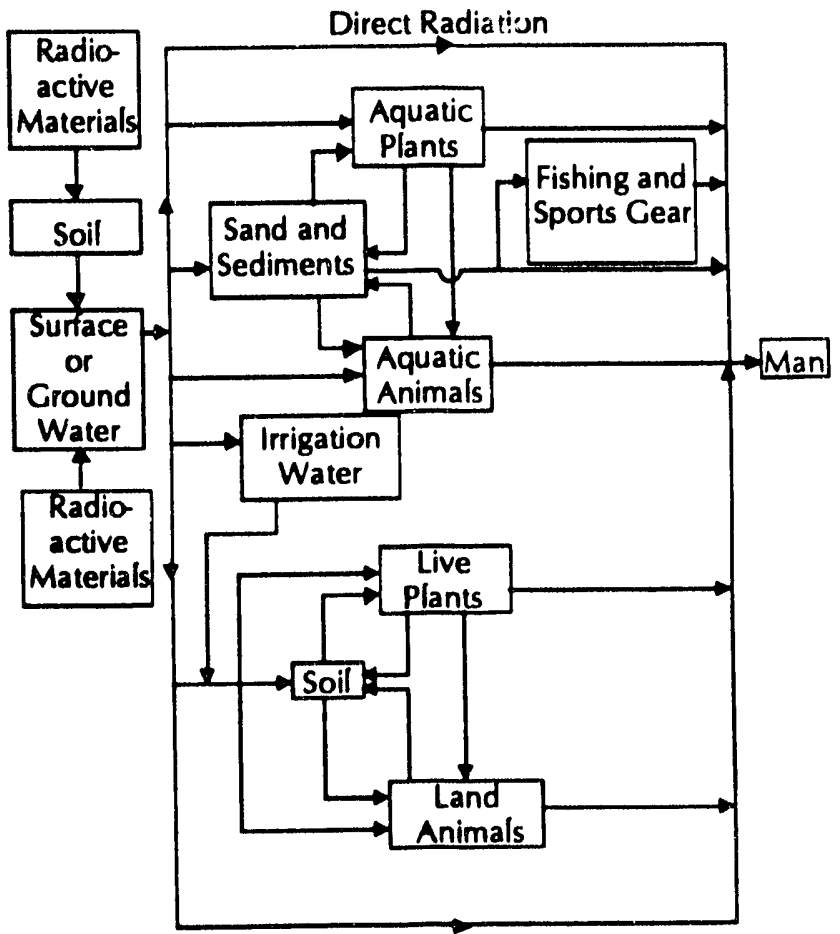

Figure 6-2. Simplified Pathways Between Radioactive Materials Released to Ground or Surface Waters and Man 


\section{Modeling Doses from Liquid Releases}

The consequences of liquid releases from SRS are modeled using LADTAP II (Liquid Annual Doses To All Persons). The potential pathways of exposure from liquid releases to the environment are shown in Figure 6-2. The pachway-specific doses calculated by LADTAP are grouped into the following five categories:

- Potable drinking water - internal dose from consuming drinking water of Savannah River origin

- Sports fish and commercial fish - internal dose from consuming fish of Savannah River origin

- Salt water invertebrates - internal dose from consuming shell fish from estuaries of the Savannah River

- Recreation - external dose from recreation activities in and along the Savannah River (boating, swimming, and shoreline activities)

- Irrigation - internal dose from foods produced by irrigation with Savannah River water (there are no known users of the river for this purpose)

LADTAP estimates individual and population doses at specific downstream locations. The only removal mechanism included in the transport model as it is used at SRS is radioactive decay. No credit is taken for adsorption on stream sediments.
The major assumption inherent in the application of LADTAP to SRS releases is that liquid discharges undergo complete mixing in the Savannah River before reaching potentially exposed populations. This assumption is supported by repeated measurements indicating that complete mixing occurs in the river between SRS and the Highway 301 sampling station (Cummins et al., 1990a).

LADTAP II generates maximum individual and population doses for all of the exposure pathways identified above. Though standard input values are provided in LADTAP II, SRS calculations are performed with site-specific information. Summary tables of principal input values used in the SRS version of LADTAP II are shown in Table 6-2. Additional site specific parameters for liquid releases are shown in Table 6-3.

Radioisotope concentrations in the Savannah River are diluted by the inflow of streams downriver from the SRS. Additional dilution occurs at the Beaufort-Jasper water treatment plant due to the inflow of surface water and at the Port Wentworth water treatment plart due to the close proximity of Abercom Creek to the intake. Since tritium is readily measured in the processed water of each system, a derived river flow rate can be calculated that allows betuer estimates of radionuclide concentrations at these treatment plants. 


\section{Validation of Transpost Models Using Monitoring Data}

\section{Atmospheric Releases}

The radionuclide concentrations predicted by XOQDOQ are routinely compared with measured values of tritium concentrations in air to evaluate the performance of the code. (Tritium is the only radionuclide released by the SRS that can be routinely detected offsite using conventional measuring techniques.) Predicted values tend to exceed observed values, yet not to a degree that would indicate an excessively conservative approach.

Other comparisons of predicted and measured concentrations have been made (Marter, 1984) and have exhibited similar results. The available data suggest that calculated concentrations of tritum in air arc generally conservative estimates of actual offsite values.

\section{Liquid Releases}

Throughout the period 1954-1989, drinking water doses from routine $S R S$ releases have been dominated by tritium. Measured, rather than estimated, tritium concentrations are therefore used for the downriver locations that are the most important in terms of dose calculations, (1) just below the SRS, (2) at the Beafort-Jasper water treatment plant, and (3) at the Port Wentworth water treatment plant In addition to supplying measured tritium concentrations, such data also allow calculation of Savannah River dilution factors for these locations. The availability of accurate estimates of river dilution characteristics significantly enhances the ability to predict downriver concentrations of other radionuclides such as radiocesium. 


\section{Impact of SRS Radiocesium Reieases on the Offsite Population}

The computer codes MAXIGASP, POPGASP, and LADTAP II have been used to calculate effective dose equivalents that have been theoretically received by segments of the offsite population from radiocesium $\left({ }^{137} \mathrm{Cs}\right)$ exposure over the course of site operations. The results are shown are in Tables 6-4 and 6-5 for doses attributable to atmospheric and liquid releases, respoctively. Liquid radiocesium release levels have consistently exceeded atmospheric release levels, and this trend is reflected in the doses to the offsite populations reported in the tables.

\section{Doses from Atmospheric Releases}

As shown in Table 6-4, the largest annual effective dose equivalent theoretically received by an adult occurred in 1955. The effective dose equivalent from ${ }^{13} \mathrm{Cs}$ to the "maximum" adult at the site perimeter in 1955 was 0.129 mrem.

"Maximum" individuals are hypothetical persons who lived at the SRS boundary and subsisted on diets of locally produced milk, meat, and vegetables. No such individuals are known to exist. Nevertheless, if one examines the case of the maximum adult individual living continuously at the site perimeter throughout the period 1954-1989, the cumulative effective dose equivalent from atmospheric releases of ${ }^{17} \mathrm{Cs}$ has been estimated as $0.334 \mathrm{mrem}$ (Table 6-4). This value is the upper bounding case and would make a minor contribution to the overall dose received during that time period.

A person living in the Central Savannah River Area would have received an effective dose of approximately 10,620 mrem from exposure to natural sources of radicactivity and an additional $2340 \mathrm{mrem}$ from medical practices and various consumer products during the 36-year period (Cummins et al., 1990b). Therefore, the cumulative dose contribution to this individual from SRS atmospheric radiocesium releases can be estimated as $0.0026 \%$.

Because the contribution of SRS radiocesium releases to any one individual's total radiation dose is so small, it is necessary to pool the radiation exposures from a given population if an assessment of potential health risks is desired. The population dose within an 80-kilometer radius is the figure-of-merit frequently used to make such an assessment.
The population doses reported in Table 6-4 are based on 1980 census data ( 555,100 people within $80 \mathrm{~km}$ ) and current meteorological and dose factor data. If it is assumed that this population has lived in the SRS vicinity throughout the period of site operation, the total collective effective dose received by that population through 1989 would be 36.5 person-rem.

The risks associated with this collective dose are quite small. The risk estimate using the ICRP factor for the number of excess fatal cancers potentially induced by a collective dose of 36.5 person-rem is 0.02 . Conversely, in that small population, at the current fatal cancer frequency of $16 \%$ (EPA, 1989b), there will be on the order of 90,000 spontaneous fatal cancers from all other causes. Therefore, it is impossible to demonstrate that a relationship exists between any of the cancer deaths occurring in this population and the releases of radiocesium to the atmosphere from SRS.

\section{Doses from Liquid Releases}

Dose equivalents potentially received by downstream consumers of Savaznah River water and fish are shown in Table 6-5. The dose calculations are based on 35\% of the total number of curies of ${ }^{137} \mathrm{Cs}$ released directly to onsite streams each year. It was shown in Chapter 4 that $65 \%$ of the ${ }^{17} \mathrm{Cs}$ released to streams is still on the SRS site. The release levels reflect contributions from all known effluents. Dose equivalents have been calculated for a "maximum" individual living just below the SRS who subsists on a diet of untreated Savannah River water and fish of Savannah River origin. Such doses are believed to represent the bounding case for liquid radiocesium releases. Drinking water doses have also been calculated for "maximum" individuals at both of the downstream water treatment plants and for the populations served by the water treatment plants.

The maximum doses occurred in 1963. The effective dose equivalent to the maximum individual for that year has been estimated as $10 \mathrm{mrem}$. If the hypothetical "maximum" exposure conditions are used as the bounding case for the 36-year period of site operation considered here, the cumulative effective dose to such an individual would be on the order of $60 \mathrm{mrem}$. Approximately $92 \%$ of this dose is 
due to eating fish from the Savannah River and most of the remainder $t o$ drinking untreated river water.

Since this individual's dose from non-SRS sources of radiation for that same time period would have exceeded $12,000 \mathrm{mrem}$, it may be concluded that the contribution to downstream individual doses by SRS radiocesium releases is insignificant.

With respect to the effect of liquid ${ }^{137} \mathrm{Cs}$ releases on the populations downstream of the SRS (Hamby, 1991), drinking water doses for users of the Beaufort-Jasper, South Carolina (50,000 customers) and Port Wentworth, Georgia, (15,000 effective consumers) water treaument plants have also been estimated. Different terminology is used to describe the two populations to reflect the difference in their compositions. The Beaufort-Jasper plant services residential areas and therefore provides full-scale domestic water service. The Port Wentworth facility serves a commercial complex in which contact with treated Savannah River water is currently limited to industrial workers who consume tap water. In past years, however, a locally-operated soft drink bouling facility may have presented an additional pathway of exposure.

If the cumulative effective doses received by both of these water treatment plant populations are surnmed, the collective dose equivalent would be on the order of 8.4 personrem. Using the ICRP nominal risk factor, the predicted impact of this collective dose is an estimated 0.004 excess fatal cancers in a population of 65,000 people $-10,400$ of whom, at the current fatal cancer rate, are projected to succumb to cancer from all other sources.

The total population dose for liquid releases is the sum of the dose from the water treatment plant pathway (8.4 personrem, 65,000 people) plus the dose due to other liquid pathways such as fish (116.6 person-rem, 550,000 people). The collective dose equivalent is 125 person-rem distributed among 615,000 people. The nominal risk factor predicts 0.06 fatal cancers in a population of 615,000 people $-98,000$ of whom will die of cancer from other sources. 


\section{Comparisons of Radiocesium Doses Near SRS with Applicable Regulations}

\section{Atmospheric Releases}

The highest hypothetical annual effective dose received by the maximally exposed individual due to atmospheric releases of radiocesium from SRS was $0.129 \mathrm{mrem}$ in 1955 (Table 6-4). The current EPA annual limit on doses to members of the public due to atmospheric releases is 10 mrem. The current DOE limit on doses to the general public from all releases, is 100 mrem.

\section{Liquid Releases}

Radiocesium doses from drinking water sources are evaluated based on the EPA annual drinking water standard of 4 mrem. As shown in Table 6-5, at no time during site operations has a drinking water dose from SRS radiocesium releases to the Savannah River exceeded $0.1 \mathrm{mrem}$. It is important to note that the dose limits described above are meant to be applied to all releases of radioactivity, not just ${ }^{17} \mathrm{Cs}$. The SRS, based on radiocesium or total releases, is consistently a minor contributor to radioactivity levels in the SRS environment. 


\section{Summary of Dosimetric Impacts}

The overall radiological impact of SRS radiocesium releases (1954-1989) on the offsite maximum individual can be characterized by total doses of $0.33 \mathrm{mrem}$ (atmospheric) and $60 \mathrm{mrem}$ (liquid). During this same period, however, such an individual received a dose of approximately 12,960 mrem from other sources of ionizing radiation present in the environment.

The impact of SRS radiocesium releases on offsite populations has also been evaluated. The total collective dose from atmospheric radiocesium releases (1954-1989) is estimated as 36.5 person-rem distributed among 555,100 individuals.
The total collective dose from liquid radiocesium releases for the same period was 125 person-rem distributed among the 555,100 individuals listed above plus an additional 65,000 individuals who obtain their drinking water from the Savannah River. These collective doses are minor components of the doses received from other environmental sources.

Radiocesium releases from SRS have decreased dramatically over the course of Site operations. Releases of ${ }^{15} \mathrm{Cs}$ from SRS present a negligible risk to the offsite environment and the population it supports. 
Table 6-1. Site Specific Parameters for Atmospheric Releases

\section{Population Group}

50-mile radius

Maximum Individual MAXIGASP

\section{Exposure Pathway}

Inhalation $\left(\mathrm{m}^{3 /} / \mathrm{yr}\right)$

Ingestion

Cow's milk ( $L / y r)$

Meat (kg/yr)

Leafy vegetables $(\mathrm{kg} / \mathrm{yr})$

Fruits, grains, and other

leafy vegetacles $(\mathrm{kg} / \mathrm{yr})$

External exposure

Transmission factor for

shielding from buildings

43

276

0.7

General Population (POPGASP)

\section{Exposure Pathway}

Inhalation $\left(\mathrm{m}^{3} / \mathrm{yr}\right)$

Ingestion

Cow's milk (L/yr)

Meat (kg/yr)

Leafy vegetables (kg/yr)

Fruits, grains, and other

leafy vegetables $(\mathrm{kg} / \mathrm{yr})$

43

21

External exposure

Transmission factor for shielding from buildings 
Table 6-2. Site Specific Parameters for Liquid Releases

\section{Maximum Individual Dose Assessments (LADTAP II)}

\section{Site Parameters}

Savannah River flow rate, $\mathrm{ft}^{3} / \mathrm{sec}$

Transit time from SRS to Savannah River, hr

Shore width factor

Cesium bicaccumulation factor

Human Parameters

Water consumption (L/yr) (a)

Fish consumption (kg/yr)

Shellfish consumption (kg/yr)

Shoreline recreation $(\mathrm{hr} / \mathrm{yr})$

Swimming ( $\mathrm{hr} / \mathrm{yr})$

Boating (hr/yr)
6,000 or measured average

24

0.2

3,000

\section{Maximum Individual}

$370(730)$
19
8
23
8.9
21

(a) The values in parentheses are EPA parameters mandated for use when calculating maximum individual doses to Beaufor-Jasper and Por Wentworth water users. 
Table 6-3. Additional Site Specific Parameters for Liquid Releases

A verage Individual/Population Dose Assessments (LADTAP II)

\section{Site Parameters}

Savannah River flow rate, $\mathrm{ft}^{3} / \mathrm{sec}$

Transit time from SRS to Savannah River, hr

Transit time from SRS wo water treatment plants, hr

Retention time in water treatment system, hrs

Shore width factor

River dilution in estuary

Cesium bioaccumulation factor

Aquatic food harvest, edible portions (kg/yr)

Sport fish

Commercial fish

Salt water invertebrates

\author{
10,000 or measured average \\ 24 \\ 72 \\ 24 \\ 0.2 \\ 3 \\ 3,000 \\ 35,000 \\ 2,700
}

Average Individual

\section{Human Parameters}

Water Consumption (L/yr) (a)

Fish Consumption (kg/yr)

Shellfish Consumption (kg/yr)

370

9

2

Usage (person-hr)

Shoreline Recreation (hr/yr)

960,000

Swimming (hr/yr)

Boating (hr/yr)
160,000

$1,100,000$ 
Table 6-4. Offsite Doses From Atmospheric Releases of ${ }^{24} \mathrm{Cs}$ and ${ }^{17} \mathrm{Cs}$

\begin{tabular}{|c|c|c|c|c|c|}
\hline \multirow[b]{2}{*}{ Year } & \multirow{2}{*}{$\begin{array}{l}{ }^{130} \mathrm{Cs} \\
\text { Release } \\
\mathrm{Ci} / \mathrm{yr}\end{array}$} & \multirow{2}{*}{$\begin{array}{l}{ }^{15} \mathrm{Cs} \\
\text { Release } \\
\mathrm{Ci} / \mathrm{Yr}\end{array}$} & \multicolumn{2}{|c|}{$\begin{array}{l}\text { CEDE (b) (c) } \\
\text { mrem }\end{array}$} & \multirow{2}{*}{$\begin{array}{l}\text { EDC }(d) \\
\text { person-rem } \\
\text { 80-km Pop }\end{array}$} \\
\hline & & & Max Ind & A verage Ind & \\
\hline $\begin{array}{l}1955 \\
1956 \\
1957 \\
1958 \\
1959 \\
1960 \\
1961 \\
1962 \\
1963 \\
1964 \\
1965 \\
1966 \\
1967 \\
1968 \\
1969 \\
1970 \\
1971 \\
1972 \\
1973 \\
1974 \\
1975 \\
1976 \\
1977 \\
1978 \\
1979 \\
1980 \\
1981 \\
1982 \\
1983 \\
1984 \\
1985 \\
1986 \\
1987 \\
1988 \\
1989\end{array}$ & $\begin{array}{l}\text { n.a. } \\
\text { n... } \\
\text { n.a. } \\
\text { n.a. } \\
\text { n.a. } \\
\text { n.a. } \\
\text { n.a. } \\
\text { n.a. } \\
\text { n.a. } \\
\text { n.a. } \\
\text { n.a. } \\
\text { n.a. } \\
\text { n.a. } \\
\text { n.a. } \\
\text { n.a. } \\
\text { n.a. } \\
5.08 E-03 \\
1.553-03 \\
0.00 \mathrm{E}+00 \\
3.00 \mathrm{E}-05 \\
2.00 \mathrm{E}-04 \\
1.70 \mathrm{E}-04 \\
4.33 \mathrm{E}-04 \\
1.25 \mathrm{E}-04 \\
2.68 \mathrm{E}-04 \\
3.08 \mathrm{E}-04 \\
6.41 \mathrm{E}-04 \\
3.80 \mathrm{E}-05 \\
5.60 \mathrm{E}-05 \\
3.80 \mathrm{E}-05 \\
3.00 \mathrm{E}-05 \\
6.94 \mathrm{E}-04 \\
3.55 \mathrm{E}-02 \\
6.58 \mathrm{E}-04 \\
9.20 \mathrm{E}-05\end{array}$ & $\begin{array}{l}1.35 \mathrm{E}+00 \\
2.39 \mathrm{E}-01 \\
6.27 \mathrm{E}-02 \\
2.59 \mathrm{E}-02 \\
1.38 \mathrm{E}-01 \\
1.24 \mathrm{E}-01 \\
2.48 \mathrm{E}-02 \\
3.70 \mathrm{E}-02 \\
2.52 \mathrm{E}-02 \\
6.67 \mathrm{E}-02 \\
1.77 \mathrm{E}-02 \\
4.82 \mathrm{E}-02 \\
1.81 \mathrm{E}-02 \\
4.03 \mathrm{E}-02 \\
8.53 \mathrm{E}-02 \\
4.15 \mathrm{E}-02 \\
9.33 \mathrm{E}-03 \\
2.44 \mathrm{E}-03 \\
2.58 \mathrm{E}-03 \\
1.32 \mathrm{E}-03 \\
1.06 \mathrm{E}-03 \\
1.32 \mathrm{E}-03 \\
1.86 \mathrm{E}-03 \\
2.04 \mathrm{E}-03 \\
5.37 \mathrm{E}-03 \\
2.63 \mathrm{E}-03 \\
3.07 \mathrm{E}-03 \\
9.61 \mathrm{E}-04 \\
9.94 \mathrm{E}-04 \\
1.94 \mathrm{E}-03 \\
5.18 \mathrm{E}-03 \\
2.95 \mathrm{E}-03 \\
1.07 \mathrm{E}+00 \\
1.78 \mathrm{E}-03 \\
9.56 \mathrm{E}-04\end{array}$ & $\begin{array}{l}0.129 \\
0.023 \\
0.006 \\
0.002 \\
0.013 \\
0.012 \\
0.002 \\
0.004 \\
0.002 \\
0.006 \\
0.002 \\
0.005 \\
0.002 \\
0.004 \\
0.008 \\
0.004 \\
0.001 \\
0.000 \\
0.000 \\
0.000 \\
0.000 \\
0.000 \\
0.000 \\
0.000 \\
0.001 \\
0.000 \\
0.000 \\
0.000 \\
0.000 \\
0.000 \\
0.000 \\
0.000 \\
0.105 \\
0.000 \\
0.000\end{array}$ & $\begin{array}{l}0.109 \\
0.019 \\
0.005 \\
0.002 \\
0.011 \\
0.010 \\
0.002 \\
0.003 \\
0.002 \\
0.005 \\
0.001 \\
0.004 \\
0.001 \\
0.003 \\
0.007 \\
0.003 \\
0.001 \\
0.000 \\
0.000 \\
0.000 \\
0.000 \\
0.000 \\
0.000 \\
0.000 \\
0.000 \\
0.000 \\
0.000 \\
0.000 \\
0.000 \\
0.000 \\
0.000 \\
0.000 \\
0.087 \\
0.000 \\
0.000\end{array}$ & $\begin{array}{r}14.144 \\
2.514 \\
0.658 \\
0.272 \\
1.449 \\
1.302 \\
0.260 \\
0.389 \\
0.265 \\
0.700 \\
0.186 \\
0.506 \\
0.190 \\
0.423 \\
0.896 \\
0.436 \\
0.115 \\
0.031 \\
0.027 \\
0.014 \\
0.012 \\
0.014 \\
0.021 \\
0.022 \\
0.057 \\
0.029 \\
0.034 \\
0.010 \\
0.011 \\
0.021 \\
0.054 \\
0.033 \\
11.389 \\
0.021 \\
0.010\end{array}$ \\
\hline$\Sigma$ & 0.0459 & 3.46 & 0.334 & 0.281 & 36.5 \\
\hline
\end{tabular}
(a) Release data from Cummins, Hetrick and Martin, 1991
(b) CEDE = committed effective dose equivalent
(c) Average Ind = dose from average consumption at maximum location
(d) EDC = environmental dose commitment
na. $=$ No analyses for this radionuclide until 1971 
Table 6-5. Ofrsite Doses From Stream Releases of ${ }^{13} \mathrm{Cs}$ and ${ }^{137} \mathrm{Cs}$ (Release Data Corrected for Streambed Deposition)

\begin{tabular}{|c|c|c|c|c|c|c|c|c|c|c|}
\hline & \multirow{2}{*}{$\begin{array}{l}\text { Corrected } \\
\text { Release } \\
\text { Ci/yr }(\mathbf{a}, \mathbf{b})\end{array}$} & \multirow{2}{*}{$\begin{array}{l}\text { River } \\
\text { Flow } \\
\text { Rate @ } \\
\text { 301 } \\
\text { (cfs) (a) }\end{array}$} & \multirow{2}{*}{$\begin{array}{l}\text { B-J } \\
\text { Derived } \\
\text { Flow } \\
\text { Rate } \\
(\mathbf{c f s})(\mathbf{a})(\mathbf{c})\end{array}$} & \multirow{2}{*}{$\begin{array}{l}\text { PW } \\
\text { Derived } \\
\text { Flow } \\
\text { Rate } \\
\text { (cfs) (a) }\end{array}$} & \multicolumn{3}{|c|}{$\begin{array}{l}\text { Max Ind Dose, mrem } \\
\text { (d) }\end{array}$} & \multicolumn{2}{|c|}{$\begin{array}{l}\text { WTP Pop Dose, } \\
\text { person-rem }\end{array}$} & \multirow{2}{*}{$\begin{array}{l}\text { Total } \\
\text { Pop } \\
\text { Dose, } \\
\text { Person- } \\
\text { rem (g) }\end{array}$} \\
\hline & & & & & $\begin{array}{l}\text { Below } \\
\text { (e) } \\
\text { SRS }\end{array}$ & $\begin{array}{l}\text { B-J } \\
\text { (I) } \\
\text { WTP }\end{array}$ & $\begin{array}{l}\text { PW } \\
\text { (f) } \\
\text { WTP }\end{array}$ & $\begin{array}{l}\text { B-J } \\
\text { (I) } \\
\text { WTP }\end{array}$ & $\begin{array}{l}\text { PW } \\
\text { (I) } \\
\text { WTP }\end{array}$ & \\
\hline $\begin{array}{l}1955 \\
1956 \\
1957 \\
1958 \\
1959 \\
1960 \\
1961 \\
1962 \\
1963 \\
1964 \\
1965 \\
1966 \\
1967 \\
1968 \\
1969 \\
1970 \\
1971 \\
1972 \\
1973 \\
1974 \\
1975 \\
1976 \\
1977 \\
1978 \\
1979 \\
1980 \\
1981 \\
1982 \\
1983 \\
1984 \\
1985 \\
1986 \\
1987 \\
1988 \\
1989\end{array}$ & $\begin{array}{l}2.35 \mathrm{E}-01 \\
6.36 \mathrm{E}-01 \\
1.73 \mathrm{E}+01 \\
1.13 \mathrm{E}+00 \\
2.78 \mathrm{E}+00 \\
1.22 \mathrm{E}+01 \\
6.63 \mathrm{E}+00 \\
1.31 \mathrm{E}+01 \\
3.41 \mathrm{E}+01 \\
3.80 \mathrm{E}+01 \\
1.18 \mathrm{E}+01 \\
1.28 \mathrm{E}+01 \\
2.76 \mathrm{E}+01 \\
1.52 \mathrm{E}+01 \\
7.68 \mathrm{E}+00 \\
7.44 \mathrm{E}+00 \\
1.07 \mathrm{E}+00 \\
4.56 \mathrm{E}-01 \\
3.21 \mathrm{E}-01 \\
5.25 \mathrm{E}-01 \\
2.66 \mathrm{E}-01 \\
1.06 \mathrm{E}-01 \\
1.78 \mathrm{E}-01 \\
7.49 \mathrm{E}-02 \\
7.42 \mathrm{E}-02 \\
5.62 \mathrm{E}-02 \\
7.79 \mathrm{E}-02 \\
5.62 \mathrm{E}-02 \\
5.07 \mathrm{E}-02 \\
8.34 \mathrm{E}-02 \\
3.46 \mathrm{E}-02 \\
3.68 \mathrm{E}-02 \\
1.33 \mathrm{E}-01 \\
1.97 \mathrm{E}-01 \\
7.21 \mathrm{E}-02\end{array}$ & $\begin{array}{l}5974 \\
6309 \\
8312 \\
11038 \\
9748 \\
13112 \\
10909 \\
10580 \\
11138 \\
20497 \\
12785 \\
11175 \\
10573 \\
9624 \\
10945 \\
8208 \\
10686 \\
11235 \\
14431 \\
11101 \\
15408 \\
13914 \\
11646 \\
10522 \\
13252 \\
13202 \\
6599 \\
7169 \\
12348 \\
12759 \\
7167 \\
6175 \\
8955 \\
5364 \\
7832\end{array}$ & 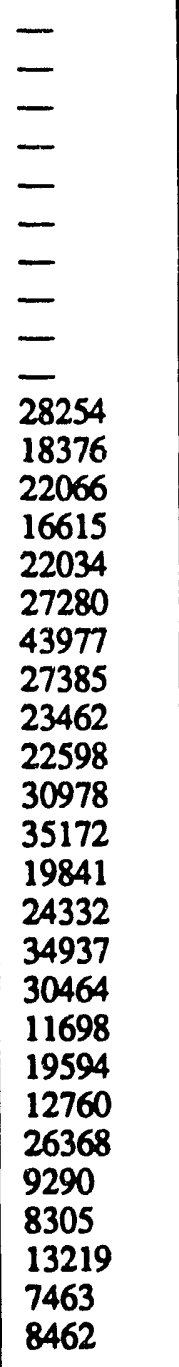 & $\begin{array}{l}7528 \\
7949 \\
10473 \\
13908 \\
12283 \\
16521 \\
13745 \\
13331 \\
14034 \\
25826 \\
16109 \\
14080 \\
13322 \\
12126 \\
13790 \\
10342 \\
13464 \\
14156 \\
16544 \\
13182 \\
18987 \\
16660 \\
15306 \\
11450 \\
17469 \\
17219 \\
8579 \\
10135 \\
14723 \\
17196 \\
8959 \\
7526 \\
12619 \\
7152 \\
8650\end{array}$ & $\begin{array}{l}0.128 \\
0.329 \\
6.766 \\
0.333 \\
0.929 \\
3.027 \\
1.981 \\
4.052 \\
9.968 \\
6.039 \\
3.019 \\
3.743 \\
8.511 \\
5.150 \\
2.287 \\
2.954 \\
0.327 \\
0.132 \\
0.072 \\
0.154 \\
0.056 \\
0.025 \\
0.050 \\
0.023 \\
0.018 \\
0.014 \\
0.038 \\
0.026 \\
0.013 \\
0.021 \\
0.016 \\
0.019 \\
0.048 \\
0.120 \\
0.035\end{array}$ & $\begin{array}{l}\bar{z} \\
\bar{z} \\
\bar{z} \\
\bar{z} \\
\bar{Z} \\
\overline{-} \\
0.017 \\
0.028 \\
0.051 \\
0.037 \\
0.014 \\
0.011 \\
0.001 \\
0.001 \\
0.001 \\
0.001 \\
0.000 \\
0.000 \\
0.000 \\
0.000 \\
0.000 \\
0.000 \\
0.000 \\
0.000 \\
0.000 \\
0.000 \\
0.000 \\
0.000 \\
0.000 \\
0.001 \\
0.000\end{array}$ & $\begin{array}{l}0.001 \\
0.003 \\
0.067 \\
0.003 \\
0.009 \\
0.030 \\
0.020 \\
0.040 \\
0.099 \\
0.060 \\
0.030 \\
0.037 \\
0.085 \\
0.051 \\
0.023 \\
0.029 \\
0.003 \\
0.001 \\
0.001 \\
0.002 \\
0.001 \\
0.000 \\
0.000 \\
0.000 \\
0.000 \\
0.000 \\
0.000 \\
0.000 \\
0.000 \\
0.000 \\
0.000 \\
0.000 \\
0.000 \\
0.001 \\
0.000\end{array}$ & $\begin{array}{l}\bar{Z} \\
\bar{Z} \\
\bar{Z} \\
\overline{-} \\
\overline{-} \\
\overline{-} \\
\overline{0.394} \\
0.656 \\
1.175 \\
0.859 \\
0.327 \\
0.256 \\
0.023 \\
0.016 \\
0.013 \\
0.022 \\
0.008 \\
0.003 \\
0.008 \\
0.003 \\
0.002 \\
0.002 \\
0.006 \\
0.003 \\
0.004 \\
0.003 \\
0.004 \\
0.004 \\
0.009 \\
0.025 \\
0.008\end{array}$ & $\begin{array}{l}0.010 \\
0.025 \\
0.511 \\
0.025 \\
0.070 \\
0.228 \\
0.150 \\
0.306 \\
0.752 \\
0.456 \\
0.228 \\
0.282 \\
0.642 \\
0.389 \\
0.173 \\
0.223 \\
0.025 \\
0.010 \\
0.006 \\
0.012 \\
0.004 \\
0.002 \\
0.004 \\
0.002 \\
0.001 \\
0.001 \\
0.003 \\
0.002 \\
0.001 \\
0.002 \\
0.001 \\
0.002 \\
0.003 \\
0.009 \\
0.003\end{array}$ & $\begin{array}{l}0.256 \\
0.657 \\
13.500 \\
0.665 \\
1.860 \\
6.050 \\
3.960 \\
8.100 \\
19.900 \\
12.100 \\
6.450 \\
8.130 \\
18.200 \\
11.100 \\
4.900 \\
6.160 \\
0.675 \\
0.280 \\
0.158 \\
0.330 \\
0.120 \\
0.053 \\
0.108 \\
0.050 \\
0.038 \\
0.029 \\
0.083 \\
0.054 \\
0.031 \\
0.045 \\
0.035 \\
0.043 \\
0.106 \\
0.264 \\
0.078\end{array}$ \\
\hline $\boldsymbol{\Sigma}$ & 212 & 10297 & 21797 & 13296 & 60.4 & 0.16 & 0.60 & 3.83 & 4.56 & 125 \\
\hline
\end{tabular}

(a) Original release dats from Cummins, Hetrick and Martin, 1991. Flow rates based on USGS data at Highway 301 for the maximum individual below the Site. All other doses calculated from flow rates derived from tritum data.

(b) Stream releases corrected for onsite deposition (see Chapter 4 text).

(c) The Beaufort-Jasper water treatment plant began operation in 1965.

(d) Individual doses are committed effective dose equivalents (CEDEs)

(e) Includes contribution from fish and invertebrate consumption, shoreline habitation, secreational use, and water consumption

(f) WTP doses calculated for water consumption only.

(g) Population doses are committed effective dose equivalents (CEDEs) 


\section{References}

Bauer, L. R., 1991,"Modeling Chronic Atmospheric Releases at the SRS: Evaluation and Verification of XOQDOQ(U)", WSRC-RP-91-320, Westinghouse Savannah River Company, Aiken, SC.

BEIR, 1980, "Health Effects of Exposure to Low Levels of Ionizing Radiation - BEIR III", Commituee on the Biological Effects of lonizing Radiations, Board of Radiation Effects Research, Commission on Life Sciences, National Research Council, National Academy of Sciences.

BEIR, 1990, "Health Effects of Exposure to Low Levels of Ionizing Radiation - BEIR V", Committee on the Biological Effects of lonizing Radiations, Board of Radiation Effects Research, Commission on Life Sciences, National Research Council, National Academy of Sciences.

Cooper, R. E., 1975, “Computer Programs at SRL to Evaluate Environmental Effects of SRP Operations and Postulated Accidental Releases", DPST-75-384, Savannah River Laboratory, Aiken, SC.

Cummins, C. L., D. K. Martin, and J. L. Todd, 1990a, "Savannah River Site Environmental Report for 1989", WSRC-IM-90-60, Vol. II: Westinghouse Savannah River Company, Aiken, SC, p. 96.

Cummins, C. L., D. K. Martin, and J. L. Todd, 1990b, "Savannah River Site Environmental Report for 1989", WSRC-IM-90-60, Westinghouse Savannah River Company, Aiken, SC, p. Xv.

DOE (U.S. Department of Energy), 1988, "Internal Dose Conversion Factors for Calculation of Dose to the Public", DOE/EH-0071, Washington, DC.

DOE, 1990. "Radiation Protection of the Public and the Environment", DOE Order 5400.5, U.S. Department of Energy, Washington, DC.

Eckerman, K. F., F. J. Congel, A. K. Roecklein and W. J. Pasciak, 1980, "User's Guide to GASPAR Code", NUREG-0597, U.S. Nuclear Regulatory Commission, Washington, DC.

EPA (U.S. Environmental Protection Agency), 1977, “National Interim Primary Drinking Water Regulations", EPA 570/9-76-003, Washington, DC.

EPA, 1988, "Limiting Values of Radionuclide Intake and Air Concentration". EPA 520/1-88-020, Washington, DC.

EPA, 1989a, "Environmental Impact Statement NESHAPS for Radionuclides - Risk Assessment Methodology", Volume 1, EPA 520/1-89-005, Washington, DC.

EPA, 1989b,40 CFR Part 61, "National Emission Standards for Hazardous Air Pollutants; Regulation of
Radionuclides; Final Rule and Notice of Reconsideration", Federal Register, Vol. 54, No. 240.

Hamby, D. M., 1991, "Land and Water Use Characteristics in the Vicinity of the Savannah River Site (U)", WSRC-RP-91-17, Westinghouse Savannah River Company, Aiken, SC.

Hamby, D. M., and M. J. Parker, 1991, "Gaussian Dispersion and Dosimetric Modeling Sensitivity to AreaSpecific 1982-1986 Meteorological Data Collected at the Savannah River Site (U)", WSRC-RP-91-909.

ICRP (Intemational Commission on Radiological Protection), 1979, "Limits for Intake of Radionuclides by Workers", ICRP Publication 30, Part 1, Annals of the ICRP.

ICRP, 1989, "Age-Dependent Doses to Members of the Public from Radionuclides", ICRP Publication 56, Annuals of the ICRP.

ICRP, 1991, Risks Associated with lonizing Radiations, Vol. 22, No. 1, Annals of the ICRP.

Marter, W.L., 1984, "Environmental Dosimetry for Normal Operations at SRP", DPST-83-270, Rev. 1, Savannah River Laboratory, Aiken, SC.

NAS (National Academy of Sciences), 1980, "The Effects on Populations of Exposure to Low Levels of Ionizing Radiation", Washington, DC.

NCRP (National Council on Radiological Protection and Measurements), 1987, "Recommendations on Limits for lonizing Radiation Exposure", NCRP Report No. 91, Washington, DC.

NRC (U.S. Nuclear Regulatory Commission), 1977a, "Methods for Estimating Aumospheric Transport and Dispersion of Gaseous Effluents in Routine Releases from Light-Water-Cooled Reactors", Regulatory Guide 1.111, Rev. 1, Washington, DC.

NRC, 1977b. "Calculation of Annual Doses to Man from Routine Releases of Reactor Effluents for the Purpose of Evaluating Compliance with 10 CFR Par 50, Appendix $I^{m}$, Regulatory Guioe 1.109, Rev. 1, Washington, DC.

Sagendorf, J. F., J. T. Goll, and W. F. Sandusky, 19\&2, "XOQDOQ: Computer Program for the Meteorological Evaluation of Routine Effluent Releases at Nuclear Power Stations", NUREG/CR-2919, U.S. Nuclear Regulatory Commission, Washington, DC.

Simpson, D. B., and B. L. McGill, 1980, "Users Manual for LADTAP II - A Computer Program for Calculating Radiation Exposure to Man from Routine Releases of Nuclear Reactor Effluents", NUREG/CR-1276, ORNL/TDMC-1, Oak Ridge National Laboratory, Oak Ridge, TN. 


\section{Appendix 1. Physical Properties of Cesium}

The element cesium has only one isotope that is not radioactive $\left({ }^{33} \mathrm{Cs}\right)$. Fourteen radioactive isotopes of cesium may be present at Savannah River Site (SRS) due to site operations. Each isotope's half-life and primary source at SRS are tabulated in Table A1-1. Half-lives range from seconds to millions of years. The isotopes can be present at SRS from two sources - as fission products from fission nuclear reactions and as activation products from either neutron capture or $(n, 2 n)$ nuclear reactions.

Some of the isotopes may exist both in their lowest energy level and in an excited energy level if this excited level does not have a very short half-life. In the latter case the isotope designation includes the letter " $\mathrm{m}$ " to indicate a metastable level: for example, ${ }^{135 \mathrm{C}} \mathrm{Cs}$ indicates that ${ }^{135} \mathrm{Cs}$ exists in an excited energy level.

The isotope ${ }^{137} \mathrm{Cs}$ has the greatest impact on the SRS environment.

Table A1-1. Characteristics of Radioactive Cesium Isotopes That May Be Present at SRS Due To Site Operations.

$\begin{array}{lll}\text { Cesium Isotope } & \text { Primary Source } & \text { Half Life } \\ { }^{131} \mathrm{Cs} & \text { AP } & 9.7 \text { days } \\ { }^{132} \mathrm{Cs} & \text { AP } & 6.6 \text { days } \\ { }^{13} \mathrm{Cs} & \text { AP } & 2.1 \text { years } \\ { }^{136} \mathrm{Cs} & \text { AP } & 2.9 \text { hours } \\ { }^{130} \mathrm{Cs} & \text { FP } & 2.3 \times 10^{6} \text { years } \\ { }^{1350} \mathrm{Cs} & \text { AP } & 53 \text { minutes } \\ { }^{136} \mathrm{Cs} & \text { AP } & 13 \text { days } \\ { }^{13} \mathrm{Cs} & \text { FP } & 30 \text { years } \\ { }^{130} \mathrm{Cs} & \text { FP } & 32 \text { min } \\ { }^{130} \mathrm{Cs} & \text { FP } & 9.3 \text { min } \\ { }^{100} \mathrm{Cs} & \text { FP } & 66 \text { seconds } \\ { }^{101} \mathrm{Cs} & \text { FP } & 25 \text { seconds } \\ { }^{112} \mathrm{Cs} & \text { FP } & 1.8 \text { seconds } \\ { }^{143} \mathrm{Cs} & \text { FP } & 1.8 \text { seconds } \\ { }^{140} \mathrm{Cs} & \text { FP } & 1.0 \text { seconds }\end{array}$

$\mathrm{AP}=$ activation product; $\mathrm{FP}=$ fission product. 
Appendix 2.

Environmental Monitoring 


\section{Air}

Concentrations of ${ }^{137} \mathrm{Cs}$ in the air are measured at 5 monitoring stations on the site, 14 monitoring stations around the site perimeter, and 12 stations at distances of approximately $40 \mathrm{~km}$ from the center of the site. The stations at the site perimeter and the $40-\mathrm{km}$ stations are strategically located to permit continuous sampling within each 30-degree sector around Savannah River Site. The placement of each monitoring station increases the probability of detecting any routine or nonroutine release of airborne radioactivity from the Savannah River Site regardless of wind direction. Figure A2-1 shows the locations of the monitoring stations.

Additional air monitoring stations located at Savannah and Macon, Georgia, and at Columbia and Greenville, South Carolina (155-km stations), are so distant from SRS that the effect of SRS operations at these locations is negligible. These stations serve as reference points for determining background radioactivity levels from natural sources and from world-wide fallout. Samplers operate continuously at all 35 monitoring stations. Samples for ${ }^{17} \mathrm{Cs}$ are collected by drawing air through a 2-in. diameter, high-efficiency paper filter at approximately $70 \mathrm{~L} / \mathrm{mi}$. $(2.5 \mathrm{cfm})$. The filters, located upstream from the charcoal cartridges, are changed weekly. Figure A2-2 is a diagram of an air sampling station. The isotope ${ }^{15} \mathrm{Cs}$ is measured by direct count of the filter on

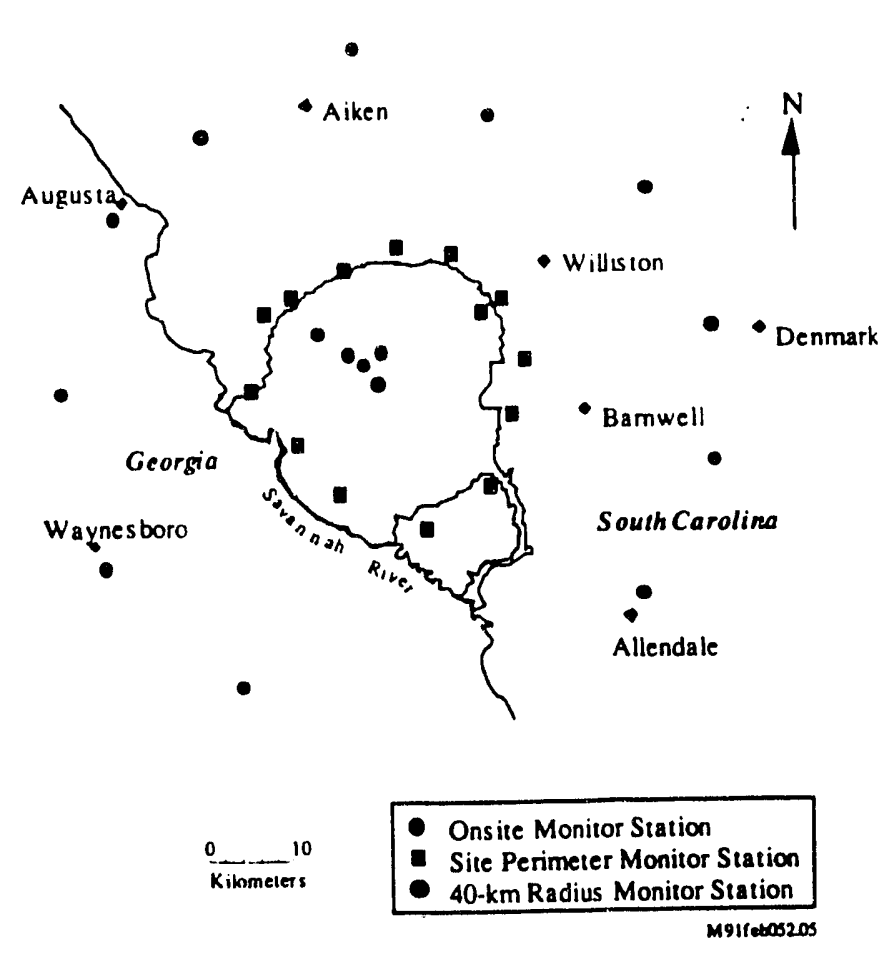

Ftgure A2-1. Location of Air Monitoring Stations

an HPGe detector which accurately distinguishes ${ }^{137} \mathrm{Cs}$ from other radionuclides using the HPGe detector's high spectral resolution. Counting time is $\mathbf{5 0 0 0}$ seconds. 

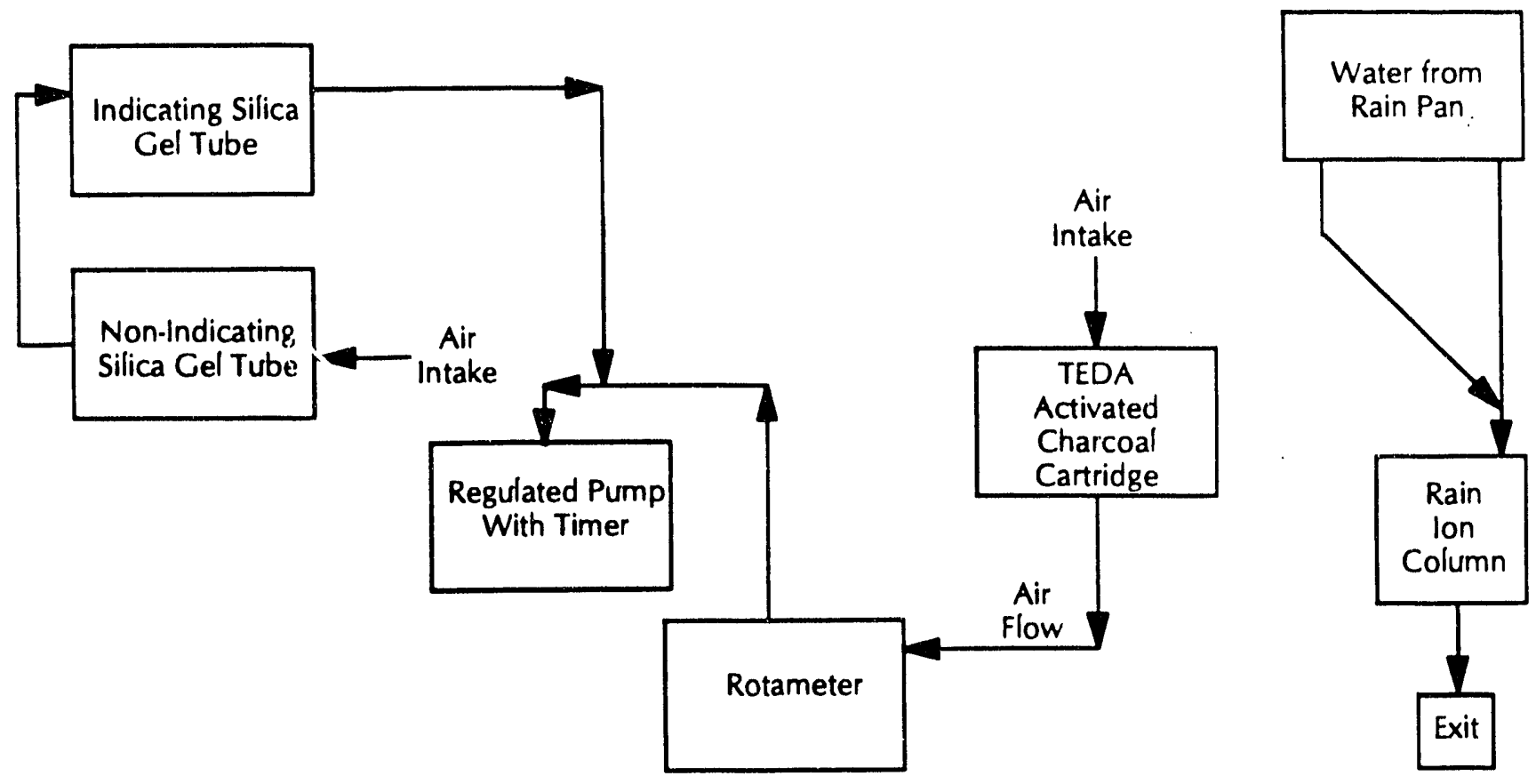

Figure A2-2. Air Sampling Station and Component Diagram 


\section{Rainwäter}

Rainwater is also collected at all 35 monitoring stations by a 2-in.-by-2-in. collection pan. At 8 stations, the collected water passes through an ion exchange resin column and then into a collection bottle. At the remainder of the stations, the water passes directly into the collection bottle. The ion columns are collected every fourth week except for the 155-km stations which are collected once a quarter. Rain in the sample botules is not analyzed for cesium except in special cases. The samples are analyzed by counting the resin column on a high resolution gamma spectrometer for at least 3000 seconds. 


\section{Surface Water}

Surface water cesium concentrations are determined by laboratory analysis of samples. Three types of liquid samples are routinely collected for cesium analysis:

\section{Effluent Outfalls \\ 2. Streams \\ 3. Savannah River}

\section{Effluent Outfalls}

Samples are collected where effluents discharge into surface water. Samples are generally not collected fro: : the actual physical outfall where the pipe discharges, but are usually collected downstream of the outfall in a canal or drainage ditch, which carries the effluent from that outfall to a body of surface water.

Various types of composite samplers are used. The primary samplers are the paddlewheel sampler or the Brailsford pump sampler. Generally, routine samples are collected weekly and analyzed for cesium by counting a 1 -liter aliquot on a high resolution gamma spectrometer for at least 3000 seconds.

\section{Site Streams}

The major streams on site are routinely sampled:

- Upper Three Runs

- Lower Three Runs

- Four Mile Creek

- Steel Creek

- Pen Branch

\section{- Beaver Dam Creek}

Generally, routine stream samples are collected weekly with a paddlewheel or Brailsford pump. Samples are analyzed for cesium by counting a 1-liter aliquot on a high resolution gamma spectrometer for at least 3000 seconds.

\section{Savannah River}

The Savannah River receives the outflow from all streams located on SRS and is the most critical sample location for determining population dose from SRS operations.

The Savannah River is sampled in eight locations (see Figure A2-3):

1. R-2 above SRS

2. R-3A above Plant Vogtle

3. R-3B below Plant Vogtle

4. R-8A Steel Creek Landing

5. R-8B Steel Creek Landing

6. R-8C Little Hell Landing

7. R-10A Highway 301 Bridge

8. R-1OB Highway 301 Bridge

Samples are collected by a continuous (paddlewheel) sampler and are picked up weekly. In addition, a grab sample is collected each week at R-2.

River samples are analyzed for cesium by passing a large volume of water through an ion exchange resin column which strips out the cesium (as well other fission products). The resin column is then counted on a high resolution gamma spectrometer for at least 3000 seconds. 


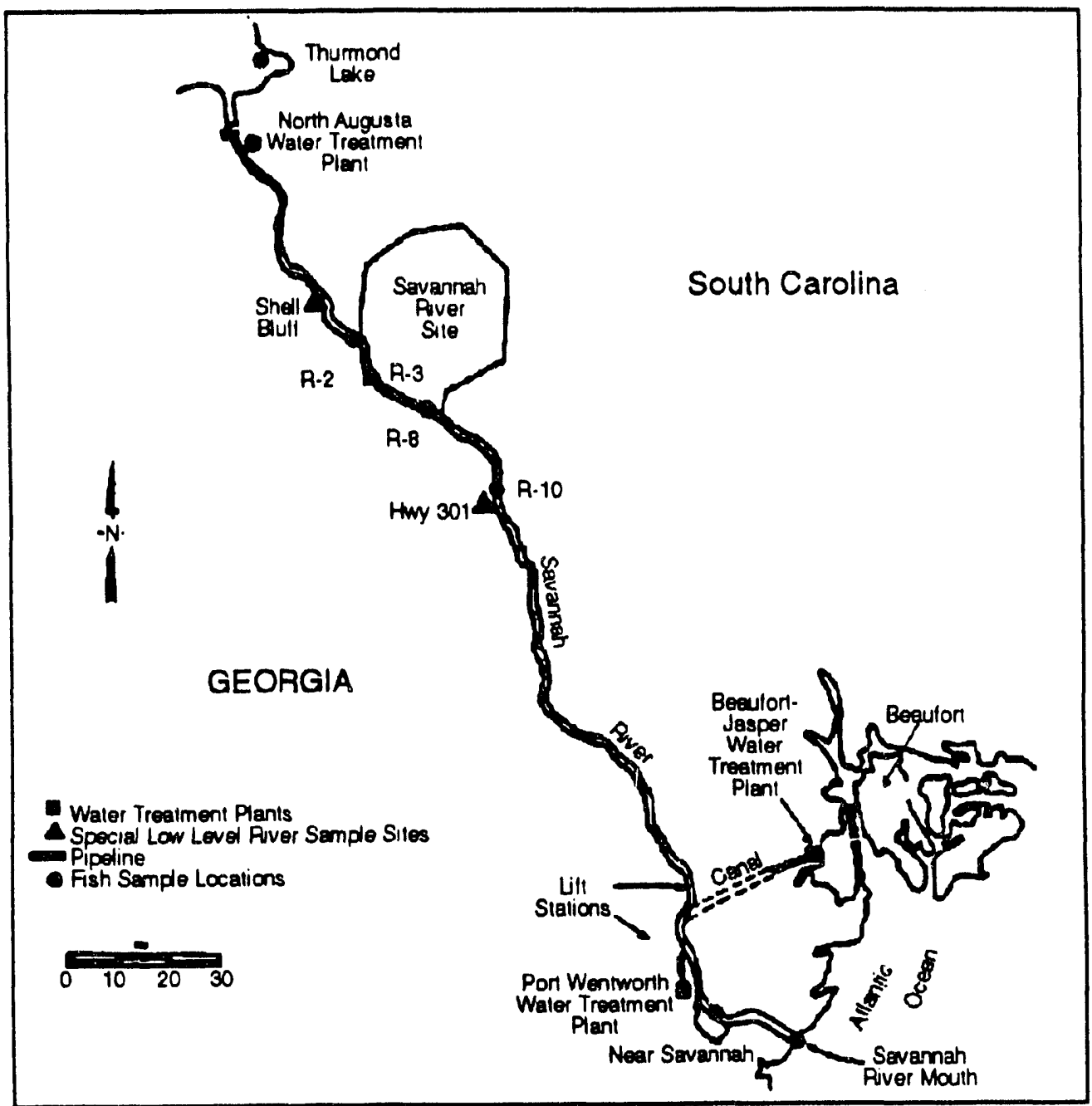

Figure A2-3. Fish Sample and Water Treatment Plant Locations along the Savannah River 


\section{Groundwater}

The Environmental Monitoring Section conducts a routine groundwater monitoring program. Radioactive and nonradicactive monitoring programs are carried out for approximately 1200 wells. The radioactive monitoring program began in the early 1950 s and has primarily monitored for gross alpha, nonvolatile beta, and tritum activities. The nonradioactive monitoring program began in 1982 and gross alpha, nonvolatile beta, total radium, and tritium activities are also monitored at wells in this program. All wells are analyzed for gross alpha, nonvolatile beta, tritium, and total radium biannually, and all new wells are analyzed for these parameters for four consecutive quarters. Special studies are periodically conducted by the Savannah River Laboratory.

Analytical results are reported in quarterly groundwater reports and in the annual SRS Environmental Report. A documented database is maintained for all groundwater data collected by Environmental Monitoring Section. This database can be queried to produce graphs and tables for reports or research projects. 